\title{
Covenant Violations and Dynamic Loan Contracting
}

\author{
Freudenberg, Felix; Imbierowicz, Björn; Saunders, Anthony; Steffen, Sascha
}

Document Version

Accepted author manuscript

Published in:

Journal of Corporate Finance

DOI:

10.1016/j.jcorpfin.2017.05.009

Publication date:

2017

License

CC BY-NC-ND

Citation for published version (APA):

Freudenberg, F., Imbierowicz, B., Saunders, A., \& Steffen, S. (2017). Covenant Violations and Dynamic Loan Contracting. Journal of Corporate Finance, 45, 540-565. https://doi.org/10.1016/j.jcorpfin.2017.05.009

Link to publication in CBS Research Portal

\section{General rights}

Copyright and moral rights for the publications made accessible in the public portal are retained by the authors and/or other copyright owners and it is a condition of accessing publications that users recognise and abide by the legal requirements associated with these rights.

Take down policy

If you believe that this document breaches copyright please contact us (research.lib@cbs.dk) providing details, and we will remove access to the work immediately and investigate your claim. 


\title{
Covenant Violations and Dynamic Loan Contracting
}

Felix Freudenberg, Björn Imbierowicz, Anthony Saunders, and Sascha Steffen

Journal article (Accepted manuscript*)

\author{
Please cite this article as: \\ Freudenberg, F., Imbierowicz, B., Saunders, A., \& Steffen, S. (2017). Covenant \\ Violations and Dynamic Loan Contracting. Journal of Corporate Finance, 45, 540-565. \\ DOl: 10.1016/j.jcorpfin.2017.05.009 \\ DOI: 10.1016/j.jcorpfin.2017.05.009
}

* This version of the article has been accepted for publication and undergone full peer review but has not been through the copyediting, typesetting, pagination and proofreading process, which may lead to differences between this version and the publisher's final version AKA Version of Record.

Uploaded to CBS Research Portal: February 2019

(C) 2019. This manuscript version is made available under the CL-BY-NC-ND 4.0 license

http://creativecommons.org/licenses/by-nc-nd/4.0/ 


\title{
Covenant Violations and Dynamic Loan Contracting
}

\author{
Felix Freudenberg $_{\dagger} \quad$ Björn Imbierowicz ${ }^{\ddagger}$ Anthony Saunders* Sascha Steffen ${ }^{\S}$
}

\begin{abstract}
This paper examines the dynamic allocation of control rights in private debt contracts of firms. We show that a covenant violation in the prior loan contract implies a stigma for borrowers which results in stricter loan contract terms in subsequent new loan contracts. Our analyses reject potentially other explanations such as firm characteristics or agency problems between the lender and firm management, shareholders or public debtholders. After covenant violations in the prior contract, new loans have on average 18bps higher spreads and include more of those covenant types which also have been violated in the prior contract, with tighter thresholds.
\end{abstract}

JEL Classification: G21, G32, L14.

Keywords: $\quad$ Control Rights, Covenant Violation, Dynamic Loan Contracting, Stigma.

We thank Heitor Almeida, Thorsten Beck, Tobias Berg, Allen Berger, Lamont Black, Sapnoti Eswar, Jens Hagendorff, Paul Heidhues, Martin Hibbeln, Mark Humphery-Jenner, Vasso Ioannidou, Jan Krahnen, Simon Kwan, Bart Lambrecht, Christian Leuz, Ulrike Malmendier, Justin Murfin, Greg Nini, Michael Roberts, Jörg Rocholl, Raluca Roman, Catalina Stefanescu-Cuntze, Gregory Udell, Mark Wahrenburg, Andrew Winton, Robert DeYoung and participants at the Bank Structure Conference in Chicago, the American Finance Association Meetings in San Diego, the Financial Intermediation Research Society Conference in Dubrovnik, the European Finance Association Meetings in Copenhagen, the NYU Corporate Governance Seminar in New York, the Financial Management Association European Conference in Luxembourg, the Campus for Finance in Vallendar, the Brown Bag Seminar in Frankfurt, the Financial Management Association Meetings in Chicago, and the Workshop on Banking and Finance in Münster. Björn Imbierowicz gratefully acknowledges financial support from the Fritz Thyssen Foundation, and the Center for Financial Frictions (FRIC), grant no. DNRF102.

$\dagger$ Goethe University Frankfurt. Email: felix.freudenberg@hof.uni-frankfurt.de. Tel: +49 6979833700.

+ Corresponding author: Copenhagen Business School, Finance Department and Center for Financial Frictions (FRIC), 2000 Frederiksberg (Denmark). Email: bi.fi@cbs.dk. Tel: +453815 3736.

* New York University, Stern School of Business. Email: asaunder@ stern.nyu.edu. Tel: +1 2129980711.

$\S$ University of Mannheim and ZEW. Email: steffen@zew.de. Tel: +49 30212311544. 


\title{
Covenant Violations and Dynamic Loan Contracting
}

\begin{abstract}
This paper examines the dynamic allocation of control rights in private debt contracts of firms. We show that a covenant violation in the prior loan contract implies a stigma for borrowers which results in stricter loan contract terms in subsequent new loan contracts. Our analyses reject potentially other explanations such as firm characteristics or agency problems between the lender and firm management, shareholders or public debtholders. After covenant violations in the prior contract, new loans have on average 18bps higher spreads and include more of those covenant types which also have been violated in the prior contract, with tighter thresholds.
\end{abstract}

JEL Classification: G21, G32, L14.

Keywords: $\quad$ Control Rights, Covenant Violation, Dynamic Loan Contracting, Stigma. 


\section{Introduction}

The literature on incomplete contracts argues that for firm value maximization control should be balanced between the entrepreneur and the investor and cash flow rights and control rights should be correlated (Aghion and Bolton, 1992; Dewatripont and Tirole, 1994). Accordingly, control should be allocated to investors with a concave cash flow claim (such as debt) in low profitability states and in high profitability states to investors with a convex cash flow claim (such as equity). Specifically, loans with financial covenants allow for shifts in control to lenders in bad states. This improves ex ante managerial incentives and maximizes firm value (Zender, 1991; Aghion et al., 1994; Dewatripont and Tirole, 1994; Berglöf and von Thadden, 1994). ${ }^{1}$ Moreover, an increased scope for renegotiation increases contracting efficiency and minimizes opportunistic behavior (Christensen et al., 2015). In our study, we investigate empirically if a covenant violation is a signal from the prior loan contract which induces lenders to act as "tough principals" in the subsequent new loan by increasing the scope for renegotiation (e.g.; Huberman and Kahn, 1988; Aghion et al., 1994; Dewatripont and Tirole, 1994; Li, Vasvari and Wittenberg-Moerman 2015). Importantly, we argue that a covenant violation affects loan contract terms in addition to borrower characteristics at the origination of the new loan and is also not related to hold-up of borrowers by particular lenders. A covenant violation implies a stigma for borrowers.

A covenant violation is in most cases related to borrower credit risk at the time of violation. However, their impact on new loans, which are initiated at a very different point in time, is much less clear. Recent findings in the literature show that borrower characteristics substantially improve after a covenant violation. In the period after a violation borrowers reduce acquisitions and investments, do not assume further leverage and decrease shareholder payouts, risk shifting is limited and corporate governance improved (Chava and Roberts, 2008; Roberts and Sufi, 2009a, b; Nini et al., 2009, 2012). Thus, while firm risk is clearly elevated at the time of the covenant violation it decreases back towards "regular" levels over the year following the violation. ${ }^{2}$

\footnotetext{
${ }^{1}$ The existence of covenants increases the availability of credit (Stiglitz and Weiss, 1983; Diamond, 1984; Besanko and Kanatas, 1993). Covenants act as a tripwire mechanism, which immediately shifts control rights from borrowers back to lenders once they are violated (Jensen and Meckling, 1976; Smith and Warner, 1979; Aghion and Bolton, 1992; Berlin and Mester, 1992).

${ }^{2}$ Note that the time period between a covenant violation and the initiation of a subsequent new contract is substantial. Our data show that new loans subsequent to a covenant violation are originated, on average, 1,091 days after a violation.
} 
The contract terms of a new loan are also unlikely to reflect the outcome of the last renegotiation round of the previous loan. Denis and Wang (2014) and Roberts (2015) show that the majority of renegotiations does not relate to covenant violation and implies a relaxation of previous restrictions. ${ }^{3}$ Denis and Wang (2014) observe that a tightening of thresholds in renegotiations effectively implies that they are brought back to their original level. Regarding covenant violations, they find that lenders rarely change the covenant limits in case of violations. The authors argue that a violation (instead of a prior renegotiation to avoid this violation) reflects lenders' thorough evaluation of the borrower's characteristics and prospects at this time. In simple words, lenders allow for violations only because borrowers shirk and/or have substantially misevaluated projects and their future performance. Accordingly, a covenant violation is a publicly observable negative signal. This relates to the results on borrower misbehavior and higher default rates in the retail loan market (e.g.; Agarwal et al., 2015; Garmaise, 2015). In our study, we investigate the consequences of misbehavior in a dynamic setup. We hypothesize that the prior covenant violation signal induces lenders to act as tough principals in the subsequent loan such that they implement a "tougher financial structure" in the new loan contract. ${ }^{4}$ More specifically, we expect the loan spread as well as the number and strictness of covenants to increase in a new loan following a covenant violation in the prior loan. We argue that the signal of a covenant violation results in a stigma for the borrower.

Financial covenants are part of virtually all private credit agreements (Leftwich, 1983; Roberts and Sufi, 2009a). As documented in earlier literature, existing data sources such as LPC Dealscan have limitations in keeping a full record of covenants as well as the complexity of covenant structures in loan contracts. We therefore follow Demerjian and Owens (2016) and build our analysis on a novel and handgenerated dynamic data set of individual borrower loans and covenants constructed from original loan contracts identified in borrowers' SEC filings. Our sample comprises 3,813 loans made over the 1996 to 2010 period. ${ }^{5}$ We collect more than 80 different covenant types and definitions from these loan contracts. We also know step-up and step-down provisions for each covenant. We use all the information available to us from these contracts to calculate covenant violations on a quarterly basis. Based on this, we build an indicator variable for covenant violation and match it to the subsequent new loan of the same borrower.

\footnotetext{
${ }^{3}$ Furthermore, Gârlenau and Zwiebel (2009) argue in a theoretical paper that in renegotiations of existing loans covenants typically weaken rather than tighten.

${ }^{4}$ As an example, Dewatripont and Tirole (1994) suggest to for example use more short-term debt. Long-term debt with more and tighter covenants relates to this notion.

5 After applying a large number of filters and after matching these loan contracts to the LPC Dealscan and the merged CRSP/Compustat database.
} 
To measure contract strictness we use covenant information from the 80 covenant types we identify in our data and for each type in each quarter subtract the covenant threshold from the actual value of the financial covenant and normalize its absolute value with the standard deviation of the covenant variable, derived over the previous 12 quarters. Analogous to the "Distance to Default" ("DD") measure that is used to measure a firm's probability of default, this measure that might be viewed as a "Distance to Covenant Violation" or "DCV" measure. Comparable with Prilmeier (2016), the covenant with the lowest DCV of all covenants in a contract is a measure of the contract's distance to covenant violation. In addition, we use the "average distance to covenant violation", which is an index using a simple averaging mechanism over the individual DCVs of all covenants in a contract. The distance to covenant violation represents the distance an accounting-based covenant value/ ratio must deteriorate (in terms of its number of standard deviations) before a covenant threshold is violated. A lower value suggests that covenants are (on average) stricter. Following Bradley and Roberts (2004), we also utilize a Contract Intensity Index that reflects the overall restrictiveness of the loan on the actions of the borrower's management.

We analyze the dynamic allocation of control rights over consecutive private debt contracts of the same borrower, focusing on firms that are recurring borrowers in the syndicated loan market. We know which firms violate covenants and which covenants are violated at any moment in time. We also know how lenders react in any subsequent loan contract, how they set covenant levels and how these differ from prior loan contracts to the same borrower. We find that after covenant violations in the prior loan contract lenders demand higher spreads and also increase the number and tightness of covenants in the following (new) loan contract, consistent with lenders acting as tough principals. This result is robust to unobservable constant borrower characteristics and confirmed in matching models and a regression discontinuity design. We provide several additional tests which show that the tougher financial structure in the new loan is not driven by other factors such as (i) firm credit risk, (ii) disciplining of managers, (iii) hold-up issues or (iv) differences in corporate governance characteristics. This argues for a prior covenant violation being a stigma for borrowers.

We investigate these alternative explanations in detail. Specifically, we investigate the effect of prior covenant violation on the loan contract terms of the new loan between matched firms which only differ in having violated a covenant in the prior loan using propensity score matching as well as a regression discontinuity design. In both setups we find our results confirmed. In addition, we investigate 
borrower credit risk in more detail. We document a continuous decrease of borrower risk (as measured by the probability of default (PD)) after covenant violations. The PD converges to the PD of similar, non-violating borrowers about 800 days after the violation. However, we find that subsequent new loans are originated, on average, 1,091 days after a violation. This suggests that borrowers who did or did not violate covenants in a previous loan exhibit similar default risk based on ex-ante observable characteristics at the time of a subsequent loan origination. Furthermore, we also test if covenant violations predict differences in borrower credit risk over a longterm period incorporating borrower defaults, rating downgrades, changes in net worth and leverage as well as the number of loss-making quarters. These tests confirm that the initially higher risk of violating borrowers dissolves over time.

We also analyze potential managerial agency problems by investigating the contract terms of a subsequent new loan for firms with and without a change in its CEO, also accounting for the reason of the $\mathrm{CEO}$ change, i.e. if, for example, the CEO was forced to resign. Furthermore, we examine if borrowers are "held up" by banks (Sharpe, 1990; Rajan, 1992) differentiating firms by their access to public debt capital markets, an alternative to bank financing. We also test differences in corporate governance using the ownership structure of borrowing firms. None of these alternatives explains the tougher covenant structure in subsequent new loans after covenant violations in the prior contract. In contrast, our results suggest that prior covenant violations are a stigma for the borrower.

In a further set of tests, we explore if the tougher financial structure in the new contract is related to the severity of covenant violation in the prior contract. We hypothesize that lenders tighten contract terms more the worse the covenant violation(s) in the prior loan, that is, there are differences in stigmatization. More specifically, we analyze the impact of the number of violated covenants in the prior loan on the contract terms of the subsequent new loan. We find that lenders are tougher the higher the violation severity of covenants in the prior loan. Covenants become stricter and the loan spread increases more in the new contract when there are a higher number of covenants violated in a prior loan contract.

We are also interested if violations of specific types of financial covenants have a different impact on the contract terms of the subsequent new loan. For this purpose, we classify covenants into profitability-based and capital-based covenants following Christensen and Nikolaev (2012) and further 
refine their covenant classification by distinguishing capital-based covenants into leverage, net worth and short-term covenants. Our results show that irrespective of the type of violated covenants, lenders implement a tougher financial structure in the subsequent new contract and use more and tighter covenants (of the same type as violated before) and charging higher loan spreads.

We then explore the dynamic development of loan contract terms over multiple consecutive new loan contracts to the same borrower as a function of whether or not the borrower violated covenants in the prior loan. Borrowers become less opaque the more frequently they borrow in the syndicated loan market. Interestingly, we document that repeated borrowing (without a covenant violation) has, on average, almost no effect on loan spreads but a sizable effect on non-price terms reflected in fewer and less restrictive covenants. However, importantly, if borrowers violate covenants in a prior loan, lenders increase loan spreads as well as increase the number and tightness of financial covenants in a subsequent new loan, irrespective of the frequency of borrowing new loans. In sum, these findings argue for changes in stigma over time. More violations over more contracts result in a stronger stigma. However, this can also be "cured" by the borrower by good conduct, i.e. not violating covenants in loan contracts.

Finally, we investigate if the changes in the financial structure after covenant violations help to address potential agency and information problems in the subsequent new contract. We therefore analyze the effect of covenant violations on the size and composition of the lending syndicate in the subsequent new loan. Overall, we neither find significant differences in the number of lenders that participate in syndicates of loans to borrowers who did and did not violate a covenant in their prior loan nor on the size of loans provided by each syndicate lender. Moreover, we find that borrowers who violated covenants are neither more nor less likely to switch to new lenders. Thus, it appears that covenant structures and the possibility for lenders to act as tough principals after borrower misconduct help to address information asymmetry and supply side frictions in primary loan markets. Furthermore, it confirms that the tougher financial structure is not related to particular lenders extracting "unfair" rents from the borrower after a covenant violation in the prior contract.

Our paper proceeds as follows. The next section describes how we construct our data set and provides descriptive statistics. Section 3 empirically explores dynamic loan contract design after covenant violations and examines alternative explanations for our findings. Section 4 investigates the severity of covenant violations and the type of covenant violated together with the type of covenant included after 
violations. Section 5 provides an analysis of dynamic loan contracting over multiple consecutive loan contracts of the same borrower followed by results for the supply side of capital. Section 7 concludes.

\section{Data and Descriptive Statistics}

\subsection{Data}

To investigate the effect of covenant violations on subsequent loan contracting, we construct a unique data set collecting original loan contracts directly from the Security and Exchange Commission (SEC) filings of public firms using EDGAR (Electronic Data-Gathering, Analysis and Retrieval). Material loan contracts have to be reported as required by the SEC and can be found as an exhibit to a 10-K, 10-Q or as an attachment to an $8-\mathrm{K}$ filing. By collecting covenant definitions directly from loan contracts we follow the suggestion in Demerjian and Owens (2016) because covenants are frequently customized and might otherwise contain measurement errors (e.g.; Leftwich, 1983; El Gazzar and Pastena, 1990; Beatty et al., 2008). We start with the set of private credit agreements provided by Greg Nini, David Smith and Amir Sufi who collected these contracts over the 1996 to 2005 period and extend this set of contracts for 5 more years until the end of 2010 following their methodology. We add 1,276 loan contracts from EDGAR to the 3,720 contracts from Nini, Smith and Sufi (2009) and apply various filters to these 4,996 credit agreements. We exclude all observations where we cannot identify a contract in Dealscan as well as loans specified as amendments in Dealscan or in the loan contract (Roberts, 2015). In other words, all contracts are new loans.

Private loan agreements typically include positive, negative, and financial covenants. ${ }^{6}$ Negative covenants prevent the borrower from certain actions such as excessive investments, distribution of dividends, sale of assets, changes in company control, entering sale-and-lease-back transactions, or changing business activities. Financial covenants are often termed "performance hurdles" or "tripwires" (e.g.; Smith, 1993; Dichev and Skinner, 2002) due to their ability to shift control rights. Although Dealscan already provides some information on financial covenants, we still find that several covenants

\footnotetext{
${ }^{6}$ We do not include positive covenants such as punctual payment of interest and principal, delivery of financial statements, property and equipment maintenance, compliance to accounting standards, or paying insurance and taxes, as these are often not directly observable, in line with, for example, Bradley and Roberts (2004) and Demiroglu and James (2010). In addition, there exist incurrence covenants which refer to a predetermined event, such as the issuance of new debt or the acquisition of another company.
} 
are missing. Furthermore, the definition of seemingly similar covenants differs substantially between contracts and is aggregated in Dealscan without further information. Additionally, only one threshold for financial covenants is recorded in the database, but thresholds frequently change over the contract period via step-down or step-up provisions. ${ }^{7} \mathrm{Li}$ et al. (2015) show that the latter are included in almost half of all syndicated loan contracts. These cannot be found in Dealscan. We therefore manually collect a novel set of covenants in private credit agreements collecting all covenants from 3,813 contracts. ${ }^{8}$ Importantly, we do not use any text-search program to avoid possible misspecifications in the algorithm.

We record the covenant threshold for each loan for each quarter from origination to final maturity so as to allow for dynamic covenant thresholds in many loans. Furthermore, we find about 80 different descriptions of covenants and classify them, for brevity, into 17 main covenant types. ${ }^{9}$ We also classify covenants into profitability-based covenants and capital-based covenants similar to Christensen and Nikolaev (2012) and comparable to Demerjian (2011). Lenders use capital-based covenants to align incentives ex ante and largely restrict leverage in order to require the firm to keep sufficient net worth and to ensure that firms maintain a specific level of capital within the firm. Profitability-based covenants, on the other hand, are used as a monitoring mechanism to ex-post allocate control rights to the lender (e.g.; Christensen and Nikolaev, 2012; Dyreng et al., 2015; Honigsberg et al., 2015; Hollander and Verriest, 2016). Since they are based on the current performance of the borrower (that is why they are also called performance covenants), lenders can immediately respond to a bad state being reflected in a deteriorating performance of the firm. We further refine the classification scheme of Christensen and Nikolaev (2012) and additionally distinguish capital covenants into leverage, net worth, and short-term covenants. ${ }^{10}$ While the first two reflect the focus of the lender on debt amount and leverage, short-term covenants can be considered more as hybrids of profitability and capital covenant, as they (implicitly) address capital but also account for current changes in a borrower's profit performance. Irrespective of the classification, we

\footnotetext{
${ }^{7}$ Online Appendix I shows an example of a financial covenant section in a loan contract.

${ }^{8}$ Note that the sample is substantially larger compared to prior studies which incorporated SEC filings (e.g.; ElGazzar and Pastena, 1991; Beneish and Press, 1993, 1995; DeFond and Jiambalvo 1994; Sweeney 1994).

${ }^{9}$ The substantially larger number of covenants can be explained by the variety of definitions of the respective variables. Consider for example a debt to capitalization covenant. Debt can be senior, long term or the total value. Capitalization can refer to net worth plus equity or tangible net worth plus equity.

${ }^{10}$ Note that all covenants included in the capital covenants definition are also included in our leverage, net worth, and short-term covenants. The only difference is that we also include Cash and Cash Equivalents in the short-term covenants, which are not included in the classification of Christensen and Nikolaev (2012).
} 
use the definitions of all 80 covenants to identify covenant violations employing the corresponding information from the company's financial statements.

Using the covenants collected from the SEC filings, we construct several proxies as to the strictness of contracts and covenant violations. We define the Number of Financial Covenants simply as the number of financial covenants in each loan contract. A contract with more covenants is more restrictive compared to a contract with fewer covenants. We measure the covenant tightness in a contract by a "Distance to Covenant Violation" or "DCV" measure, analogous to the "Distance to Default" ("DD") in the credit risk literature. It is calculated by subtracting the covenant threshold from the actual value of the financial covenant and normalizing the absolute value of the result with the standard deviation of the financial covenant, which is derived over the previous 12 quarters at the firm level. The covenant with the lowest DCV of all covenants in a contract determines the contract's DCV, comparable to Prilmeier (2016). The DCV value reflects the number of standard deviations an accounting value/ratio may deteriorate before the covenant threshold is violated. A lower value suggests that the contract has stricter covenants. We also calculate the average DCV of all covenants in a loan contract. For this purpose, we use two aggregation levels. First, we calculate the average DCV of all covenants within each of our 17 main covenant types. We then average again across all main covenant types to calculate our measure. The average DCV accordingly reflects the average number of standard deviations covenants may deteriorate before a contract is violated. A contract with a larger average DCV is less restrictive compared with a contract with a smaller average DCV. ${ }^{11,12} \mathrm{We}$ also utilize a Contract Intensity Index that reflects the overall restrictiveness of the loan on the actions of the borrower's management following Bradley and Roberts (2004). The index not only includes financial but also negative covenants. It ranges from zero to

\footnotetext{
${ }^{11}$ Most prior studies only concentrate on specific covenant types when discussing covenant strictness (e.g., Dichev and Skinner, 2002; Chava and Roberts, 2008; Drucker and Puri, 2009; Demiroglu and James, 2010; Nini et al., 2012). Our measure is closest to that proposed in Prilmeier (2016). It is related to Murfin (2012) and Demerjian and Owens (2016) whose measures additionally account for covariances between covenants and incorporate the (multivariate) Normal distribution, in the case of Demerjian and Owens (2016) after simulation of data. Since most firms actively manage accounting data to avoid covenant violations a covenant violation ensures a massive discontinuity in firm type (e.g.; Dichev and Skinner, 2002). This implies that covariances are potentially substantially different between tranquil and stressed periods for a firm. The literature on renegotiation outcomes confirms that firm characteristics substantially change after violations (Chava and Roberts, 2008; Roberts and Sufi, 2009a, b; Nini et al., 2009, 2012) what provides some empirical evidence for this conjecture. Furthermore, the Normal distribution has the shortcoming that it is not able to adequately account for severe jumps in firm characteristics as it is the case when covenants are violated which is addressed to some extent by the simulations in Demerjian and Owens (2016).

${ }^{12}$ Note that using both the DCV (similar to Prilmeier, 2016) and the average DCV accounts for different assumptions regarding correlations between covenants. An example for the calculation of our DCV and average DCV measures is provided in Online Appendix II.
} 
six with high values indicating high contract intensity. It is constructed by adding the indicator variables for dividend restriction, equity sweep, asset sweep, debt sweep, securitization, and a binary variable that is one if the contract includes two or more financial covenants.

A borrower has to comply with most financial covenants on a quarterly basis (Roberts and Sufi, 2009a). A covenant violation constitutes a technical default. We calculate whether the borrower complies with the covenants in each quarter after loan origination until the maturity of the loan, also accounting for step-up and step-down provisions. The terms technical default and covenant violation are used interchangeably throughout this paper. The variable 'Days to Contract Violation' is measured as the difference in time between inception of the contract until the end of the quarter during which a financial covenant is violated for the first time. The variable 'Days Violation to Subsequent Loan' measures the number of days from the violation of a contract until the subsequent new loan is initiated.

To construct our final data set, we merge the contracts from EDGAR with several other data sources. We obtain further loan contract information from Dealscan including loan spread (AISD), maturity, loan amount and lender identity. To identify repeated borrowing from the same lender as well as switching between lenders, we construct the merger history for each lender in Dealscan using information obtained from the FDIC and the National Information Center (NIC). Using Robert's Dealscan-Compustat Linking Database (Chava and Roberts, 2008), we collect quarterly financial statement information from Compustat and merge it to each loan contract. Finally, we obtain borrower default information via the Chapter 11 filings in the UCLA-LoPucki bankruptcy research database. We define a company as being in default if it files for either Chapter 7 or 11 and this is recorded in the LoPucki database. ${ }^{13}$ All variables and the calculation of borrower characteristics and financial covenants using Compustat data items are described in Appendix I. ${ }^{14}$ The final dataset includes 3,813 loans with 5,411 loan facilities from 1,544 borrowers. $^{15}$

\footnotetext{
${ }^{13}$ Only $1.4 \%$ of all defaults are Chapter 7 (Liquidation), therefore, we do not differentiate between Chapter 7 and Chapter 11 filings and include both cases together in our default measure.

${ }^{14}$ In Appendix I Panel B, we only show examples for the calculation of the financial covenants using Compustat data as there are often many refinements of financial variables included in the actual loan contract.

${ }^{15}$ In the following, we perform our analyses at the facility level. However, we repeat all tests also at the loan level. The results are the same.
} 


\subsection{Descriptive Statistics}

Table I provides detailed summary statistics on loan and borrower characteristics. All data are measured in real terms with 2000 as the base year. It shows that the average borrower default rate is $2.5 \%$, the average loan facility is $\$ 298$ million with an All-In-Spread-Drawn (AISD) of 183 basis points (bps) and 2.55 covenants. The distance to covenant violation (DCV) is 2.58 , that is, the strictest covenant can on average change by 2.58 standard deviations before a contract violation occurs. ${ }^{16}$ The contract intensity index is derived following Bradley and Roberts (2004) and loans contain, on average, 4.55 out of 6 possible restrictions. Note that we need to rely on data reported by Dealscan when collecting these restrictions. As we require all 6 indicator variables to be observable, but information on some of the negative covenants is missing in many cases, constructing this index reduces the number of observations in our data set by more than $70 \% .55 \%$ of the loans are violated and these violations occur on average 14 months (427 days) after the loan origination date. Borrowers switch banks in $35.1 \%$ of all cases and violate a financial covenant in more than half $(57.2 \%)$ of all of their prior loan contracts while it takes about 3 years (1,091 days) between a covenant violation and the initiation of the subsequent new loan.

[Table I]

The average borrower size is $\$ 3,291$ million with a profitability of $17 \%$, a current ratio of 1.84 , a leverage ratio of 0.33 , an interest coverage ratio of 15.44 , an average 5 year profit trend which lenders might be projecting forward of -0.01 , and a market-to-book ratio of $1.68 .{ }^{17}$ More than half of the loans are rated and $24.1 \%$ are classified as investment and $34.5 \%$ as non-investment grade. ${ }^{18}$

Panel C of Table I shows the distribution of covenants. More than $60 \%$ of all loan contracts contain a Debt to EBITDA covenant followed by Interest Coverage (44\%) and Fixed Charge Coverage (42\%). Interestingly, while Debt to EBITDA is the most frequently used covenant, Interest Coverage and particularly covenants specifying a maximum level of leverage or a minimum level of net worth (Debt to Capitalization, Debt to Net Worth, Senior Debt to Capitalization) are used for larger loans.

\footnotetext{
${ }^{16}$ Note that a value of 2.58 implies that a contract might be in violation already after three quarters if the strictest covenant's value only changes by 1 standard deviation towards the threshold in each quarter.

${ }^{17}$ As explained in Appendix I, we derive the 5 year profit trend at the firm level via a regression of the ratio of net income to total assets on a constant and a time trend over the previous 5 years where the coefficient for the time trend reflects our 5 year profit trend. Accordingly, a value of about zero indicates that firms have (on average, deflated) constant profits which do not increase or decrease over time. As a robustness check, we also investigate the results including the 10 year profit trend. The findings are unchanged.

${ }^{18}$ Note that our descriptive statistics are very comparable to Nini et al. (2009) when we use the time period 1996 to 2005 as in their study.
} 
In Table II, we segregate the entire sample based on whether or not the borrower violated a covenant in the prior contract.

\section{[Table II]}

Columns (A) and (B) of Table II show mean and median characteristics for borrowers who did not violate a covenant in the prior contract and for those who did. The last column reports the parametric tstatistic (nonparametric z-statistic) of the difference in means (medians) test. Table II shows that the differences between the two groups are substantial. On average, borrowers who have violated a covenant in the prior loan contract have to pay a 98 bps higher spread in the subsequent new loan, accept 0.6 more financial covenants which are in addition significantly more restrictive as measured by their DCV. New loan contracts become stricter after a covenant violation in the prior loan, also reflected in the Contract Intensity Index. The occurrence of profitability-based covenants in subsequent loans increases after violations in the prior loan, while the occurrence of capital-based covenants is slightly lower. Table II also shows that the percentage of secured loans almost doubles. Borrowers who violate covenants are also smaller, higher levered with lower interest coverage and market-to-book ratios and are lower rated.

\section{Covenant Violations and Loan Contract Design}

In this section we investigate how lenders allocate control rights in new loans after a covenant violation in the previous loan. That is, we examine how loan contract terms change in new loans after covenant violations in the prior loan. We hypothesize that a covenant violation is a signal which induces lenders to act as tough principals in any subsequent new loan by implementing a tougher structure reflected in both price and covenant loan terms. We then provide several tests that help to rule out alternative hypotheses that might explain our findings such as unobservable borrower characteristics, higher ex-ante credit risk of borrowers who have violated covenants in earlier loans, managerial agency problems, potential hold up of borrowers by lenders, or differences in corporate governance.

\subsection{Loan Contracting following Covenant Violations in the Prior Loan}

In this subsection, we analyze how price and covenant loan terms change in new loans after covenant violations in the prior loan. If covenant violations provide a negative signal that induces lenders 
to act as "tough principals" in the subsequent new loan because of borrower stigma, this will be reflected in tougher loan contract terms. More precisely, we expect to find higher loan spreads and more and tighter covenants in new loans. Our basic regression specification has the following form:

$$
\begin{aligned}
\text { LCT }= & a+b * \text { Prior Covenant Violation }+c * \text { Loan Characteristics } \\
& +d^{*} \text { Borrower Characteristics }+e * \text { Other Controls }+\varepsilon
\end{aligned}
$$

LCT ('Loan Contract Terms') refers to two different groups of dependent variables. The first group contains a common proxy to measure the cost of loans (AISD), the second group describes the new loan's covenant package as measured by i) the Number of Covenants, ii) the Average Distance to Covenant Violation, iii) the Distance to Covenant Violation and iv) Contract Intensity. The results are reported in Table III.

\section{[Table III]}

Table III reports five models with different dependent variables. It also shows the regression methodology used in each regression. In addition to the reported variables, all regressions further include year and industry fixed effects, indicator variables for the different ratings of borrowers at contract initiation, and loan type and loan purpose fixed effects. All variables are defined in Appendix I. Standard errors are robust to heteroscedasticity and clustered at the borrower level.

Column 1 of Table III reports the results of an OLS regression relating AISD to prior covenant violation and our control variables. We find that covenant violations in the prior contract increase loan spreads in the subsequent loan by an average of $18 \mathrm{bps}$, significant at the $1 \%$ level and economically meaningful. It translates into $\$ 0.54$ million higher annual loan costs for a borrower who violated a covenant in the prior contract. Most of the other control variables are also highly significant and carry the expected signs. For example, larger loans and loans containing performance pricing grids have lower spreads, secured loans and loans of highly leveraged borrowers carry larger spreads.

We next explore the implications of prior covenant violations on the covenant package of the subsequent new loan. If prior covenant violations are a stigma for borrowers we expect to find that the covenant package overall becomes more restrictive in the subsequent new loan (e.g.; Dewatripont and Tirole, 1994) despite our high number of control variables. Columns 2 to 5 of Table III report the results. First, we relate the number of financial covenants in the new contract to prior covenant violation and our 
control variables using ordered logit regressions. ${ }^{19}$ We find that a prior violation increases the number of financial covenants used by lenders in the subsequent new loan. The coefficient is significant at the $1 \%$ level. The coefficient for loan maturity is positive and significant which is consistent with Rajan and Winton (1995) who argue that long term loans have more covenants. In other words, monitoring via short term debt or via covenants on longer term loans are substitutes. The OLS regression results for the (average) DCV are shown in Column 4 (3). A covenant violation in the prior contract leads to stricter covenants, with thresholds in the subsequent contract set (on average) 1.06 (1.5) standard deviations closer to the actual accounting value at the time the new loan is made. Column 5 in Table III reports the impact of a covenant violation in the prior loan on contract intensity in the subsequent loan using an ordered logit regression. It shows that contract intensity is increasing, the coefficient, however, is only weakly significant. Note that the number of observations drops by almost $70 \%$ in Column 5 because we need to rely on data recorded in Dealscan in order to calculate the index in a similar way as in Bradley and Roberts (2004), Demiroglu and James (2010) and Bharath et al. (2011). Information on some of the negative covenants is missing in many cases.

In Panel B we report the results for a first alternative explanation for our findings already in this section for brevity. We include borrower fixed effects to control for unobservable borrower characteristics as suggested in e.g. Nikolaev and van Lent (2005). ${ }^{20}$ The results remain virtually unchanged. The results for the covenant terms in the subsequent new loan after a violation in the prior loan confirm our earlier findings that lenders act as tough principals after having received a negative signal from the prior project the number and tightness of covenants significantly increases after a covenant violation in the prior loan contract.

\subsection{Alternative Explanations}

\subsubsection{Alternative Explanations - Borrower Credit Risk after Covenant Violation}

An alternative explanation for our results could simply be higher ex-ante credit risk of borrowers who have violated covenants in their prior loan. At the time of a covenant violation at least some of the

\footnotetext{
${ }^{19}$ We use ordered logit regressions because the number of covenants is an ordinal measure in our context. In robustness tests, we also use OLS models as well as Poisson models and get similar results. We do not report these tests for brevity.

${ }^{20}$ The table with all coefficient estimates is provided in the Online Appendix.
} 
borrower's financials are stressed. However, the literature on renegotiation outcomes reveals that the shift in control rights to lenders due to a covenant violation has important implications on borrower risk. In the immediate period after a covenant violation borrowers reduce acquisitions and investments, do not assume further leverage and decrease shareholder payouts, while risk shifting is limited and corporate governance improved (Chava and Roberts, 2008; Roberts and Sufi, 2009a, b; Nini et al., 2009, 2012). Table I shows that subsequent new loans are originated, on average, 3 years (1,091 days) after a covenant violation.

In this subsection, we therefore want to test if covenant violations explain differences in borrower credit risk between violating and non-violating firms in the subsequent years, prior to the initiation of the new loan contract. We investigate borrower risk from two angles.

First, we investigate borrower PD directly. We hypothesize that borrower PD is high at the time of a covenant violation and conditional on not declaring bankruptcy later on, decreases again over the subsequent periods. We augment our loan data with Chapter 11 filings obtained from the UCLA-LoPucki bankruptcy research database which ultimately collects its information from court files or SEC filings. Most importantly, we derive the exact default date of each borrower from LoPucki. We also need a starting point from which we estimate a borrower's PD. If a covenant is violated we take the violation date, if no covenant violation occurs we choose the contract end date as the date for repaying the loan without violating a covenant. Figure 1 plots the default probability ${ }^{21}$ for borrowers after no covenant violation (Figure 1.A) and after a covenant was violated (Figure 1.B).

[Figure 1]

Figure 1.A plots the development of a borrower`s PD over time after no covenant has been violated. Directly after the full repayment of the loan borrowers have a PD of almost zero. In line with Flannery (1994), the PD increases (for levered firms) the longer the time period. Figure 1.B plots the development of a borrower`s PD over time after a covenant violation occurred. Borrowers have, on average, a PD of $30.26 \%$ at the first day after the violation (not plotted for scaling purposes). Panel B shows that a borrower`s PD is substantially higher in the period immediately following the violation and decreases as a convex function over time. Borrowers exhibit a substantially higher likelihood to default

\footnotetext{
${ }^{21}$ In our analyses, we refer to the model-implied PD of a logistic regression model of an indicator variable for default on a dummy for the violation in a past contract, the logarithm of the days since the past contract with no violation or the days since the last violation depending on what occurred lastly, the interaction between these two terms and loan and borrower control variables. We use a logistic model due to its closed form solution which allows for a simple graphical analysis of PD over time.
} 
especially in the first 100 days after a violation. Figure 1 implies that the PD decays to a level comparable with the PD of non-violating borrowers approximately after two years (882 days).

Second, we test if covenant violations predict increases in credit risk. If this is not the case over a longer period, this provides evidence that borrower credit risk between firms, which violate a covenant and those that do not, is not significantly different at the initiation of a new loan. ${ }^{22}$ We investigate this in more detail in Table IV using various measures of credit risk: borrower default (Panel A), rating downgrade (Panel B), change in net worth (Panel C), change in leverage (Panel D), and the number of subsequent loss making quarters (Panel E). ${ }^{23}$

\section{[Table IV]}

Regarding borrower default, we define an indicator variable which is one in the year of the default of a borrower and zero otherwise and regress it on past covenant violations and (lagged) control variables. The latter are end of year borrower characteristics and year, industry and rating fixed effects. We investigate the impact of a covenant violation on a firm's default probability in each of the years $t+1$ to $t+5$ after (no) violation using logit regression models. Additionally, we employ a Cox proportional hazards model to address censoring of newer loans to firms in our data set which have less time to go bankrupt. A positive coefficient in this model is indicative of an increase in default probability. Panel A of Table IV shows the results. It reveals that the default probability of borrowers who violate a covenant and those who do not is comparable over the five years following a covenant violation. That is, our variable, covenant violation, does not load in any of the credit risk regressions. ${ }^{24}$ Note that this predictive analysis of course excludes borrowers which default at the same time when a covenant is violated.

We then investigate rating downgrades using our S\&P ratings. We define an indicator variable which is one in the year of a rating downgrade of a borrower and zero otherwise. We follow the same methodology as in Panel A, however, we additionally investigate all results by also including borrower fixed effects to rule out that unobservable borrower characteristics are influencing our findings. Panel B of Table IV shows the results. Excluding borrower fixed effects in columns 2 to 6 , we observe that

\footnotetext{
${ }^{22}$ Note that Li et al. (2015) show that at initiation of a contract borrowers with higher risk often receive a grace period with covenants being less restrictive in the first year but becoming tighter over the life of the loan. This suggests that if covenant violations in the prior loan would correspond to higher borrower risk at the initiation of the subsequent new loan we should actually observe a less tight financial structure in the new loan after prior covenant violations.

${ }^{23}$ A detailed version of Table IV including all control variables is provided in the Online Appendix.

${ }^{24}$ Note that we cannot include borrower fixed effects in these regressions due to missing variation of the dependent variable for non-defaulting firms.
} 
downgrades seem to be more likely in years $t+2$ and $t+3$ after a covenant violation. However, when we control for unobservable borrower characteristics these effects disappear and the probability of being downgraded is comparable for borrowers who violate a covenant and those who do not in the following 5 years. The Cox proportional hazards model in column 1 confirms these findings.

In Panels $\mathrm{C}$ and $\mathrm{D}$ we investigate the change in borrower net worth (scaled by total assets) and leverage, respectively, from year $t$ to year $\mathrm{t}+\mathrm{i}$, with $\mathrm{i}$ ranging from 1 to 5 years. That is, we calculate for each borrower the difference of net worth and leverage between its value in $t+i$ and its value in $t$ and regress it on our covenant violation indicator variable and control variables using OLS regression models. In both Panels, columns 1 to 5 show the results excluding and in columns 6 to 10 including borrower fixed effects. We observe that in the first 2 years after a covenant violation borrower net worth reduces compared with its value in period t while leverage does not change significantly except with $10 \%$ significance in Panel D model 8. It is important to note that new loans are originated, on average, 3 years (1,091 days) subsequent to a covenant violation. Accordingly, we conclude that on average borrower credit risk between those firms that violate a covenant and those that do not is comparable at the initiation of a new loan contract also with respect to borrower leverage and net worth.

Our next test investigates the number of loss making quarters of a firm. In each quarter we count the number of subsequent quarters where the quarterly net income of the borrower is negative. In our regressions we stick to annual control variables for consistency. ${ }^{25}$ For borrowers with a covenant violation we use control variables in the year prior to the violation year and the number of loss making quarters after the violation, for borrowers with no covenant violation we use control variables at the end of a year and the number of loss making quarters from Q1 of the following year. Panel E shows that irrespective of whether we include borrower fixed effects (column 7) or not (column 2), a covenant violation does not predict the number of subsequent loss making quarters. Also this test allows us to conclude that borrower risk in future periods is not significantly different between firms that violated a covenant in the past loan and those that did not. This is in line with the findings in prior literature and our results in Figure 1 that borrower risk swiftly reduces again back to "regular" levels after a shift in control rights.

\footnotetext{
${ }^{25}$ In all our regression specifications we stick to the standard in the literature and use annual (end of year) control variables to avoid noise in our control variables. However, as mentioned before, we identify and track covenant thresholds and violations in each quarter.
} 
Finally, we investigate refinancing opportunities of borrowers. Refinancing possibilities could be related to borrower risk and this might be reflected in our results. A potential concern could be that some borrowers refinance their existing loans before a violation actually occurs. These borrowers could strategically negotiate different terms for the new, refinanced, loan and therefore avoid violating the covenants of the existing loan. To address this potential concern, we exclude all overlapping loans. That is, we identify any new loan to borrowers, while their existing loans are yet to mature, and drop them from our sample. We repeat our regressions, also including borrower fixed effects, and report the results in Panel F of Table IV. All control variables from Table III are included but not shown for brevity. The results are very similar to those reported earlier. Borrowers with prior violations pay higher spreads, and face more covenants which are on average more restrictive.

\subsubsection{Alternative Explanations - Borrower Credit Risk at Loan Initiation}

In this sub-section, we provide further tests that seek to rule out that our results are driven by borrower credit risk at the initiation of the new loan. First, we use propensity score matching models following the approach outlined in Rosenbaum and Rubin (1983) and applied in for example Drucker and Puri (2005), Bharath et al. (2011) and Saunders and Steffen (2011). We match borrowers who have violated a covenant to borrowers who did not violate a covenant based on their characteristics at the time of (no) violation. These characteristics include size, profitability, current ratio, leverage, coverage, 5 year profit trend, market-to-book ratio, industry and rating and the number of previous loans. Furthermore, we require the loan characteristics (maturity, size, secured, performance pricing), the loan type and the loan purpose as well as the year of (no) covenant violation to be comparable. We also add the change in all borrower characteristics as well as in borrower credit rating from the time of (no) covenant violation until the initiation of the subsequent loan contract to the matching model. This ensures that borrower characteristics and credit rating between violators and non-violators are comparable at the time of (no) violation as well as the change in their characteristics and credit quality is similar until the initiation of the new contract. We use different estimation methods: Nearest Neighbor Matching and Local Linear Regressions (LLR) using both the Gaussian and the Epanechnikov kernel. In contrast to Nearest Neighbor Matching, LLR uses all information from the matched sample weighting the observations based on the 
differences in the propensity score between borrowers who violated and those who did not. Table V shows the results.

Panel A of Table V reports the results which are very similar to our other tests. Borrowers who have violated covenants in the prior loan pay higher spreads and face more and stricter covenants in the subsequent loan also when they are matched by their characteristics and their credit quality as well as the change of these until the initiation of the new contract.

[Table V]

Second, we use a regression discontinuity design similar to the approach in Chava and Roberts (2008). We cannot exactly replicate their design because they are able to use quarterly consecutive data in their analysis while we have unbalanced panel data. The basic idea behind a regression discontinuity design is to compare effects between comparable borrowers which only differ in the discontinuity of a covenant violation. Chava and Roberts (2008) investigate the effects of a covenant violation, controlling for borrower characteristics at the time of violation, on capital investment of the firm in the subsequent quarter. If we directly transferred this idea to our setting, we would investigate the effects of a covenant violation, controlling for borrower characteristics at the time of (no) violation, on the contract terms of the subsequent loan which might be initiated several years after the covenant violation. However, borrower characteristics might change substantially over such a long period and we would not compare effects between similar borrowers. We therefore examine the sample of borrowers who have an ongoing loan contract in the year prior to the initiation of the new loan and use the covenant (violation) information of these loans for our analysis.

Intuitively, we investigate price and covenant terms of two similar borrowers who are close to a covenant threshold where one is slightly above and the other slightly below the threshold. That is, if the price and covenant terms are different it is likely only due to the covenant violation. For each new contract, we examine the distance of each covenant in a borrower's prior loan to its respective covenant threshold at the end of the year prior to the initiation of the new loan. In this analysis, we only include borrowers where at least one covenant in the old contract is close to its threshold. For this purpose, we use our DCV measure with a cutoff point of one. That is, we only include contracts with a DCV below 1 at the end of the year prior to the initiation of the new loan (the results for a 0.5 standard deviation as cut-off naturally include fewer observations but are very similar). We then re-estimate the tests from Table III. 
The results are reported in Panel B of Table V. All control variables from Table III are included but not shown for brevity. The results are similar to our previous results. Borrowers pay higher spreads and face tighter covenants after having violated covenants in the prior loan consistent with our hypothesis that a covenant violation is a stigma for borrowers which induces lenders to act as tough principals.

\subsubsection{Alternative Explanations - Disciplining Effect on Management}

An alternative explanation for our results could be that covenant violations are a consequence of self-interested behavior of managers and lenders seek to discipline management after covenant violations. If this is the case we do not expect contract terms to become stricter when shareholders oust their CEO between a covenant violation and the initiation of the new contract. Kaplan and Strömberg (2001, 2003) show that investors intensely screen firms prior to contract initiation especially with respect to management, a standard notion also in the bank lending literature (e.g.; Broeker, 1990; Diamond, 1984, 1991). If management is blamed after covenant violations, we do not expect contract terms to become stricter when the CEO changes prior to the initiation of a new loan contract. In short, we test for the effect of managerial agency problems.

To test this empirically, we enhance our data set with data from ExecuComp and construct a dummy variable, which is one if the CEO changes between the initiation of the prior and the subsequent new contract and zero otherwise. Note that in this analysis we exclude all firms with no information on the CEO in Execucomp. Furthermore, we interact the indicator variable for a change in CEO with prior covenant violation. If management is blamed by lenders after covenant violations we expect the coefficient of the interaction term to be of the reverse sign to that of prior covenant violation and significant. We also follow Eisfeldt and Kuhnen (2013) who identify three reasons for the change in CEO: i.) the CEO was forced to resign, ii.) the CEO retired, and iii.) the reason for the change is unknown. Eisfeldt and Kuhnen provide data from 1992 to 2006, which we update with the reason for the change in CEO provided by ExecuComp for the 2007 to 2010 period. We also build three indicator variables for the reason of the change in $\mathrm{CEO}$ and interact these with the prior covenant violation indicator variable.

Panel A in Table VI provides descriptive statistics. It shows the number and percentage of CEO changes for firms included in our data set using data from only ExecuComp from 1996 to 2010 (column 1), only Eisfeldt and Kuhnen data from 1996 to 2006 (column 2), and a combination of both, that is, 
Eisfeldt and Kuhnen from 1996 to 2006 with ExecuComp data from 2007 to 2010. Panel A shows that the differences among these data sets are small. About $18 \%$ of CEOs resigned, while $30 \%$ retired and for $52 \%$ the reason for the change in CEO is unknown. Overall, we include 523 changes in CEO (387 when we only use Eisfeldt and Kuhnen's data).

\section{[Table VI]}

The multivariate results, including the change in CEO, are shown in Panel B of Table VI. ${ }^{26}$ Note that due to insufficient observations we cannot estimate the regression for contract intensity. None of the managerial variables interacted with prior covenant violation indicate a disciplining effect on management of a prior covenant violation, that is, the interaction terms of our indicator variables for a change in CEO and prior covenant violation are insignificant. This argues for a stigma of the borrowing firm at the initiation of a new loan when a covenant was violated in the previous loan which is not related to managerial agency problems.

\subsubsection{Alternative Explanations - Hold Up}

A further alternative explanation for tougher covenant structures after prior loan violations is a hold up of borrowers by banks. Sharpe (1990) and Rajan (1992) argue that information asymmetries allow the existing lender to extract rents from the borrower due to the informational advantage acquired over the lending relationship. The empirical literature provides mixed results with respect to borrowing costs and hold up by banks. While Berger and Udell (1995) find that loan rates decrease over time due to relationship effects, Petersen and Rajan (1994), among others, do not detect a change in rates. In contrast, Degryse and Van Cayseele (2000), and Degryse and Ongena (2005) observe increasing loan rates over the duration of a relationship. We hypothesize that firms with capital market access have access to more funding sources, which allows them to more easily avoid a tougher financial structure after a prior covenant violation.

To test this empirically, we define an indicator variable for debt capital market access which is one if the borrower issues a bond or note of at least USD 10 million between the old and the new bank

\footnotetext{
${ }^{26}$ We show the results using the data of Eisfeldt and Kuhnen from 1996 to 2006 with ExecuComp data from 2007 to 2010, related to column 3 in Panel A of Table VI. Further variations of variables and data source are provided in the Online Appendix.
} 
loan. ${ }^{27}$ Note that for this test we are able to include only loans granted in the time period 2001 to 2010 as we rely on data from CapitalIQ where information on public debt is available only since 2001. We match these data to our data set and interact the debt capital market access indicator variable with prior covenant violation. If alternative funding sources such as bonds or notes protect borrowers from being held up by banks after covenant violations we would expect the interaction term between prior covenant violations and public debt market access to be of the reverse sign to that of prior violation, and significant. Panel A of Table VII presents the results. We observe that access to public debt markets does not change our previous findings. Lenders act as tough principals after a covenant violation irrespective of capital market access of borrowers to public debt markets. Interestingly, the number of covenants seems to increase after a violation when firms issue bonds and notes in addition to bank debt. Overall, our results argue against a hold up of borrowers after covenant violations.

\section{[Table VII]}

\subsubsection{Alternative Explanations - Corporate Governance}

We next investigate the role of differences in firm governance, that is, institutional (equity) ownership, which might influence our results. Institutional investors are in general held to be more "prudent" what can be explained by statutory and legal restrictions (O'Brien and Bhushan, 1990). Accordingly, the degree of institutional ownership might proxy for (externally) monitoring the potential threat of extracting private benefits as suggested by Amiram and Owens (2012). Banks might therefore implement a less tough financial structure when more shares are held by institutional investors. However, institutional shareholders also hold a convex cash flow claim and could try to increase firm risk after a loan is originated (Dewatripont and Tirole, 1994; Shleifer and Vishny, 1997).

We investigate the impact of institutional ownership via the percentage of institutional shareholders at the initiation of a new loan contract using data from $13 \mathrm{f}$ filings which we match to our data set. ${ }^{28} \mathrm{We}$ also interact this variable with our indicator for prior covenant violations. Panel B of Table VII

\footnotetext{
${ }^{27}$ We are aware of a potential selection problem, that is, only good borrowers might self-select to access debt capital markets. However, given that a borrower indeed successfully issues a bond or note although a covenant is violated this appears to be the most unbiased signal of actual access to debt capital markets, and sufficient at least for the purpose of our (robustness) test.

${ }_{28}$ In addition to the percentage of institutional shareholders we also investigate the change in institutional shareholdings from the covenant violation (initiation of the prior loan) to the initiation of the new loan contract for
} 
shows that non-price loan contract terms are unaffected by institutional shareholdings. Lenders increase the number and strictness of financial covenants in a new loan contract after borrowers have violated a covenant in a prior loan irrespective of the level of institutional ownership. Interestingly, the loan spread is affected by institutional shareholdings as both prior covenant violation and its interaction term with institutional ownership are statistically significant at the $1 \%$ level.

\section{Severity and Type of Covenant Violation and Loan Contract Design}

\subsection{Covenant Violation Severity}

We are also interested if the severity of a covenant violation has an impact on the loan contract terms of the subsequent new loan. We measure violation severity by the number of the financial covenants that are violated at least once in the prior loan. We hypothesize that the toughness of the financial structure in a new loan contract will increase the greater the violation severity in the prior loan. In other words, we test if there exist differences in stigma which result in different levels of toughness. We investigate this hypothesis with multivariate regression models using the same methodology as in Table III. Table VIII shows the results.

[Table VIII]

We split our prior covenant violation variable using indicator variables for the number of covenants, which are violated in the prior loan contract. The results indicate that as the number of covenant violations increases, lenders implement more and stricter covenants at the initiation of the subsequent new loan. Borrowers also have to pay a higher loan spread the more covenants are violated in the prior contract.

Overall, we conclude that the financial structure of a loan contract becomes tougher the greater the severity of covenant violation in the prior loan. Given that firms often try to manage accounting information so as not to violate covenants (Dichev and Skinner, 2002) and lenders evaluate borrower characteristics and prospects thoroughly before deciding not to renegotiate and allow for a violation (Denis and Wang, 2014), a higher severity reflects a stronger negative signal to future lenders, which

violators (non-violators). Furthermore, we examine the impact of institutional ownership concentration via the Herfindahl-Hirschman Index, related to Liao (2015) but being aware of the potential selection problems of ownership structure as pointed out in Nikolaev (2015b). In addition, we perform all regressions also including borrower fixed effects. The (unreported) results confirm the findings in this subsection in all cases. 
induces them to act as increasingly tough principals when allocating control rights in the subsequent new loan.

\subsection{Covenant Violation Type}

In analyzing the dynamic allocation of control rights over consecutive private debt contracts of the same borrower we are also interested if violations of specific covenants have a different impact on the design of contract terms in the subsequent contract. We follow a two-step procedure and first investigate if violations of different types of covenants have differing effects. Thereafter, we investigate which type of covenant is included conditional on the type of covenant violated. For this purpose, we refine the classification scheme of Christensen and Nikolaev (2012) and split covenants into profitability-based covenants and capital-based covenants where we additionally distinguish the latter between leverage, net worth and short-term covenants. Besides this refinement, we also add the Cash and Cash Equivalents covenant to the short-term covenants which is not included in the general definition of capital covenants. Lenders use capital-based covenants largely to restrict leverage and require the firm to keep sufficient net worth while profitability-based covenants are used especially when accounting signals exhibit a higher correlation with the underlying state of the borrower, such that lenders can immediately respond to a deteriorating performance of the firm. Short term covenants can be considered as a hybrid between capital- and profitability-based covenants as they relate to both covenant types.

To investigate the impact of the violation of a specific type of covenant on loan contract terms we split our variable, prior covenant violation, into violations of profitability-based covenants and violations of capital-based covenants. The results are shown in Table IX.

\section{[Table IX]}

Table IX shows that violations of profitability-based covenants induces the lender to act as tough principal in the subsequent new loan by implementing more and tighter covenants and demanding a higher loan spread. The same holds for capital-covenants. We conclude from our findings that a covenant violation results in a stigmatization of the borrower irrespective of the type of covenant violated.

As a next step, we investigate which types of covenants are implemented in a new loan after specific types of covenants are violated in the prior loan. Panel B of Table IX provides some descriptive 
statistics. ${ }^{29}$ It shows the percentage of loan contracts in our data set including a specific covenant for specific types of covenant violation in the prior loan. It reveals that new loan contracts very often again include those covenants which have been violated in the prior contract. For example, after the violation of a profitability-based (capital-based) covenant, $96.46 \%(68.28 \%)$ of subsequent new loans include a profitability-based (capital-based) covenant. This also holds when we further distinguish capital-based covenants into leverage, net worth and short-term covenants. In all cases, more than $50 \%$ of new loans also incorporate these covenant types when they have been violated in the prior loan.

We then define several indicator variables which are one if a specific covenant type is included in a loan and zero otherwise. We regress these on prior covenant violations distinguishing by the type of covenant which was violated in the prior loan to identify the effect of a specific type of covenant violation on the probability to include a specific type of covenant in the subsequent new loan contract. ${ }^{30}$ Furthermore, we investigate the percentage of profitability-based covenants in the new loan after violations of specific types of covenants in the prior loan. Note that our data only include 54 (or 2\%) 'covenant lite' loans, that is, loans with no covenants. The percentage of capital-based covenants is therefore very close to 1 minus this variable. Accordingly, the results for the percentage of profitabilitybased covenants are virtually identical (in reverse) to the results for the percentage of capital-based covenants. Consequently, for brevity, we only show our findings for the percentage of profitability-based covenants.

Panel C in Table IX confirms our univariate results from Panel B, that is, lenders increase those covenants which have been violated in the prior contract. ${ }^{31}$ After the violation of a profitability-based covenant the probability that a profitability-based covenant will be included in the subsequent new loan increases while the probability of including a capital-based covenant decreases. Also, the percentage of profitability-based covenants relative to capital-based covenants increases in the new loan. Accordingly, the violation of a performance covenant results in a tendency for lenders to rely increasingly on profitability based covenants. Model 5 illustrates that the overall increase of profitability-based covenants

\footnotetext{
${ }^{29}$ Online Appendix III reports an additional univariate analysis of profitability-based versus capital-based covenants for loans of borrowers that have and have not violated covenants in the prior loan.

${ }^{30}$ Note that the results for the number and the probability for including a covenant in a loan contract are virtually the same. For brevity, we therefore only show the results for the probability to include a covenant type.

${ }^{31}$ Note that this relates to previous literature which shows that lenders often include covenants with the highest accuracy for the respective firm (e.g.; Ball, Bushman, and Vasvari, 2008; Costello and Wittenberg-Moerman, 2011; Demerjian, 2011).
} 
in the covenant mix of the subsequent new loan is about $10 \%$. A comparable pattern can be observed for capital-based covenants. A violation of a capital covenant in the prior loan results in a higher probability to increase a capital-based covenant again in the subsequent loan. This also holds when we further differentiate between leverage, net worth and short-term covenants in model 3. However, the violation of a capital-based covenant in the prior loan does not change the probability of including profitability-based covenants. However, Models 4 and 5 confirm that overall increase of capital-based covenants in the covenant mix of the subsequent new loan is the same as for profitability based covenants with about $10 \% .^{32}$

In sum, this sub-section shows that the type of covenant violation is irrelevant to lenders regarding the stigma for the borrower. In all cases, lenders implement a tougher financial structure by charging a higher spread and including more and tighter covenants of the type which is also violated in the prior loan contract.

\section{The Dynamic Effect of Past Covenant Violations on Future Loan Contract Terms}

In this section, we investigate how price and covenant terms change when firms repeatedly borrow in private loan markets. We first graphically explore the dynamics of average loan spreads, number of covenants in loan contracts, the average distance to covenant violation ${ }^{33}$, and contract strictness as a function of repeated borrowing in the loan market. Figure 2 shows how the four measures develop over time for borrowers who repeatedly obtain new loans. The number of observations is provided in parentheses.

[Figure 2]

A first time borrower pays on average 178 bps above LIBOR which decreases to 108 bps in its fourth loan contract, conditional on never having violated a covenant. Borrowers become less opaque if they frequently borrow in the loan market. At the same time, violating a covenant in the first three loans

\footnotetext{
${ }^{32}$ In unreported results, we also test the equality of the coefficients between profitability-based covenants and capital-based covenants in model 4 and in model 5 between profitability-based covenants and leverage, net-worth and short-term covenants. All tests cannot reject that the coefficients are the same. In the Online Appendix, we also report further results regarding leverage, net-worth and short-term covenants which provide further confirmation that lenders implement those covenant types which have been violated in the prior contract.

${ }^{33}$ The results for the distance to covenant violation are qualitatively very comparable.
} 
increases loan spreads to 238 bps in the fourth loan. A violation in the first loan increases loan spreads to 228 bps, not violating a covenant in the second loan reduces spreads to 148 bps then in the third loan. Overall, Figure 2 shows that covenant violations result in higher spreads for covenant violating borrowers in subsequent loans.

A similar pattern is observable with respect to the number of financial covenants in new loan contracts. Panel B shows how the average number of the financial covenants develops over time as borrowers return to the loan market for subsequent loans. Not violating covenants reduces the number of covenants in subsequent loans, whereas the number of covenants increases following a covenant violation in the prior loan contract.

Panel C and D show the results for average DCV and contract intensity. The figures depict comparable patterns again. Covenant violations result in stricter average covenant thresholds and contract terms in subsequent loans. Not violating a financial covenant causes average thresholds and contracts to be less strict.

We also explore price and contract terms dynamically over the second and third loan as a function of whether or not the borrower violated a covenant in the prior loan in a multivariate setting. ${ }^{34}$ Second Loan is an indicator variable equal to one if the borrower has obtained a second loan in our sample period (the first loan is the base case). "Second Loan, Violation in First Loan" is an indicator that is one if the borrower violated a covenant in the first loan. "Third Loan, Violation in Second Loan" is an indicator variable that is one if the borrower violated a covenant in the second loan. The first loan is the base case. ${ }^{35}$ The fourth (or even later) loans of borrowers are excluded from this analysis due to time-series data limitations. We report the results in Table X.

\section{[Table X]}

Table $\mathrm{X}$ shows that borrowing without covenant violation has no significant effect on interest rates in the subsequent loan; however, borrowers face less strict covenants (i.e. a higher distance to covenant violation). These benefits accumulate over the second and third loan. Consistent with our earlier findings, after a covenant violation in either the first or the second loan, lenders increase interest rates in

\footnotetext{
${ }^{34}$ Note that Prilmeier (2016) provides a complementary analysis by investigating the effects of relationship duration on non-price loan contract terms.

${ }^{35}$ Note that including the first loan as the base case increases the number of observations because we do not require a measure of prior covenant violation to be available for these. Given that potentially some of these loans are issued after prior covenant violations the multivariate results in this section are rather conservative.
} 
the second and third loan. Moreover, they also increase the number of covenants and make them stricter. Note that the inclusion of borrower fixed effects (models 6 to 10) does not change our findings. In the Online Appendix, we present further results related to the severity of covenants violations and repeated borrowing which confirm our previous results also in this setup. Overall, we observe that lenders act as tough principals due to the stigma for borrowers with a covenant violation in the prior loan. This stigma increases and loan contracts become stricter the more often borrowers violate their loan covenants. However, repeated borrowing without violating a covenant reduces the stigma again over time. Accordingly, the "always" in our introductory quote can be relativized to some extent.

\section{Covenant Violations and the Supply Side of Capital}

In this subsection, we investigate the effect of covenant violations on the size and composition of the lending syndicate in the new loan subsequent to a covenant violation in a prior loan. If the covenant structure implemented by lenders successfully addresses problems such as a stigma due to a prior covenant violation, we expect to find syndicates of similar size in loans to both violating and non-violating borrowers as well as syndicate members willing to make loans of a similar size. We test this using the number of syndicate participants as the dependent variable.

[Table XI]

The results are reported in column (1) of Table XI. We find no significant differences in the number of lenders that participate in syndicates of loans to borrowers who violated a covenant in the prior loan or those who did not. The coefficient of our covenant violation indicator variable is even positive consistent with covenants efficiently allocating control rights and not decreasing lender participation in the primary loan market. Intuitively, larger loans are positively related to the number of lenders. To ensure that our results are not driven by loan size, we scale the number of lenders by the dollar facility amount and run the same specification. We report the results in column (2) and show that the number of lenders relative to the loan amount is also unaffected as contract terms are adjusted. ${ }^{36}$

Finally, we investigate if the probability to switch to a new lender is different between borrowers who have violated covenants and those that did not. Note that in addition to successfully addressing

\footnotetext{
${ }^{36}$ In robustness checks we also include borrower fixed effects. The results are comparable.
} 
problems such as stigma this also tests if lenders extract "unfair" rents after a violation in the prior contract. If this was the case, we expect to find a higher probability of switching to a new lender. We define Switch as an indicator variable equal to 1 when the borrower did not have a lending relationship with the lead arranger in a new contract for at least 1 year and zero otherwise (e.g.; Ioannidou and Ongena, 2010). ${ }^{37}$ Column (3) of Table XI reports the results. Borrowers who have violated covenants in the prior loan are neither less nor more likely to switch to new lenders than those who did not violate covenants.

Overall, these results suggest that covenant structure adjustments help to overcome supply side frictions in primary loan markets because control rights are allocated efficiently.

\section{Conclusion}

Covenants are an important element of loan contracts and can be found in almost every private credit agreement. In this paper, we analyze the effect of covenant violations on the design of the subsequent new loan contract to the same borrower. In particular, we focus on loan contracting as mechanism to allocate control rights efficiently. In line with Dewatripont and Tirole (1994), we contend that lenders have to act as "tough principals" when borrowers have violated covenants in the prior contract due to a stigma attached to it. Overall, we provide empirical evidence consistent with this prediction.

At the heart of our paper is a novel and hand-collected data set of covenants found in 5,411 loan facilities over the 1996 to 2010 period. Our results show that lenders increase loan spreads and implement more and tighter covenants in newly issued loans after a violation in the prior contract consistent with a "tougher financial structure" after a negative signal in the prior loan. We provide arrays of robustness tests to rule out several alternative hypotheses, such as differences in credit quality between violators and nonviolators, unobservable borrower characteristics, refinancing opportunities, hold up, borrower governance or disciplining of management after violations. We also observe that lenders implement a tougher financial structure in the subsequent new contract irrespective of the types of violated covenant but increasing in toughness when the severity of covenant violation was more severe in the prior loan. Our results extend over multiple loan contracts. Finally, we document that the number of lenders in syndicates of loans to borrowers that have violated covenants before is insignificantly different from those loans of

\footnotetext{
${ }^{37}$ We use other definitions for Switch in robustness tests and find similar results.
} 
non-violating borrowers. Moreover, we do not find differences in the switching of borrowers with or without prior violations suggesting that covenants help mitigate supply side frictions in primary loan markets.

There are several avenues for future research. First, it would be interesting to compare new bond issuances of borrowers that have violated covenants with bond issuances of non-violating borrowers. Bondholders, due to their more dispersed ownership are less able to monitor and often free-ride. Second, the implications of our findings on the secondary market for loans might be very interesting. For example, how do secondary market prices of loans react when borrowers are found to have violated covenants in a loan that is being traded? Third, an issue also raised by Christensen et al. (2015) is potential cross-country differences in the allocation of control rights dependent on the jurisdiction. Finally, the relationship between financial covenants, performance pricing and loan price deserves further attention. Hopefully, further research will help answering these questions and enhance our understanding on the role of covenants in financial contracting.

\section{References}

Agarwal, S., I. Ben-David, and V. Yao, 2015, Collateral Valuation and Borrower Financial Constraints: Evidence from the Residential Real Estate Market, Management Science 61(9), 2220-2240.

Aghion, P., and P. Bolton, 1992, An incomplete contracts approach to financial contracting, The Review of Economic Studies 59(3), 473-494.

Aghion, P., M. Dewatripont, and P. Rey, 1994, Renegotiation Design with Unverifiable Information, Econometrica 62, 257-82.

Amiram, D., and E. Owens, 2012, Private Benefits Extraction and the Opposing Effects of Income Smoothing on Private Debt Contracts, Working Paper, Columbia Business School, and Emory University.

Ball, R., R.M. Bushman, and F.P. Vasvari, 2008, The Debt-Contracting Value of Accounting Information and Loan Syndicate Structure, Journal of Accounting Research 46, 247-87.

Beatty, A., J. Weber, and J. Yu, 2008, Conservatism and debt, Journal of Accounting and Economics 45, 154-174.

Beneish, M.D, and E. Press, 1993, Costs of technical violation of accounting-based debt covenants, The Accounting Review 68(2), 233-257.

Beneish, M., and E. Press, 1995, The resolution of technical default, The Accounting Review 70(2), 337-353.

Berger, A.N., and G. Udell, 1995, Relationship Lending and Lines of Credit in Small Firm Finance, The Journal of Business 68(3), 351-81.

Berglöf, E., and E.L. von Thadden, 1994, Short-term versus long-term interests: Capital structure with multiple investors, The Quarterly Journal of Eonomics 109(4), 1055-1084. 
Berlin, M., and L.J. Mester, 1992, Debt covenants and renegotiation, Journal of Financial Intermediation 2(2), 95-133.

Besanko, D., and G. Kanatas, 1993, Credit market equilibrium with bank monitoring and moral hazard, Review of Financial Studies 6(1), 213-232.

Bharath, S. T., S. Dahiya, A. Saunders, and A. Srinivasan, 2011, Lending relationships and loan contract terms, Review of Financial Studies 24 (4), 1141-1203.

Bradley, M., and M. R. Roberts, 2004, The structure and pricing of corporate debt covenants, Working Paper, Duke University, and The Wharton School.

Broecker, T., 1990, Credit worthiness tests and interbank competition, Econometrica 58, 429-452.

Chava, S., and M. R. Roberts, 2008, How does financing impact investment? The role of debt covenants, Journal of Finance 63(5), 2085-2121.

Christensen, H. B., and V. V. Nikolaev, 2012, Capital versus Performance covenants in debt contracts, Journal of Accounting Research 50(1), 75-116.

Christensen, H. B., V. V. Nikolaev, and R. Wittenberg-Moerman, 2015, Accounting Information in Financial Contracting: The Incomplete Contract Theory Perspective, Journal of Accounting Research 54(2), 397-435.

Costello, A. M., and R. Wittenberg-Moerman, 2011, The Impact of Financial Reporting Quality on Debt Contracting: Evidence from Internal Control Weakness Reports, Journal of Accounting Research 49, 97-136.

DeFond, M., and J. Jiambalvo, 1994, Debt covenant violation and manipulation of accruals, Journal of Accounting and Economics 17, 145-176.

Degryse, H., and S. Ongena, 2005, Distance, lending relationships, and competition, Journal of Finance 60(1), 231-266.

Degryse, H., and P. Van Cayseele, 2000, Relationship lending within a bank-based system: Evidence from European small business data, Journal of Financial Intermediation 9(1), 90-109.

Demerjian, P., 2011, Accounting Standards and Debt Covenants: Has the "Balance Sheet Approach" Led to a Decline in the Use of Balance Sheet Covenants?, Journal of Accounting and Economics 52, 178-202.

Demerjian, P., and E. Owens, 2016, Measuring the probability of financial covenant violation in private debt contracts, Journal of Accounting and Economics 61(2-3),433-447.

Demiroglu, C., and C. M. James, 2010, The information content of bank loan covenants, Review of Financial Studies 23(10), 3700-3737.

Denis, D.D, and Jing Wang, 2014, Debt Covenant Renegotiations and Creditor Control Rights, Journal of Financial Economics 113(3), 348-367.

Dewatripont, M., and J. Tirole, 1994, A theory of debt and equity: Diversity of securities and manager-shareholder congruence, The Quarterly Journal of Economics 109(4), 1027-1054.

Diamond, D.W., 1984, Financial intermediation and delegated monitoring, The Review of Economic Studies 51(3), 393-414.

Diamond, D.W., 1991, Monitoring and reputation: the choice between bank loans and directly placed debt, Journal of Political Economy 99(4), 689-721.

Dichev, I.D., and D.J. Skinner, 2002, Large-sample evidence on the debt covenant hypothesis, Journal of Accounting Research 40(4), 1091-1123.

Drucker, S., and M. Puri, 2005, On the benefits of concurrent lending and underwriting, Journal of Finance 60(6), 2763-2799.

Drucker, S., and M. Puri, 2009, On loan sales, loan contracting, and lending relationships, Review of Financial Studies 22(7), 2835-2872.

Dyreng, S., R. Vashishtha, and J. Weber, 2015, Direct Evidence on the Informational Properties of Earnings in Loan Contracts, Working paper, Duke University, and MIT.

Eisfeldt, A.L., and C.M. Kuhnen, 2013, CEO turnover in a competitive assignment framework, Journal of Financial Economics 109(2), 351-372.

El-Gazzar, S., and V. Pastena, 1991, Factors affecting the scope and initial tightness of covenant restrictions in private lending agreements, Contemporary Accounting Research 8(1), 132-151. 
Flannery, M. J., 1994, Debt maturity structure and the deadweight cost of leverage: Optimally financing banking firms, American Economic Review 84(1), 320-331.

Gârleanu, N., and J. Zwiebel, 2009, Design and renegotiation of debt covenants, Review of Financial Studies 22(2), 749-781.

Garmaise, M.J., 2015, Borrower Misreporting and Loan Performance, Journal of Finance 70(1), 449484.

Hollander, S., and A. Verriest, 2016, Bridging the gap: the design of bank loan contracts and distance, Journal of Financial Economics 119(2), 399-419.

Holthausen, R.W., and R.W. Leftwich, 1983, The economic consequences of accounting choice implications of costly contracting and monitoring, Journal of Accounting and Economics 5, $77-117$.

Honigsberg, C., S.P. Katz, S. Mutlu, and G. Sadka, 2015, State Contract Law and the Use of Accounting Information in Debt Contracts, Working paper, Columbia Business School, Kennesaw State University, and University of Texas at Dallas.

Huberman, G., and C. Kahn, 1988, Limited Contract Enforcement and Strategic Renegotiation, American Economic Review 78, 471-84.

Ioannidou, V., and S. Ongena, 2010, "Time for a change": Loan conditions and bank behavior when firms switch banks, Journal of Finance 65(5), 1847-1877.

Jensen, M.C., and W.H. Meckling, 1976, Theory of the firm: Managerial behavior, agency costs, and ownership structure, Journal of Financial Economics 3(4), 305-360.

Kaplan, S.N., and P. Strömberg, 2001, Venture Capitalists as Principals: Contracting, Screening, and Monitoring, American Economic Review 91(2), 426-430.

Kaplan, S.N., and P. Strömberg, 2003, Financial Contracting Theory Meets the Real World: An Empirical Analysis of Venture Capital Contracts, The Review of Economic Studies 70, 281315.

Li, N., F.P. Vasvari, and R. Wittenberg-Moerman, 2015, Dynamic Threshold Values in EarningsBased Covenants, Journal of Accounting and Economics 61(2-3), 605-629.

Liao, S., 2015, Outside blockholders' monitoring of management and debt financing, Contemporary Accounting Research 32(4), 1373-1404.

Leftwich, R., 1983, Accounting Information in Private Markets: Evidence from Private Lending Agreements, The Accounting Review 58, 23-42.

Murfin, J., 2012, The supply-side determinants of loan contract strictness, Journal of Finance 67(5), 1565-1601.

Myers, S.C., 1977, Determinants of corporate borrowing, Journal of Financial Economics 5, 147-175.

Nikolaev, V.V., 2015a, Scope for Renegotiation in Private Debt Contracts, Working Paper, Chicago University.

Nikolaev, V.V., 2015b, Outside Blockholders' Monitoring of Management and Debt Financing: An Alternative Perspective, Contemporary Accounting Research 32(4), 1405-1412.

Nikolaev. V., and L. van Lent, 2005, The endogeneity bias in the relation between cost-of-debt capital and corporate disclosure policy, European Accounting Review 14 (4), 677-724.

Nini, G., D.C. Smith, and A. Sufi, 2009, Creditor control rights and firm investment policy, Journal of Financial Economics 92(3), 400-420.

Nini, G., D.C. Smith, and A. Sufi, 2012, Creditor Control Rights, Corporate Governance, and Firm Value, Review of Financial Studies 25(6), 1713-1761.

O'Brien, P.C., and R. Bhushan, 1990, Analyst Following and Institutional Ownership, Journal of Accounting Research 28, 55-76.

Petersen, M.A., and R.G. Rajan, 1994, The Benefits of Lending Relationships: Evidence from Small Business Data, Journal of Finance 49(1), 3-37.

Prilmeier, R., 2016, Why Do Loans Contain Covenants? Evidence from Lending Relationships, Journal of Financial Economics, forthcoming.

Rajan, R.G., 1992, Insiders and outsiders: The choice between informed and arm's-length debt, Journal of Finance 47(4), 1367-1400. 
Rajan, R.G., and A. Winton, 1995, Covenants and Collateral as Incentives to Monitor, Journal of Finance 50(4), 1113-1146.

Roberts, M.R., 2015, The role of dynamic renegotiation and asymmetric information in financial contracting, Journal of Financial Economics 116(1), 61-81.

Roberts, M.R., and A. Sufi, 2009a, Control rights and capital structure: An empirical investigation, Journal of Finance 64(4), 1657-1695.

Roberts, M.R., and A. Sufi, 2009b, Renegotiation of financial contracts: Evidence from private credit agreements, Journal of Financial Economics 93(2), 159-184.

Rosenbaum, P.R., and D.B. Rubin, 1983, The central role of the propensity score in observational studies for causal effects, Biometrika 70(1), 41-55.

Rubin, D.B., and N. Thomas, 2000, Combining propensity score matching with additional adjustments for prognostic covariates, Journal of the American Statistical Association 95(450), 573-585.

Saunders, A., and S. Steffen, 2011, The costs of being private: Evidence from the loan market, Review of Financial Studies 24(12), 4091-4122.

Sharpe, S.A., 1990, Asymmetric information, bank lending and implicit contracts: A stylized model of customer relationships, Journal of Finance 45(4), 1069-1087.

Shleifer, A., and R. Vishny, 1997, A survey of corporate governance, Journal of Finance 52, 737783.

Smith, C., 1993, A Perspective on Accounting-Based Debt Covenant Violations, The Accounting Review, 289-303.

Smith, C., and J.B. Warner, 1979, On financial contracting: An analysis of bond covenants, Journal of Financial Economics 7(2), 117-161.

Stiglitz, J.E., and A. Weiss, 1983, Incentive effects of terminations: Applications to the credit and labor markets, American Economic Review 73(5), 912-927.

Sweeney, A., 1994, Debt-covenant violations and managers' accounting responses, Journal of Accounting and Economics 17, 281-308.

Watts, R., Zimmerman, J., 1978, Towards a positive theory of the determination of accounting standards, The Accounting Review, 112-134.

Watts, R., Zimmerman, J., 1986, Positive Accounting Theory, Englewood Cliffs, NJ: Prentice Hall.

Zender, J.F., 1991, Optimal Financial Instruments, Journal of Finance 46, 1645-63. 


\section{Figure 1}

Borrower Default Probability after No Covenant Violation and after a Covenant Violation

The figure shows the probability of default for a borrower not violating a financial covenant (Panel A) and for a borrower violating a financial covenant (Panel B). In Panel A, "Days since Past Contract without Violation" denotes the number of days from the end of a loan contract in which no covenant was violated. In Panel B, "Days since Covenant Violation" represents the number of days from a covenant violation in a loan contract.

Panel A: Probability of Default for Borrowers after No Covenant Violation

$$
0.40 \%
$$

$$
0.35 \%
$$

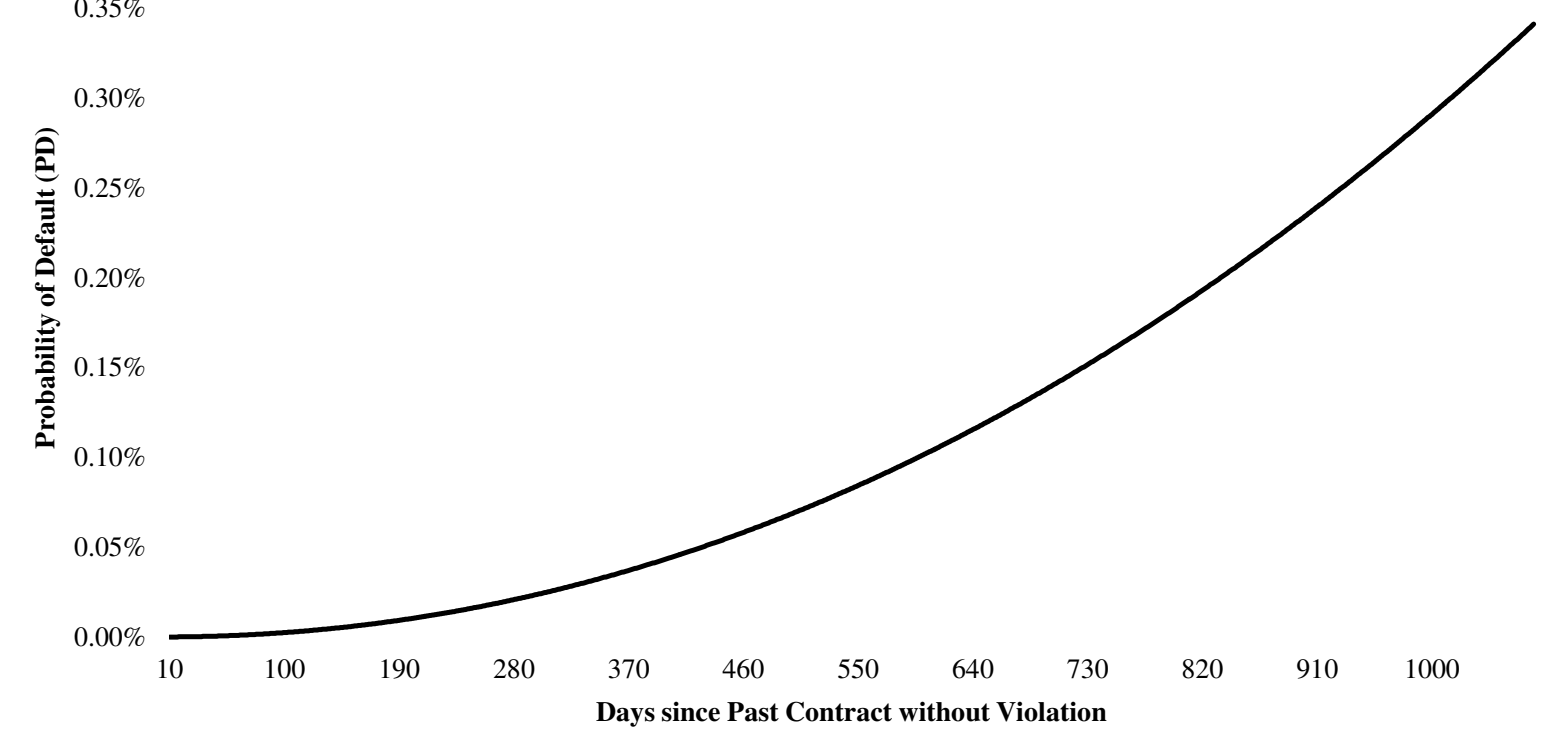

$$
8.00 \%
$$

Panel B: Probability of Default for Borrowers after a Covenant Violation

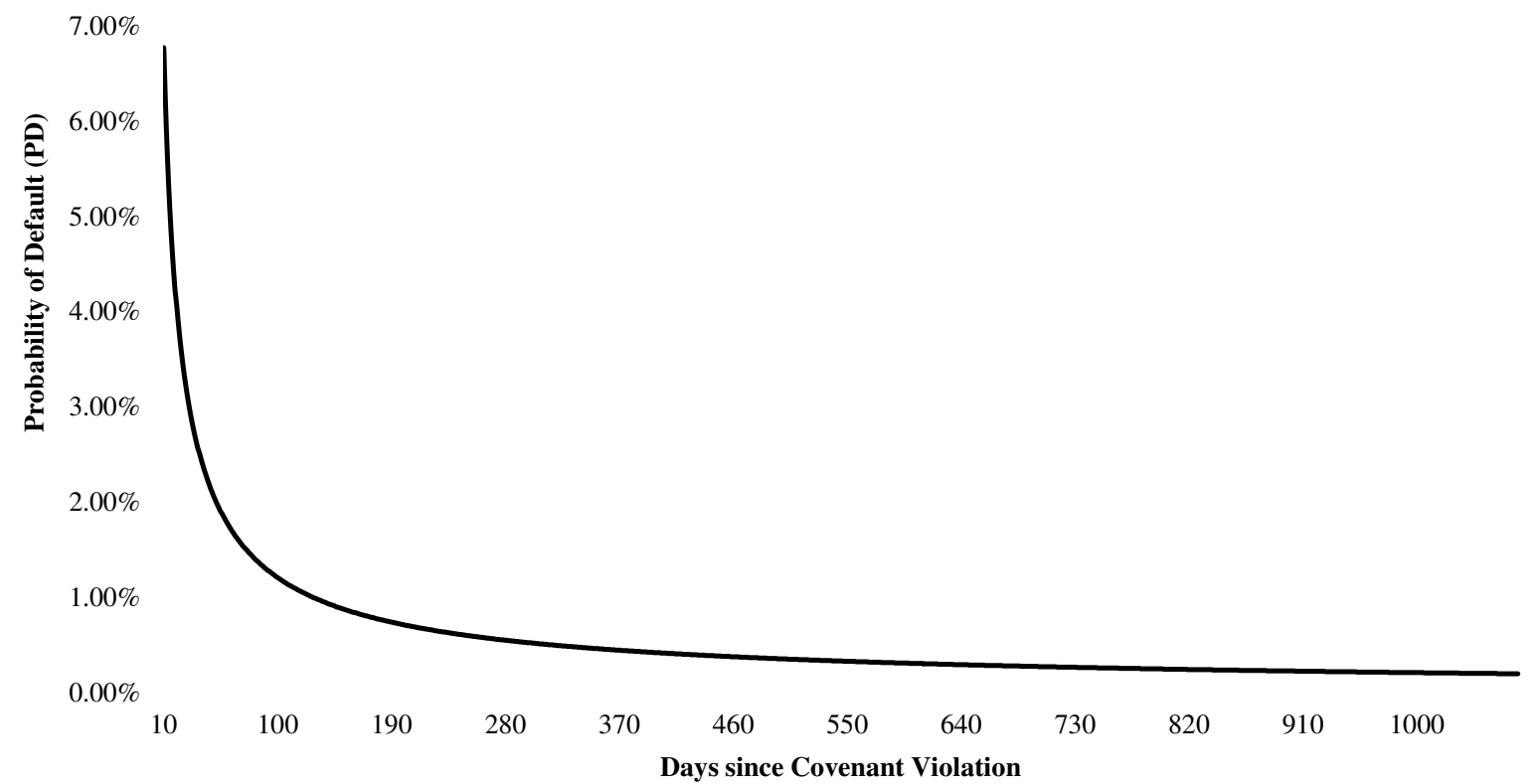




\section{Figure 2}

The Dynamic Effect of Past Covenant Violations on Loan Contract Terms

The figure shows how loan contract terms evolve over the number of loans a borrower obtains. It is split into whether a covenant was violated in the prior loan (1) or not (0). The number of loan observations is shown in parentheses. The loan contract terms are the average All-in-Spread-Drawn (Panel A), the number of financial covenants (Panel $\mathrm{B})$, the average distance to covenant violation (Panel C) and the contract strictness (Panel D). The variables are defined in Appendix I.

Panel A: The Effect of Past Covenant Violations on the All-in-Spread Drawn

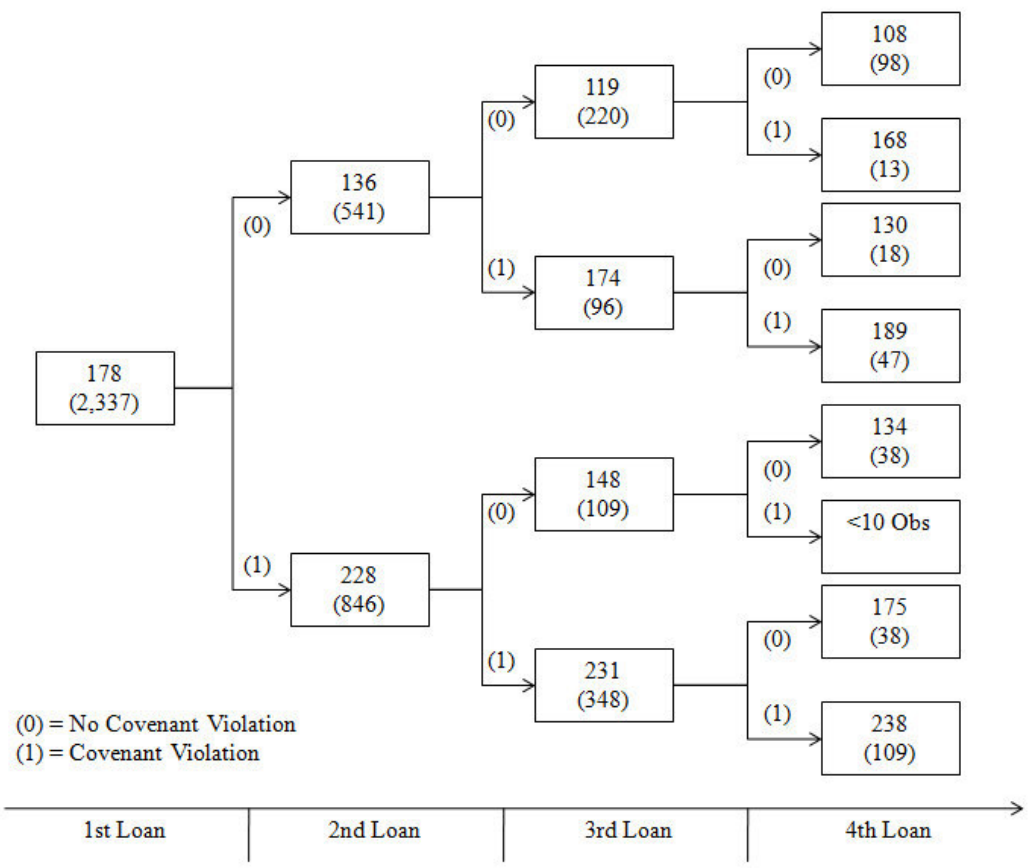

Panel B: The Effect of Past Covenant Violations on the Number of Covenants

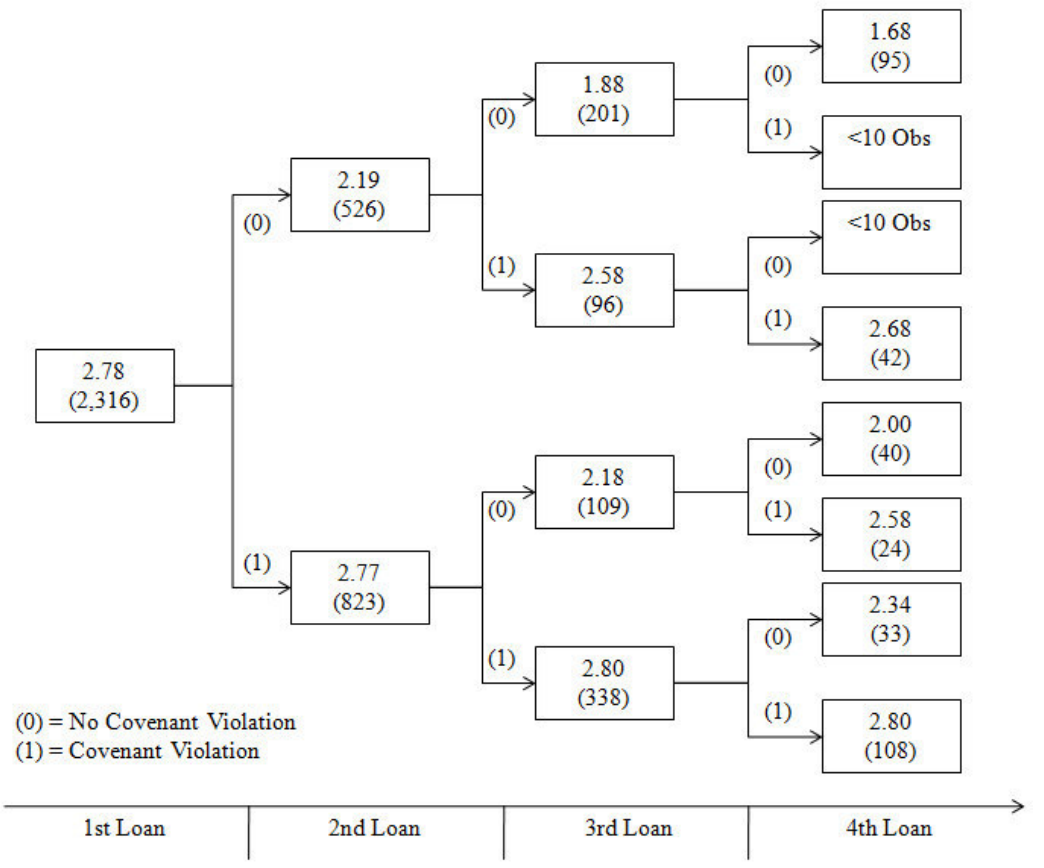




\section{Figure 2 continued}

\section{The Dynamic Effect of Past Covenant Violations on Loan Contract Terms}

Panel C: The Effect of Past Covenant Violations on the Average Distance to Covenant Violation

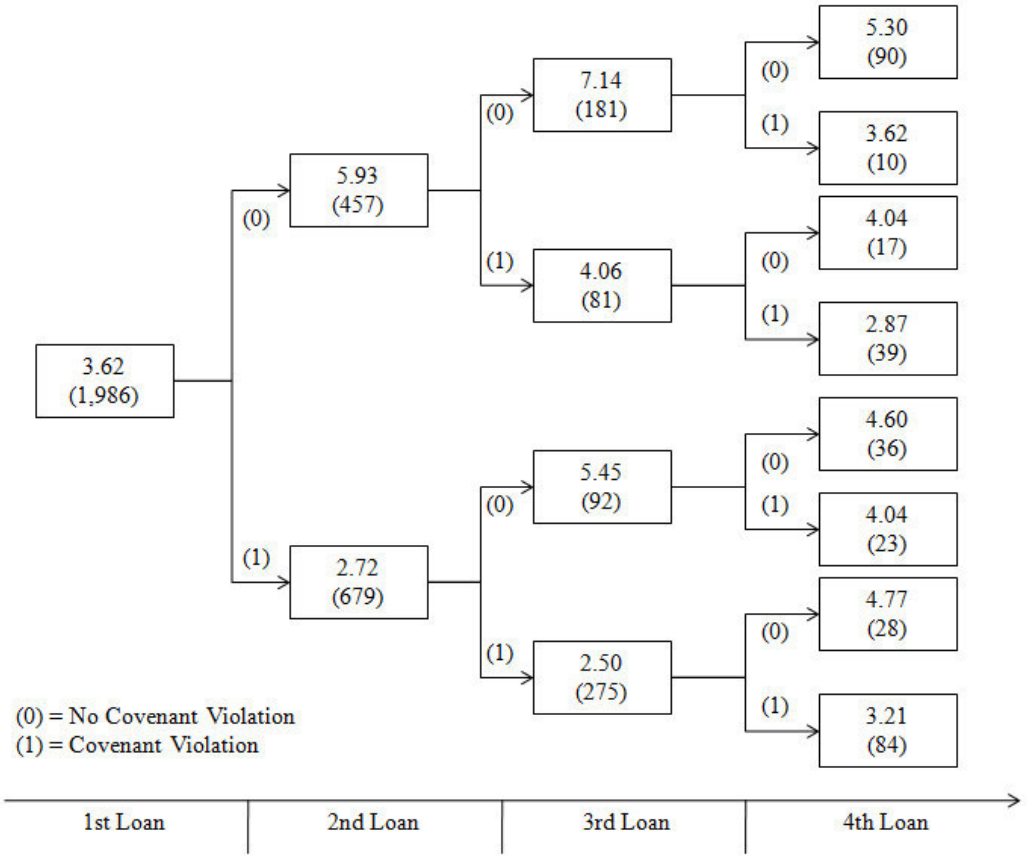

Panel D: The Effect of Past Covenant Violations on the Contract Intensity

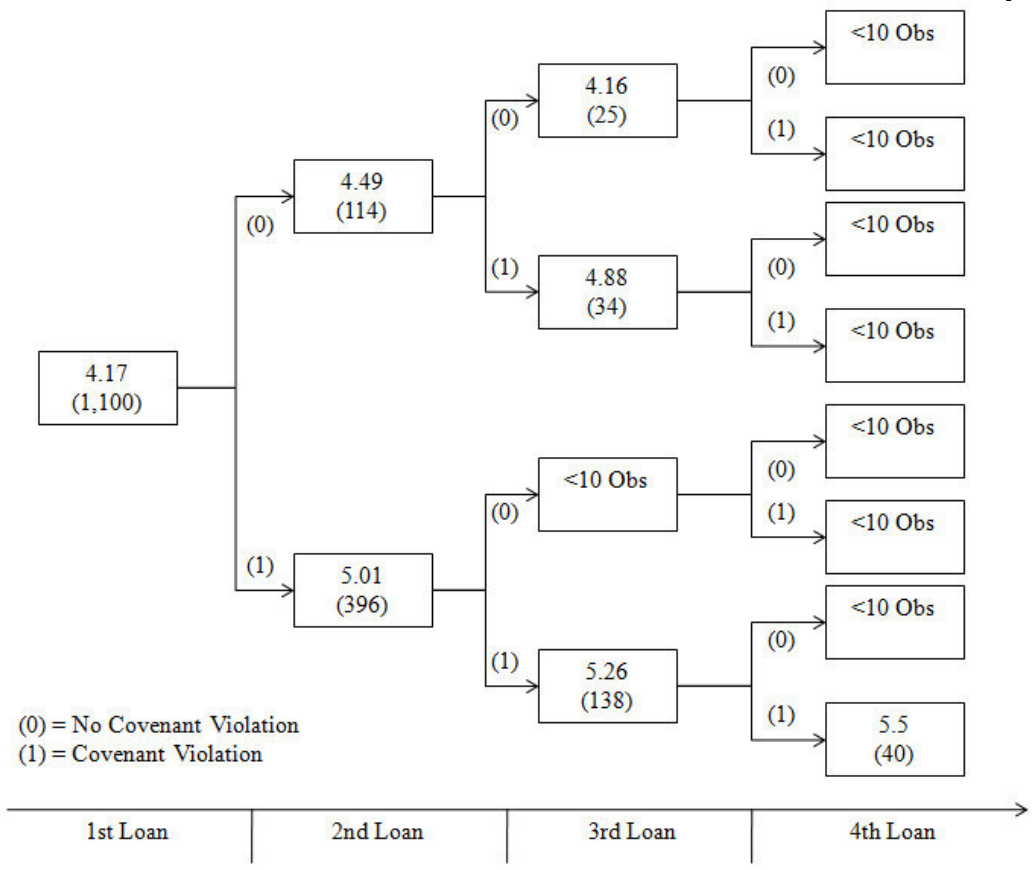




\section{Table I}

\section{Descriptive Statistics}

The table shows descriptive statistics of loan and borrower characteristics for 5,411 loan facilities originated in the 1996 to 2010 period. Borrower data is from the year prior to loan origination. Detailed definitions of the variables are provided in Appendix 1. All variables are winsorized at the 1\% and $99 \%$ level.

\begin{tabular}{|c|c|c|c|c|c|c|}
\hline & Obs. & Mean & Std. Dev. & P 5 & Median & P 95 \\
\hline \multicolumn{7}{|l|}{ Panel A: Dependent Variables } \\
\hline All-in-Spread-Drawn & 5,315 & 183 & 124 & 30 & 162 & 400 \\
\hline Number of Financial Covenants & 5,163 & 2.55 & 1.16 & 1 & 2 & 4 \\
\hline Average DCV & 4,378 & 3.95 & 5.75 & 0.25 & 2.32 & 12.21 \\
\hline $\mathrm{DCV}$ & 4,378 & 2.58 & 8.43 & 0.04 & 1.25 & 7.78 \\
\hline Contract Intensity Index & 1,985 & 4.55 & 1.66 & 1 & 5 & 6 \\
\hline Capital Covenants & 5,163 & $57.7 \%$ & $49.4 \%$ & - & - & - \\
\hline Profitability Covenants & 5,163 & $87.5 \%$ & $33.0 \%$ & - & - & - \\
\hline Contract Violation & 5,163 & $55.0 \%$ & $49.8 \%$ & - & - & - \\
\hline Days to Contract Violation & 3,023 & 427 & 397 & 96 & 288 & 1223 \\
\hline Default & 5,411 & $2.5 \%$ & $15.7 \%$ & - & - & - \\
\hline Switch & 5,346 & $35.1 \%$ & $47.7 \%$ & - & - & - \\
\hline \multicolumn{7}{|l|}{ Panel B: Independent Variables } \\
\hline \multicolumn{7}{|l|}{ B.1 Loan Characteristics } \\
\hline Prior Covenant Violation & 2,971 & $57.2 \%$ & $49.5 \%$ & - & - & - \\
\hline Number of Covenants Violated & 1,699 & 2.07 & 1.05 & - & - & - \\
\hline Percentage of Covenants Violated & 1,699 & $72.7 \%$ & 0.27 & - & - & - \\
\hline Days Violation to Subsequent Loan & 1,699 & 1,091 & 728 & 231 & 918 & 2,457 \\
\hline Facility Size (Year 2000 USD mm) & 5,411 & 298 & 415 & 11 & 151 & 1,139 \\
\hline Maturity (Months) & 5,349 & 48 & 22 & 12 & 57 & 84 \\
\hline Secured & 5,371 & $63.6 \%$ & $48.1 \%$ & - & - & - \\
\hline Number of Loans & 5,411 & 7.91 & 6.06 & 2 & 6 & 19 \\
\hline Performance Pricing & 5,411 & $68.8 \%$ & $46.3 \%$ & - & - & - \\
\hline \multicolumn{7}{|l|}{ Loan Purpose in $\%$ of Firms } \\
\hline$\overline{\text { Corporate }}$ & 5,411 & $45.7 \%$ & $49.8 \%$ & - & - & - \\
\hline Recapitalization & 5,411 & $21.5 \%$ & $41.1 \%$ & - & - & - \\
\hline Acquisition & 5,411 & $19.9 \%$ & $39.9 \%$ & - & - & - \\
\hline Back Up & 5,411 & $6.5 \%$ & $24.7 \%$ & - & - & - \\
\hline Other & 5,411 & $4.9 \%$ & $21.6 \%$ & - & - & - \\
\hline LBO & 5,411 & $1.6 \%$ & $12.4 \%$ & - & - & - \\
\hline \multicolumn{7}{|l|}{ Loan Type in \% of Firms } \\
\hline Revolver $\geq 1$ Year & 5,411 & $60.2 \%$ & $49.0 \%$ & - & - & - \\
\hline Term Loans & 5,411 & $26.3 \%$ & $44.0 \%$ & - & - & - \\
\hline 364 - Day Facility & 5,411 & $9.1 \%$ & $28.7 \%$ & - & - & - \\
\hline Revolver $<1$ Year & 5,411 & $2.1 \%$ & $14.2 \%$ & - & - & - \\
\hline Bridge Loan & 5,411 & $1.6 \%$ & $12.6 \%$ & - & - & - \\
\hline \multicolumn{7}{|l|}{ B.2 Borrower Characteristics } \\
\hline Total Assets (Year 2000 USD mm) & 5,409 & 3,291 & 6,667 & 65 & 854 & 17,155 \\
\hline Profitability & 5,376 & 0.17 & 0.14 & 0.01 & 0.14 & 0.46 \\
\hline Current Ratio & 5,333 & 1.84 & 1.12 & 0.58 & 1.59 & 3.83 \\
\hline Leverage & 5,401 & 0.33 & 0.22 & 0.007 & 0.30 & 0.73 \\
\hline Coverage & 5,241 & 15.44 & 40.75 & 0.39 & 4.48 & 66.67 \\
\hline 5 year Profit Trend & 5,389 & -0.01 & 2.93 & -4.05 & -0.12 & 4.53 \\
\hline Market to Book & 5,330 & 1.68 & 0.89 & 0.85 & 1.40 & 3.45 \\
\hline Borrower IPO (Years) & 4,476 & 45 & 46 & 1.61 & 12.96 & 104.96 \\
\hline \multicolumn{7}{|l|}{ Credit Rating } \\
\hline Investment Grade Rating & 5,411 & $24.1 \%$ & $42.8 \%$ & - & - & - \\
\hline Non-Investment Grade Rating & 5,411 & $34.5 \%$ & $47.5 \%$ & - & - & - \\
\hline Not Rated & 5,411 & $41.4 \%$ & $49.3 \%$ & - & - & - \\
\hline
\end{tabular}




\section{Table I continued Descriptive Statistics}

\begin{tabular}{|c|c|c|c|c|c|c|}
\hline \multirow{2}{*}{\multicolumn{2}{|c|}{ Panel C: Distribution of Covenants }} & \multirow[t]{2}{*}{ Mean } & \multirow[t]{2}{*}{ Std. Dev. } & \multicolumn{3}{|c|}{ Loan Amount (\$Bil) } \\
\hline & & & & Average & Median & Total \\
\hline Debt to EBITDA & 5,163 & $61.70 \%$ & $48.60 \%$ & 0.27 & 0.14 & 860 \\
\hline Interest Coverage & 5,163 & $44.30 \%$ & $49.70 \%$ & 0.34 & 0.19 & 778 \\
\hline Fixed Charge Coverage & 5,163 & $41.70 \%$ & $49.30 \%$ & 0.18 & 0.1 & 388 \\
\hline Net Worth & 5,163 & $23.80 \%$ & $42.60 \%$ & 0.26 & 0.13 & 319 \\
\hline Debt to Capitalization & 5,163 & $20.00 \%$ & $40.00 \%$ & 0.39 & 0.22 & 403 \\
\hline Tangible Net Worth & 5,163 & $14.40 \%$ & $35.10 \%$ & 0.16 & 0.07 & 119 \\
\hline Senior Debt to EBITDA & 5,163 & $13.30 \%$ & $34.00 \%$ & 0.22 & 0.14 & 151 \\
\hline EBITDA & 5,163 & $11.90 \%$ & $32.40 \%$ & 0.11 & 0.05 & 68 \\
\hline Current Ratio & 5,163 & $6.90 \%$ & $25.30 \%$ & 0.14 & 0.07 & 50 \\
\hline Debt Service Coverage & 5,163 & $4.60 \%$ & $21.00 \%$ & 0.17 & 0.08 & 40 \\
\hline Debt to Net Worth & 5,163 & $4.10 \%$ & $19.90 \%$ & 0.42 & 0.06 & 88 \\
\hline Quick Ratio & 5,163 & $1.80 \%$ & $13.40 \%$ & 0.08 & 0.04 & 7 \\
\hline Asset Coverage Ratio & 5,163 & $1.60 \%$ & $12.60 \%$ & 0.19 & 0.14 & 16 \\
\hline Cash and Cash Equivalents & 5,163 & $1.10 \%$ & $10.60 \%$ & 0.21 & 0.05 & 12 \\
\hline Senior Debt to Capitalization & 5,163 & $0.90 \%$ & $9.40 \%$ & 0.33 & 0.11 & 15 \\
\hline Working Capital & 5,163 & $0.80 \%$ & $8.80 \%$ & 0.1 & 0.05 & 4 \\
\hline \multirow[t]{2}{*}{ Senior Debt to Net Worth } & 5,163 & $0.30 \%$ & $5.70 \%$ & 0.11 & 0.05 & 2 \\
\hline & Obs. & Mean & Std. Dev. & \multicolumn{3}{|c|}{ Loan Amount (\$Bil) } \\
\hline \multicolumn{3}{|c|}{ Panel D: Profitability vs. Capital Covenants } & & Average & Median & Total \\
\hline Capital Covenants & 5,163 & 0.58 & 0.49 & 0.29 & 0.13 & 859 \\
\hline Profitability Covenants & 5,163 & 0.88 & 0.33 & 0.28 & 0.14 & 1,269 \\
\hline
\end{tabular}




\section{Table II}

\section{Descriptive Statistics by Covenant Violation in the Prior Loan Contract}

The table shows the mean and median of loan contract terms, and loan and borrower characteristics for granted loans in the time period 1996 to 2010 split into whether a covenant was violated in the prior loan ("Violation") or no covenant violation ("No Violation") occurred. The statistical significance of the difference between "Violation" and "No Violation" of each variable is tested via a t-test and a Wilcoxon rank sum test where the last two columns provide the corresponding $\mathrm{t}$ - and $\mathrm{z}$-statistic. All variables are defined in Appendix 1. The statistical significance of results is indicated by $*=10 \%$ level, $* *=5 \%$ level and $* * *=1 \%$ level.

\begin{tabular}{|c|c|c|c|c|c|c|}
\hline & \multirow{2}{*}{\multicolumn{2}{|c|}{$\begin{array}{c}\text { No Violation } \\
(A) \\
\end{array}$}} & \multirow{2}{*}{\multicolumn{2}{|c|}{$\begin{array}{c}\text { Violation } \\
\text { (B) }\end{array}$}} & \multirow{2}{*}{\multicolumn{2}{|c|}{$(A)-(B)$}} \\
\hline & & & & & & \\
\hline & Mean & Median & Mean & Median & t-statistics & z-statistics \\
\hline \multicolumn{7}{|l|}{ Panel A: Dependent Variables } \\
\hline Default & 0.008 & 0 & 0.041 & 0 & $-5.350 * * *$ & $-5.330 * * *$ \\
\hline All-in-Spread-Drawn & 131 & 100 & 229 & 220 & $-21.920 * * *$ & $-23.140 * * *$ \\
\hline Number of Financial Covenants & 2.02 & 2 & 2.62 & 3 & $-15.030 * * *$ & $-14.600 * * *$ \\
\hline Average DCV & 5.82 & 3.76 & 2.84 & 1.78 & $13.108 * * *$ & $18.101 * * *$ \\
\hline DCV & 3.96 & 2.67 & 1.64 & 1.01 & $12.861 * * *$ & $17.381 * * *$ \\
\hline Contract Intensity Index & 4.57 & 5 & 5.12 & 5 & $-5.340 * * *$ & $-4.430 * * *$ \\
\hline Capital Covenants & 0.66 & 1 & 0.56 & 0 & $4.225 * * *$ & $5.107 * * *$ \\
\hline Profitability Covenants & 1.31 & 1 & 2.01 & 2 & $-18.508 * * *$ & $-16.848 * * *$ \\
\hline Switch & 0.20 & 0 & 0.28 & 0 & $-5.160 * * *$ & $-5.140 * * *$ \\
\hline \multicolumn{7}{|l|}{ Panel B: Independent Variables } \\
\hline \multicolumn{7}{|l|}{ B.1 Loan Characteristics } \\
\hline Facility Size (Year 2000 USD mm) & 428 & 252 & 287 & 155 & $8.670 * * *$ & $10.600 * * *$ \\
\hline Maturity (Months) & 44.0 & 50.0 & 51.0 & 60.0 & $-8.730 * * *$ & $-7.520 * * *$ \\
\hline Secured & 0.40 & 0 & 0.79 & 1 & $-23.200 * * *$ & $-21.330 * * *$ \\
\hline Number of Loans & 10.46 & 9 & 9.44 & 8 & $4.286 * * *$ & $4.796 * * *$ \\
\hline Performance Pricing & 0.73 & 1 & 0.63 & 1 & $6.273 * * *$ & $6.232 * * *$ \\
\hline \multicolumn{7}{|l|}{ Loan Purpose in \% of Firms } \\
\hline Corporate & 0.61 & 1 & 0.48 & 0 & $7.340 * * *$ & $7.270 * * *$ \\
\hline Recapitalization & 0.10 & 0 & 0.16 & 0 & $-4.430 * * *$ & $-4.410 * * *$ \\
\hline Acquisition & 0.09 & 0 & 0.25 & 0 & $-11.530 * * *$ & $-11.280^{* * *}$ \\
\hline Back Up & 0.12 & 0 & 0.02 & 0 & $11.090 * * *$ & $10.870 * * *$ \\
\hline Other & 0.04 & 0 & 0.05 & 0 & -1.64 & -1.64 \\
\hline LBO & 0.02 & 0 & 0.02 & 0 & -0.51 & -0.51 \\
\hline \multicolumn{7}{|l|}{ Loan Type in $\%$ of Firms } \\
\hline Revolver $\geq 1$ Year & 0.64 & 1 & 0.56 & 1 & $4.380 * * *$ & $4.360 * * *$ \\
\hline Term Loans & 0.16 & 0 & 0.36 & 0 & $-11.680 * * *$ & $-11.430 * * *$ \\
\hline 364 - Day Facility & 0.15 & 0 & 0.04 & 0 & $9.910 * * *$ & $9.750 * * *$ \\
\hline Revolver $<1$ Year & 0.02 & 0 & 0.02 & 0 & 0.48 & 0.48 \\
\hline Bridge Loan & 0.02 & 0 & 0.02 & 0 & 0.77 & 0.77 \\
\hline \multicolumn{7}{|l|}{ B.2 Borrower Characteristics } \\
\hline Total Assets (Year 2000 USD mm) & 5,737 & 2,161 & 2,938 & 907 & $10.510 * * *$ & $13.530 * * *$ \\
\hline Profitability & 0.18 & 0.16 & 0.17 & 0.14 & $1.920 * *$ & $3.510^{* * *}$ \\
\hline Current Ratio & 1.68 & 1.50 & 1.71 & 1.53 & -0.98 & -1.37 \\
\hline Leverage & 0.28 & 0.26 & 0.38 & 0.37 & $-13.470 * * *$ & $-13.800 * * *$ \\
\hline Coverage & 17.96 & 6.68 & 10.01 & 3.57 & $6.460 * * *$ & $15.550 * * *$ \\
\hline 5 year Profit Trend & 0.14 & 0.01 & -0.11 & -0.12 & $2.263 * *$ & $4.282 * * *$ \\
\hline Market to Book & 1.68 & 1.41 & 1.57 & 1.33 & $6.740 * * *$ & $5.990 * * *$ \\
\hline Borrower IPO (Years) & 50 & 17 & 42 & 13 & $4.640 * * *$ & $6.240 * * *$ \\
\hline \multicolumn{7}{|l|}{ Credit Rating } \\
\hline Investment Grade Rating & 0.47 & 0 & 0.13 & 0 & $21.530 * * *$ & $20.030 * * *$ \\
\hline Non-Investment Grade Rating & 0.24 & 0 & 0.53 & 1 & $-16.850 * * *$ & $-16.100 * * *$ \\
\hline Not Rated & 0.29 & 0 & 0.34 & 0 & $-2.290 * *$ & $-2.280 * *$ \\
\hline
\end{tabular}




\section{Table III}

\section{Dynamic Loan Contracting Following Covenant Violations in the Prior Loan}

The table reports results from multivariate regressions of various price and non-price loan contract terms on prior covenant violation and control variables. These are the (1) All-in-Spread-Drawn, (2) the number of financial covenants, (3) the average distance to covenant violation (DCV), (4) the DCV, and (5) the contract intensity. Prior covenant violation is a dummy variable equal to one if the borrower violated a financial covenant in the prior loan contract. All variables are described in Appendix 1. In Model (5) "Secured" is excluded as it is part of the dependent variable. Panel B uses the same specification as Panel A and additionally includes borrower fixed effects. Standard errors shown in parentheses are robust to heteroscedasticity and clustered at the firm level. The statistical significance of results is indicated by $*=10 \%$ level, $* *=5 \%$ level and $* * *=1 \%$ level.

\begin{tabular}{|c|c|c|c|c|c|}
\hline Panel A & (1) & (2) & (3) & (4) & (5) \\
\hline Dependent Variable & AISD & $\begin{array}{c}\text { Covenant } \\
\text { Number } \\
\end{array}$ & Average DCV & DCV & $\begin{array}{l}\text { Contract } \\
\text { Intensity }\end{array}$ \\
\hline Regression Methodology & OLS & Ordered Logit & OLS & OLS & Ordered Logit \\
\hline Prior Covenant Violation & $\begin{array}{c}17.716^{* * * *} \\
(3.892)\end{array}$ & $\begin{array}{c}0.413 \text { *** } \\
(0.108)\end{array}$ & $\begin{array}{c}-1.521 * * * \\
(0.343)\end{array}$ & $\begin{array}{c}-1.057 * * * \\
(0.208)\end{array}$ & $\begin{array}{l}0.458 * \\
(0.241)\end{array}$ \\
\hline \multicolumn{6}{|l|}{ Loan Characteristics } \\
\hline Ln(Maturity in Months) & $\begin{array}{c}-14.028^{* *} \\
(6.204)\end{array}$ & $\begin{array}{c}0.371^{* *} \\
(0.148)\end{array}$ & $\begin{array}{l}0.514^{*} \\
(0.275)\end{array}$ & $\begin{array}{c}0.094 \\
(0.194)\end{array}$ & $\begin{array}{c}0.680 \text { **** } \\
(0.230)\end{array}$ \\
\hline Secured & $\begin{array}{c}51.577 * * * \\
(5.533)\end{array}$ & $\begin{array}{c}0.014 \\
(0.130)\end{array}$ & $\begin{array}{l}-0.913 * \\
(0.471)\end{array}$ & $\begin{array}{l}-0.413 \\
(0.359)\end{array}$ & \\
\hline Log (Facility Size) & $\begin{array}{c}-12.322 * * * \\
(2.373)\end{array}$ & $\begin{array}{c}0.023 \\
(0.057)\end{array}$ & $\begin{array}{l}-0.258^{*} \\
(0.136)\end{array}$ & $\begin{array}{c}-0.276^{* *} \\
(0.139)\end{array}$ & $\begin{array}{l}-0.156 \\
(0.127)\end{array}$ \\
\hline Ln(Number of Loans) & $\begin{array}{c}4.108 \\
(4.205)\end{array}$ & $\begin{array}{l}-0.213 \\
(0.131)\end{array}$ & $\begin{array}{l}-0.130 \\
(0.375)\end{array}$ & $\begin{array}{l}-0.256 \\
(0.254)\end{array}$ & $\begin{array}{l}-0.253 \\
(0.281)\end{array}$ \\
\hline Performance Pricing & $\begin{array}{c}-39.961 * * * \\
(4.691)\end{array}$ & $\begin{array}{c}0.354^{* * * *} \\
(0.123)\end{array}$ & $\begin{array}{c}0.494 * * \\
(0.246)\end{array}$ & $\begin{array}{c}0.047 \\
(0.192)\end{array}$ & $\begin{array}{c}0.160 \\
(0.232)\end{array}$ \\
\hline \multicolumn{6}{|l|}{ Borrower Characteristics } \\
\hline Profitability & $\begin{array}{c}-0.539 * * \\
(0.230)\end{array}$ & $\begin{array}{c}0.005 \\
(0.005)\end{array}$ & $\begin{array}{l}-0.007 \\
(0.013)\end{array}$ & $\begin{array}{c}0.006 \\
(0.006)\end{array}$ & $\begin{array}{c}0.010 \\
(0.009)\end{array}$ \\
\hline Current Ratio & $\begin{array}{c}-0.064 * * * \\
(0.025)\end{array}$ & $\begin{array}{c}0.001 \\
(0.001)\end{array}$ & $\begin{array}{l}0.004 * \\
(0.002)\end{array}$ & $\begin{array}{c}0.001 \\
(0.002)\end{array}$ & $\begin{array}{l}-0.002 \\
(0.001)\end{array}$ \\
\hline Leverage & $\begin{array}{c}0.684 * * * \\
(0.145)\end{array}$ & $\begin{array}{c}0.003 \\
(0.004)\end{array}$ & $\begin{array}{c}-0.026 * * * * \\
(0.009)\end{array}$ & $\begin{array}{c}-0.024 * * * \\
(0.006)\end{array}$ & $\begin{array}{c}0.002 \\
(0.006)\end{array}$ \\
\hline Coverage & $\begin{array}{c}-0.001 * * \\
(0.001)\end{array}$ & $\begin{array}{c}0.000 \\
(0.000)\end{array}$ & $\begin{array}{c}0.000 * * * \\
(0.000)\end{array}$ & $\begin{array}{c}0.000 \\
(0.000)\end{array}$ & $\begin{array}{c}0.000^{* * *} \\
(0.000)\end{array}$ \\
\hline 5 year Profit Trend & $\begin{array}{c}0.110 \\
(0.984)\end{array}$ & $\begin{array}{c}0.011 \\
(0.025)\end{array}$ & $\begin{array}{l}-0.032 \\
(0.045)\end{array}$ & $\begin{array}{l}-0.051 \\
(0.032)\end{array}$ & $\begin{array}{l}-0.043 \\
(0.034)\end{array}$ \\
\hline Market to Book & $\begin{array}{c}-0.119 * * * \\
(0.028)\end{array}$ & $\begin{array}{c}0.000 \\
(0.001)\end{array}$ & $\begin{array}{c}0.002 \\
(0.003)\end{array}$ & $\begin{array}{c}0.006 * * * \\
(0.002)\end{array}$ & $\begin{array}{c}-0.005^{* * * *} \\
(0.002)\end{array}$ \\
\hline Log (Total Assets) & $\begin{array}{c}-5.219^{*} \\
(2.812)\end{array}$ & $\begin{array}{c}-0.377 * * * \\
(0.074)\end{array}$ & $\begin{array}{l}0.376^{*} \\
(0.220)\end{array}$ & $\begin{array}{c}0.541 * * * \\
(0.174)\end{array}$ & $\begin{array}{l}-0.212 \\
(0.151)\end{array}$ \\
\hline Constant & $\begin{array}{c}483.372 * * * \\
(41.437) \\
\end{array}$ & YES & $\begin{array}{c}17.451 * * * \\
(4.126) \\
\end{array}$ & $\begin{array}{c}1.024 \\
(2.384) \\
\end{array}$ & YES \\
\hline Year Fixed Effects & YES & YES & YES & YES & YES \\
\hline Industry Fixed Effects & YES & YES & YES & YES & YES \\
\hline Rating Fixed Effects & YES & YES & YES & YES & YES \\
\hline Loan Type Fixed Effects & YES & YES & YES & YES & YES \\
\hline Loan Purpose Fixed Effects & YES & YES & YES & YES & YES \\
\hline Number of Observations & 2,786 & 2,709 & 2,272 & 2,272 & 848 \\
\hline $\mathrm{R}^{2}$ & 0.664 & 0.165 & 0.221 & 0.179 & 0.186 \\
\hline
\end{tabular}


Table III continued

Dynamic Loan Contracting Following Covenant Violations in the Prior Loan

\begin{tabular}{|c|c|c|c|c|c|}
\hline Panel B: Including Borrower Fixed Effects & (1) & (2) & (3) & (3) & (4) \\
\hline Dependent Variable & AISD & $\begin{array}{l}\text { Covenant } \\
\text { Number }\end{array}$ & Average DCV & DCV & $\begin{array}{l}\text { Contract } \\
\text { Intensity }\end{array}$ \\
\hline Regression Methodology & OLS & Ordered Logit & OLS & OLS & Ordered Logit \\
\hline Prior Covenant Violation & $\begin{array}{c}7.698^{* *} \\
(3.143)\end{array}$ & $\begin{array}{c}0.176^{* *} \\
(0.074)\end{array}$ & $\begin{array}{c}-1.383^{* * * *} \\
(0.265)\end{array}$ & $\begin{array}{c}-0.858^{* * * *} \\
(0.154)\end{array}$ & $\begin{array}{l}-0.130 \\
(0.217)\end{array}$ \\
\hline Loan Characteristics & YES & YES & YES & YES & YES \\
\hline Borrower Characteristics & YES & YES & YES & YES & YES \\
\hline Borrower Fixed Effects & YES & YES & YES & YES & YES \\
\hline Year Fixed Effects & YES & YES & YES & YES & YES \\
\hline Industry Fixed Effects & YES & YES & YES & YES & YES \\
\hline Rating Fixed Effects & YES & YES & YES & YES & YES \\
\hline Loan Type Fixed Effects & YES & YES & YES & YES & YES \\
\hline Loan Purpose Fixed Effects & YES & YES & YES & YES & YES \\
\hline Number of Observations & 2,786 & 2,709 & 2,272 & 2,272 & 848 \\
\hline $\mathrm{R}^{2}$ & 0.853 & 0.580 & 0.752 & 0.715 & 0.761 \\
\hline
\end{tabular}




\section{Table IV}

Dynamic Loan Contracting Following Covenant Violations in the Prior Loan - Alternative Explanations - Credit Risk

The table reports results from multivariate regressions of different dependent variables. These are a default indicator variable (Panel A), a rating downgrade indicator variable (Panel B), the change in firm net worth to total assets (Panel C), the change in firm leverage (Panel D), the number of subsequent loss making quarters excluding the current quarter (Panel E), and the (1) All-in-Spread-Drawn, (2) the number of financial covenants, (3) the average distance to covenant violation (DCV), (4) the DCV, and (5) the contract intensity (Panel F). Borrower and loan characteristics are as in Table III. Covenant Violation in Panels A to E is a dummy variable equal to one if the borrower violates a financial covenant in year t. Panels A to $\mathrm{F}$ use annual data where for the determination of the dependent variable in Panel E we use quarterly data. Prior covenant violation in Panel F is a dummy variable equal to one if the borrower violated a financial covenant in the prior loan contract. Model (1) in Panels A and B reports results from a Cox proportional hazards model. The remaining models in both Panels show regressions of the respective dependent variable on (lagged) control variables. Panels $\mathrm{C}$ and $\mathrm{D}$ show regressions of differences of the respective dependent variable between year $\mathrm{t}+\mathrm{x}$ and year $t$ on control variables in year $\mathrm{t}-1$. Panel $\mathrm{E}$ uses the number of subsequent loss making quarters as dependent variable excluding the current quarter. In years with no financial covenant violation this is the number of loss making quarters after Q4 of the respective year, in years with financial covenant violation the control variables are used in Q4 of the previous year and the number of loss making quarters is calculated as the loss quarters after the violation. Panel F reports results as in Table III but excludes all overlapping loans of each borrower, that is, new loans that are originated while existing loans have not yet matured. In Models (5) and (10) "Secured" is excluded as it is part of the dependent variable. All variables are described in Appendix 1. Standard errors shown in parentheses are robust to heteroscedasticity and clustered at the firm level. The statistical significance of results is indicated by $*=10 \%$ level, $* *=5 \%$ level and $* * *=1 \%$ level. 


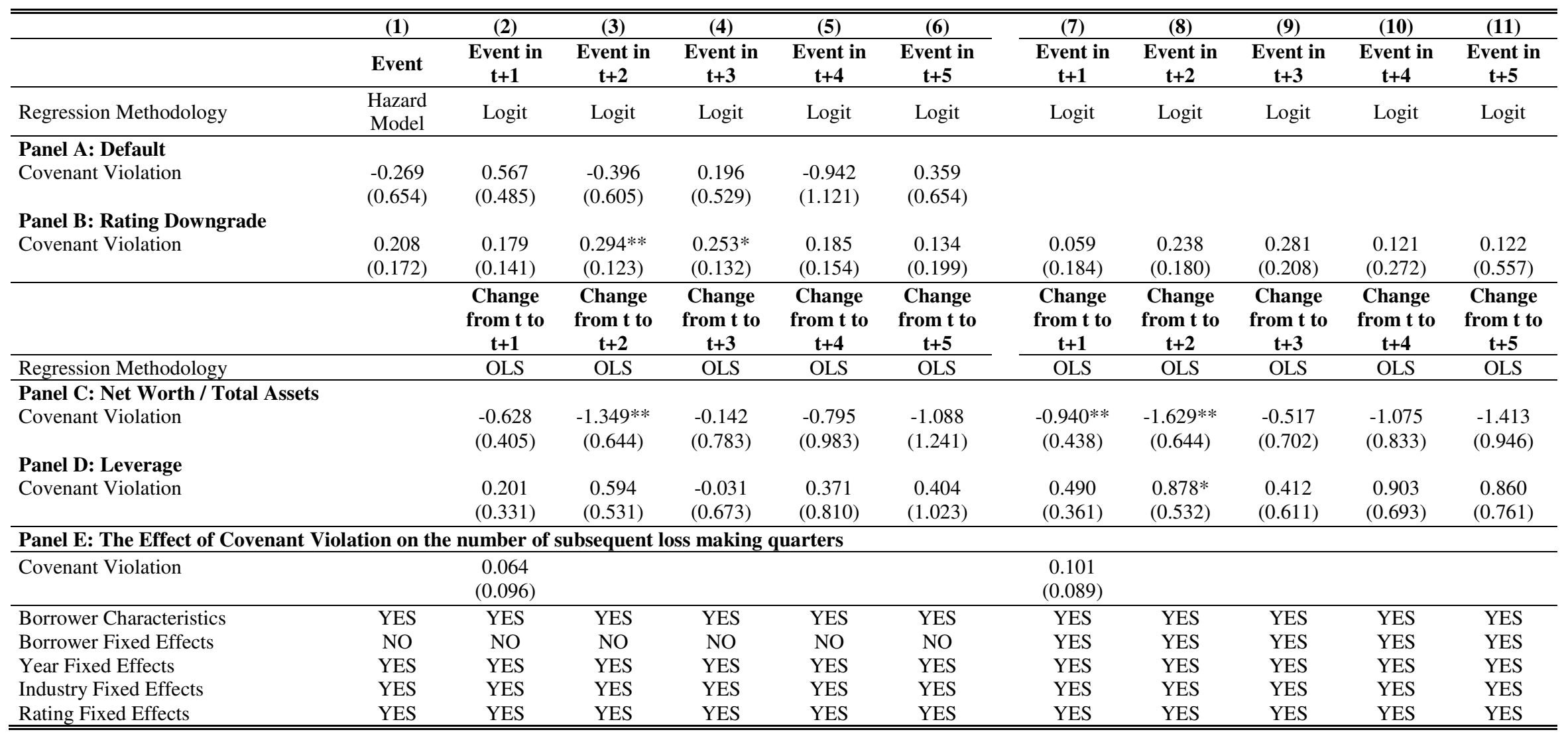


Table IV continued

Dynamic Loan Contracting Following Covenant Violations in the Prior Loan - Alternative Explanations - Credit Risk

\begin{tabular}{|c|c|c|c|c|c|c|c|c|c|c|}
\hline Panel F: Excluding Overlapping Loans & (1) & (2) & (3) & (4) & (5) & (6) & (7) & (8) & (9) & (10) \\
\hline Dependent Variable & AISD & $\begin{array}{l}\text { Covenant } \\
\text { Number }\end{array}$ & $\begin{array}{c}\text { Average } \\
\text { DCV }\end{array}$ & DCV & $\begin{array}{l}\text { Contract } \\
\text { Intensity }\end{array}$ & AISD & $\begin{array}{l}\text { Covenant } \\
\text { Number }\end{array}$ & $\begin{array}{c}\text { Average } \\
\text { DCV }\end{array}$ & DCV & $\begin{array}{l}\text { Contrac } \\
\text { Intensity }\end{array}$ \\
\hline Regression Methodology & OLS & $\begin{array}{c}\text { Ordered } \\
\text { Logit }\end{array}$ & OLS & & $\begin{array}{c}\text { Ordered } \\
\text { Logit }\end{array}$ & OLS & $\begin{array}{c}\text { Ordered } \\
\text { Logit }\end{array}$ & OLS & & $\begin{array}{c}\text { Ordered } \\
\text { Logit }\end{array}$ \\
\hline Prior Covenant Violation & $\begin{array}{c}23.934 * * * \\
(5.144)\end{array}$ & $\begin{array}{c}0.358 * * \\
(0.144)\end{array}$ & $\begin{array}{c}-2.361 * * * \\
(0.485)\end{array}$ & $\begin{array}{c}-1.252 * * * \\
(0.237)\end{array}$ & $\begin{array}{c}0.335 \\
(0.368)\end{array}$ & $\begin{array}{c}18.573 * * * \\
(5.673)\end{array}$ & $\begin{array}{c}0.294 * * \\
(0.147)\end{array}$ & $\begin{array}{c}-2.173 * * * \\
(0.442)\end{array}$ & $\begin{array}{c}-1.037 * * * \\
(0.218)\end{array}$ & $\begin{array}{c}0.045 \\
(0.115)\end{array}$ \\
\hline Loan Characteristics & YES & YES & YES & YES & YES & YES & YES & YES & YES & YES \\
\hline Borrower Characteristics & YES & YES & YES & YES & YES & YES & YES & YES & YES & YES \\
\hline Borrower Fixed Effects & NO & NO & NO & NO & NO & YES & YES & YES & YES & YES \\
\hline Year Fixed Effects & YES & YES & YES & YES & YES & YES & YES & YES & YES & YES \\
\hline Industry Fixed Effects & YES & YES & YES & YES & YES & YES & YES & YES & YES & YES \\
\hline Rating Fixed Effects & YES & YES & YES & YES & YES & YES & YES & YES & YES & YES \\
\hline Loan Type Fixed Effects & YES & YES & YES & YES & YES & YES & YES & YES & YES & YES \\
\hline Loan Purpose Fixed Effects & YES & YES & YES & YES & YES & YES & YES & YES & YES & YES \\
\hline Number of Observations & 1517 & 1463 & 1189 & 1189 & 428 & 1517 & 1463 & 1189 & 1189 & 428 \\
\hline $\mathrm{R}^{2}$ & 0.664 & 0.144 & 0.269 & 0.208 & 0.245 & 0.929 & 0.645 & 0.831 & 0.789 & 0.817 \\
\hline
\end{tabular}




\section{Table V}

\section{Dynamic Loan Contracting Following Covenant Violations in the Prior Loan - Alternative Explanations - Credit Risk - Matching and Regression Discontinuity}

The table reports results from a propensity score matching model (Panel A) and multivariate regressions (Panel B) of various price and non-price loan contract terms. These are the (1) All-in-Spread-Drawn, (2) the number of financial covenants, (3) the average distance to covenant violation (DCV), (4) the DCV, and (5) the contract intensity. Prior covenant violation is a dummy variable equal to one if the borrower violated a financial covenant in the prior loan contract. Panel A shows results from propensity score matching using a nearest neighbor estimator with 10, 50 and 100 nearest neighbors together with a Gaussian and an Epanechnikov kernel estimator with a bandwidth of 0.01 . The propensity score is calculated using a probit regression of covenant violation on all control variables from Table III in addition to changes in the borrower characteristics variables in Table III, the change in facility size, and the change in borrower rating from the time of covenant violation until the initiation of the subsequent new contract. If there is no covenant violation, the same variables' changes are calculated from the contract end date of the unviolated contract until the initiation of the subsequent new contract. In parentheses bootstrapped standard errors are reported using 50 replications. Panel B reports the results from a regression discontinuity analysis. It only includes these new loans where in the prior contract the distance of at least one covenant to its respective covenant threshold is at maximum 1 standard deviation in the year prior to the new loan contract, that is, the distance to covenant violation is in the interval $(-1 ; 1)$ in the year before the new contract is initiated. All variables are described in Appendix 1. In Model (5) "Secured" is excluded as it is part of the dependent variable. Standard errors shown in parentheses are robust to heteroscedasticity and clustered at the firm level. The statistical significance of results is indicated by $*=10 \%$ level, $* *=5 \%$ level and $* * *=1 \%$ level.

\begin{tabular}{|c|c|c|c|c|c|}
\hline Panel A. Propensity Score Matching & (1) & $(2)$ & (3) & 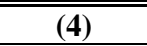 & (5) \\
\hline & AISD & $\begin{array}{l}\text { Covenant } \\
\text { Number }\end{array}$ & Average DCV & DCV & $\begin{array}{l}\text { Contract } \\
\text { Intensity }\end{array}$ \\
\hline $\begin{array}{l}\text { Prior Covenant Violation } \\
(\text { Nearest Neighbor }(n=10))\end{array}$ & $\begin{array}{c}37.014 * * \\
(14.437)\end{array}$ & $\begin{array}{c}0.316 * * * \\
(0.115)\end{array}$ & $\begin{array}{c}-0.708 * * \\
(0.323)\end{array}$ & $\begin{array}{l}-0.450^{*} \\
(0.269)\end{array}$ & $\begin{array}{c}0.405 \\
(0.296)\end{array}$ \\
\hline $\begin{array}{l}\text { Prior Covenant Violation } \\
(\text { Nearest Neighbor }(n=50))\end{array}$ & $\begin{array}{l}46.272 * * * \\
(9.149)\end{array}$ & $\begin{array}{c}0.298 * * * \\
(0.089)\end{array}$ & $\begin{array}{c}-0.843 * * * \\
(0.265)\end{array}$ & $\begin{array}{c}-0.539 * * * \\
(0.186)\end{array}$ & $\begin{array}{c}0.401 * * \\
(0.173)\end{array}$ \\
\hline $\begin{array}{l}\text { Prior Covenant Violation } \\
\text { (Nearest Neighbor }(\mathrm{n}=100))\end{array}$ & $\begin{array}{l}54.658 * * * \\
(8.832)\end{array}$ & $\begin{array}{c}0.189 * * \\
(0.076)\end{array}$ & $\begin{array}{l}-1.001 * * * \\
(0.245)\end{array}$ & $\begin{array}{c}-0.684 * * * \\
(0.251)\end{array}$ & $\begin{array}{c}0.407 * * \\
(0.201)\end{array}$ \\
\hline $\begin{array}{l}\text { Prior Covenant Violation } \\
\text { (Gaussian) }\end{array}$ & $\begin{array}{c}24.624 * * * \\
(10.173)\end{array}$ & $\begin{array}{c}0.315 * * \\
(0.133)\end{array}$ & $\begin{array}{c}-0.703 * * \\
(0.322)\end{array}$ & $\begin{array}{l}-0.507 * \\
(0.271)\end{array}$ & $\begin{array}{l}0.408^{*} \\
(0.246)\end{array}$ \\
\hline $\begin{array}{l}\text { Prior Covenant Violation } \\
\text { (Epanechnikov) }\end{array}$ & $\begin{array}{c}43.983 * * * \\
(13.582)\end{array}$ & $\begin{array}{c}0.356 * * \\
(0.153)\end{array}$ & $\begin{array}{c}-1.038 * * * \\
(0.363)\end{array}$ & $\begin{array}{c}-1.077 * * * \\
(0.350)\end{array}$ & $\begin{array}{c}0.432 \\
(0.355) \\
\end{array}$ \\
\hline
\end{tabular}

\begin{tabular}{|c|c|c|c|c|c|}
\hline Panel B. Regression Discontinuity & $\overline{(1)}$ & (2) & (3) & (4) & 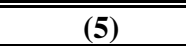 \\
\hline Dependent Variable & AISD & $\begin{array}{l}\text { Covenant } \\
\text { Number }\end{array}$ & Average DCV & DCV & $\begin{array}{l}\text { Contract } \\
\text { Intensity }\end{array}$ \\
\hline Regression Methodology & OLS & Ordered Logit & OLS & OLS & Ordered Logit \\
\hline Prior Covenant Violation & $\begin{array}{c}21.278 * * \\
(9.973)\end{array}$ & $\begin{array}{c}0.186 \\
(0.258)\end{array}$ & $\begin{array}{c}-0.556 * * \\
(0.243)\end{array}$ & $\begin{array}{c}-0.251^{* *} \\
(0.127)\end{array}$ & $\begin{array}{c}\text { Insufficient } \\
\text { Observations }\end{array}$ \\
\hline Loan Characteristics & YES & YES & YES & YES & YES \\
\hline Borrower Characteristics & YES & YES & YES & YES & YES \\
\hline Year Fixed Effects & YES & YES & YES & YES & YES \\
\hline Industry Fixed Effects & YES & YES & YES & YES & YES \\
\hline Rating Fixed Effects & YES & YES & YES & YES & YES \\
\hline Loan Type Fixed Effects & YES & YES & YES & YES & YES \\
\hline Loan Purpose Fixed Effects & YES & YES & YES & YES & YES \\
\hline Number of Observations & 726 & 715 & 592 & 592 & \\
\hline $\mathrm{R}^{2}$ & 0.545 & 0.164 & 0.203 & 0.213 & \\
\hline
\end{tabular}




\section{Table VI}

\section{Dynamic Loan Contracting Following Covenant Violations in the Prior Loan - Alternative Explanations - Managerial Agency Problems}

The table reports descriptive statistics of changes in CEO data (Panel A) as well as results from multivariate regressions of different dependent variables (Panel B). The latter are the All-in-Spread-Drawn, the number of financial covenants, the average distance to covenant violation (DCV) and the DCV. Results for the contract intensity are not reported due to insufficient observations. Prior covenant violation is a dummy variable equal to one if the borrower violated a financial covenant in the prior loan contract. The change in CEO data is derived from ExecuComp and amended with the reason why the CEO left the firm from Eisfeldt and Kuhnen (2013) available at Andrea L. Eisfeldt's personal website for the period 1992 to 2006 . Panel A shows the number and percentage of changes in CEO by the reason why the CEO left the firm using only the classifications from ExecuComp over 1996 to 2010 in column (1), using only the classifications from Eisfeldt and Kuhnen (2013) over 1996 to 2006 in column (2), and using the classifications from Eisfeldt and Kuhnen (2013) over 1996 to 2006 and the classifications from ExecuComp from 2007 to 2010 in column (3). All regressions in panel B include variables defined as in Panel A column (3) and the control variables from Table III described in Appendix 1. Standard errors shown in parentheses are robust to heteroscedasticity and clustered at the firm level. The statistical significance of results is indicated by $*$ $=10 \%$ level, $* *=5 \%$ level and $* * *=1 \%$ level.

\begin{tabular}{lccc}
\hline \hline Panel A & $\mathbf{( 1 )}$ & $\mathbf{( 2 )}$ & $\mathbf{( 3 )}$ \\
\hline Data Source & $\begin{array}{c}\text { Only } \\
\text { ExecuComp }\end{array}$ & $\begin{array}{c}\text { Only } \\
\text { Eisfeldt and Kuhnen (2013) }\end{array}$ & $\begin{array}{c}\text { Eisfeldt and Kuhnen (2013) } \\
\text { and ExecuComp }\end{array}$ \\
\hline Resigned / Forced Turnover & 99 & 61 & 93 \\
& $18.929 \%$ & $15.762 \%$ & $17.782 \%$ \\
Retired & 179 & 111 & 157 \\
& $34.226 \%$ & $28.682 \%$ & $30.019 \%$ \\
Unknown /Unclassified & 245 & 215 & 273 \\
Turnover & $46.845 \%$ & $55.556 \%$ & $52.199 \%$ \\
Total Number of CEO & 523 & 387 & 523 \\
Changes & & & 5 \\
\hline \hline
\end{tabular}

\begin{tabular}{|c|c|c|c|c|}
\hline Panel B & $(\mathbf{1})$ & $\begin{array}{l}(2) \\
\end{array}$ & 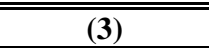 & $\overline{(4)}$ \\
\hline Dependent Variable & AISD & $\begin{array}{l}\text { Covenant } \\
\text { Number }\end{array}$ & Average DCV & DCV \\
\hline Regression Methodology & OLS & Ordered Logit & OLS & OLS \\
\hline Prior Covenant Violation & $\begin{array}{c}17.199 * * * \\
(5.139)\end{array}$ & $\begin{array}{c}0.386 * * * \\
(0.150)\end{array}$ & $\begin{array}{c}-1.346^{* * *} * \\
(0.486)\end{array}$ & $\begin{array}{c}-1.202 * * * \\
(0.331)\end{array}$ \\
\hline Change in CEO - Resigned & $\begin{array}{l}30.450 * * \\
(12.210)\end{array}$ & $\begin{array}{l}-0.185 \\
(0.351)\end{array}$ & $\begin{array}{c}1.329 \\
(1.546)\end{array}$ & $\begin{array}{c}0.250 \\
(1.220)\end{array}$ \\
\hline Change in CEO - Retired & $\begin{array}{c}1.599 \\
(8.563)\end{array}$ & $\begin{array}{c}0.384 \\
(0.270)\end{array}$ & $\begin{array}{c}0.424 \\
(0.811)\end{array}$ & $\begin{array}{l}-0.515 \\
(0.657)\end{array}$ \\
\hline Change in CEO - Unknown & $\begin{array}{l}-1.042 \\
(6.885)\end{array}$ & $\begin{array}{l}-0.165 \\
(0.231)\end{array}$ & $\begin{array}{c}1.144 \\
(1.006)\end{array}$ & $\begin{array}{c}0.657 \\
(0.850)\end{array}$ \\
\hline $\begin{array}{l}\text { Prior Covenant Violation } * \\
\text { Change in CEO - Resigned }\end{array}$ & $\begin{array}{l}-28.662 \\
(19.025)\end{array}$ & $\begin{array}{l}-0.330 \\
(0.639)\end{array}$ & $\begin{array}{l}-3.558 * \\
(2.100)\end{array}$ & $\begin{array}{l}-2.085 \\
(1.416)\end{array}$ \\
\hline Prior Covenant Violation * & -5.805 & -0.415 & 1.292 & 1.094 \\
\hline Change in CEO - Retired & $(15.344)$ & $(0.454)$ & $(1.349)$ & $(0.875)$ \\
\hline Prior Covenant Violation * & -9.709 & 0.176 & -0.827 & -0.332 \\
\hline Change in CEO - Unknown & $(10.252)$ & $(0.339)$ & $(1.179)$ & $(0.940)$ \\
\hline Control Variables & YES & YES & YES & YES \\
\hline $\begin{array}{l}\text { Number of Observations } \\
\mathrm{R}^{2}\end{array}$ & $\begin{array}{l}1,948 \\
0.711 \\
\end{array}$ & $\begin{array}{l}1,904 \\
0.189 \\
\end{array}$ & $\begin{array}{l}1,612 \\
0.238 \\
\end{array}$ & $\begin{array}{l}1,612 \\
0.185 \\
\end{array}$ \\
\hline
\end{tabular}




\section{Table VII}

\section{Dynamic Loan Contracting Following Covenant Violations in the Prior Loan - Alternative Explanations - Debt Capital Market Access and Institutional Ownership}

The table reports results from multivariate regressions of various price and non-price loan contract terms on prior covenant violation and control variables. These are the (1) All-in-Spread-Drawn, (2) the number of financial covenants, (3) the average distance to covenant violation (DCV), (4) the DCV, and (5) the contract intensity. Prior covenant violation is a dummy variable equal to one if the borrower violated a financial covenant in the prior loan contract. In Panel A, Debt Capital Market Access is a dummy variable if the firm issued a bond or a note with a notional of at least $\$ 10$ million between the prior and the new loan. The regressions in Panel A include data from 2001 to 2010 because the latter variable is derived using Capital IQ where information on firm debt is included only from 2001 on. In Panel B, Institutional Ownership (\%) indicates the percentage of institutional owners of the firm at the initiation of the new loan derived from 13f filings. All variables are described in Appendix 1. In Model (5) "Secured" is excluded as it is part of the dependent variable. Standard errors shown in parentheses are robust to heteroscedasticity and clustered at the firm level. The statistical significance of results is indicated by $*=10 \%$ level, $* *=5 \%$ level and $* * *=1 \%$ level.

\begin{tabular}{|c|c|c|c|c|c|}
\hline "Panel A: DCM Access & (1) & (2) & 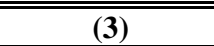 & (4) & 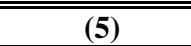 \\
\hline Dependent Variable & AISD & $\begin{array}{l}\text { Covenant } \\
\text { Number }\end{array}$ & Average DCV & DCV & $\begin{array}{l}\text { Contract } \\
\text { Intensity }\end{array}$ \\
\hline Regression Methodology & OLS & Ordered Logit & OLS & OLS & Ordered Logit \\
\hline Prior Covenant Violation & $\begin{array}{c}22.217 * * * \\
(6.903)\end{array}$ & $\begin{array}{c}0.114 \\
(0.172)\end{array}$ & $\begin{array}{c}-1.705 * * \\
(0.700)\end{array}$ & $\begin{array}{l}-0.846^{*} \\
(0.447)\end{array}$ & $\begin{array}{c}0.242 \\
(0.485)\end{array}$ \\
\hline Debt Capital Market Access & $\begin{array}{l}-4.733 \\
(5.930)\end{array}$ & $\begin{array}{l}-0.150 \\
(0.154)\end{array}$ & $\begin{array}{l}-0.382 \\
(0.570)\end{array}$ & $\begin{array}{c}0.281 \\
(0.418)\end{array}$ & $\begin{array}{l}-0.084 \\
(0.566)\end{array}$ \\
\hline $\begin{array}{l}\text { Prior Covenant Violation * } \\
\text { Capital Market Access }\end{array}$ & $\begin{array}{l}-9.291 \\
(8.321)\end{array}$ & $\begin{array}{l}0.440 * * \\
(0.218)\end{array}$ & $\begin{array}{c}0.504 \\
(0.708)\end{array}$ & $\begin{array}{l}-0.309 \\
(0.525)\end{array}$ & $\begin{array}{c}0.242 \\
(0.644)\end{array}$ \\
\hline Loan Characteristics & YES & YES & YES & YES & YES \\
\hline Borrower Characteristics & YES & YES & YES & YES & YES \\
\hline Year Fixed Effects & YES & YES & YES & YES & YES \\
\hline Industry Fixed Effects & YES & YES & YES & YES & YES \\
\hline Rating Fixed Effects & YES & YES & YES & YES & YES \\
\hline Loan Type Fixed Effects & YES & YES & YES & YES & YES \\
\hline Loan Purpose Fixed Effects & YES & YES & YES & YES & YES \\
\hline Number of Observations & 2,305 & 2,236 & 1,888 & 1,888 & 574 \\
\hline $\mathrm{R}^{2}$ & 0.679 & 0.166 & 0.247 & 0.177 & 0.184 \\
\hline Panel B: Institutional Ownership & $(\mathbf{1})$ & $(2)$ & $(3)$ & $(4)$ & $(5)$ \\
\hline Dependent Variable & AISD & $\begin{array}{l}\text { Covenant } \\
\text { Number }\end{array}$ & Average DCV & DCV & $\begin{array}{l}\text { Contract } \\
\text { Intensity }\end{array}$ \\
\hline Regression Methodology & OLS & Ordered Logit & OLS & OLS & Ordered Logit \\
\hline Prior Covenant Violation & $\begin{array}{c}25.074 * * * \\
(4.588)\end{array}$ & $\begin{array}{c}0.353 * * * \\
(0.133)\end{array}$ & $\begin{array}{c}-1.743 * * * \\
(0.434)\end{array}$ & $\begin{array}{c}-1.166^{* * * *} \\
(0.275)\end{array}$ & $\begin{array}{l}0.499 * \\
(0.289)\end{array}$ \\
\hline Institutional Ownership (\%) & $\begin{array}{l}3.409 \\
(7.537)\end{array}$ & $\begin{array}{l}-0.265 \\
(0.210)\end{array}$ & $\begin{array}{l}-0.726 \\
(0.635)\end{array}$ & $\begin{array}{l}-0.573 \\
(0.583)\end{array}$ & $\begin{array}{c}0.105 \\
(0.568)\end{array}$ \\
\hline $\begin{array}{l}\text { Prior Covenant Violation * } \\
\text { Institutional Ownership }(\%)\end{array}$ & $\begin{array}{c}-30.090 * * * \\
(9.921)\end{array}$ & $\begin{array}{c}0.269 \\
(0.269)\end{array}$ & $\begin{array}{c}0.916 \\
(0.758)\end{array}$ & $\begin{array}{c}0.476 \\
(0.621)\end{array}$ & $\begin{array}{l}-0.256 \\
(0.684)\end{array}$ \\
\hline Loan Characteristics & YES & YES & YES & YES & YES \\
\hline Borrower Characteristics & YES & YES & YES & YES & YES \\
\hline Year Fixed Effects & YES & YES & YES & YES & YES \\
\hline Industry Fixed Effects & YES & YES & YES & YES & YES \\
\hline Rating Fixed Effects & YES & YES & YES & YES & YES \\
\hline Loan Type Fixed Effects & YES & YES & YES & YES & YES \\
\hline Loan Purpose Fixed Effects & YES & YES & YES & YES & YES \\
\hline Number of Observations & 2,786 & 2,709 & 2,272 & 2,272 & 848 \\
\hline $\mathrm{R}^{2}$ & 0.667 & 0.165 & 0.222 & 0.180 & 0.188 \\
\hline
\end{tabular}




\section{Table VIII \\ Dynamic Loan Contracting Following Covenant Violations in the Prior Loan - Violation Severity}

The table reports results from multivariate regressions of various price and non-price loan contract terms on prior covenant violation and control variables. These are the (1) All-in-Spread-Drawn, (2) the number of financial covenants, (3) the average distance to covenant violation (DCV), (4) the DCV, and (5) the contract intensity. "X Covenant(s) Violated" is the number of covenants violated in the prior loan contract. All variables are described in Appendix 1. In Model (5) "Secured" is excluded as it is part of the dependent variable. Standard errors shown in parentheses are robust to heteroscedasticity and clustered at the firm level. The statistical significance of results is indicated by $*=10 \%$ level, $* *=5 \%$ level and $* * *=1 \%$ level.

\begin{tabular}{|c|c|c|c|c|c|}
\hline & (1) & (2) & (3) & (4) & (5) \\
\hline Dependent Variable & AISD & $\begin{array}{l}\text { Covenant } \\
\text { Number }\end{array}$ & Average DCV & DCV & $\begin{array}{l}\text { Contract } \\
\text { Intensity }\end{array}$ \\
\hline Regression Methodology & OLS & Ordered Logit & OLS & OLS & Ordered Logit \\
\hline \multicolumn{6}{|l|}{ Prior Covenant Violation } \\
\hline 1 Covenant Violated & $\begin{array}{c}5.284 \\
(4.793)\end{array}$ & $\begin{array}{c}0.188 \\
(0.129)\end{array}$ & $\begin{array}{c}-1.432 * * * \\
(0.384)\end{array}$ & $\begin{array}{c}-1.039 * * * \\
(0.268)\end{array}$ & $\begin{array}{c}0.285 \\
(0.292)\end{array}$ \\
\hline 2 Covenants Violated & $\begin{array}{c}22.867 * * * \\
(5.783)\end{array}$ & $\begin{array}{c}0.358 * * \\
(0.160)\end{array}$ & $\begin{array}{c}-1.433 * * * \\
(0.409)\end{array}$ & $\begin{array}{c}-1.124 * * * \\
(0.215)\end{array}$ & $\begin{array}{c}0.433 \\
(0.293)\end{array}$ \\
\hline 3 Covenants Violated & $\begin{array}{c}31.537 * * * \\
(7.385)\end{array}$ & $\begin{array}{c}0.849 * * * \\
(0.219)\end{array}$ & $\begin{array}{c}-1.918^{* * * *} \\
(0.410)\end{array}$ & $\begin{array}{c}-0.895 * * * \\
(0.232)\end{array}$ & $\begin{array}{c}0.907 * * * \\
(0.329)\end{array}$ \\
\hline 4 or more Covenants Violated & $\begin{array}{c}51.608 * * * \\
(10.965)\end{array}$ & $\begin{array}{c}1.920 * * * \\
(0.324)\end{array}$ & $\begin{array}{c}-2.078 * * * \\
(0.463)\end{array}$ & $\begin{array}{c}-1.409 * * * \\
(0.286)\end{array}$ & $\begin{array}{c}0.464 \\
(0.630)\end{array}$ \\
\hline Loan Characteristics & YES & YES & YES & YES & YES \\
\hline Borrower Characteristics & YES & YES & YES & YES & YES \\
\hline Year Fixed Effects & YES & YES & YES & YES & YES \\
\hline Industry Fixed Effects & YES & YES & YES & YES & YES \\
\hline Rating Fixed Effects & YES & YES & YES & YES & YES \\
\hline Loan Type Fixed Effects & YES & YES & YES & YES & YES \\
\hline Loan Purpose Fixed Effects & YES & YES & YES & YES & YES \\
\hline Number of Observations & 2,786 & 2,709 & 2,272 & 2,272 & 848 \\
\hline $\mathrm{R}^{2}$ & 0.671 & 0.177 & 0.223 & 0.18 & 0.192 \\
\hline
\end{tabular}




\section{Table IX}

\section{Dynamic Loan Contracting Following Covenant Violations in the Prior Loan - Type of Covenant Violation and Type of Covenant included}

The table reports in Panel B descriptive results and in Panel A and C results from multivariate regressions of various price and non-price loan contract terms on the type of prior covenant violation and control variables. These are the (1) All-in-Spread-Drawn, (2) the number of financial covenants, (3) the average distance to covenant violation (DCV), (4) the DCV, and (5) the contract intensity. Each type of prior covenant violation is indicated by a dummy variable equal to one if the borrower violated at least one covenant of this financial covenant type in the prior loan contract. Profitability-based and capital-based covenants are defined following Christensen and Nikolaev (2012). Violation Profitability Covenant indicates violations of EBITDA, Debt to EBITDA, Debt Service Coverage Ratio, Fixed Charge Coverage Ratio, Interest Coverage Ratio or Senior Debt to EBITDA covenants in the prior loan; Violation Capital Covenant includes violations of Asset Coverage Ratio, Current Ratio, Debt to Capitalization, Debt to Net Worth, Net Worth, Quick Ratio, Senior Debt to Capitalization, Senior Debt to Net Worth, Tangible Net Worth, Working Capital covenants; Violation Leverage Covenant includes Debt to Capitalization and Senior Debt to Capitalization covenants; Violation Net Worth Covenant includes Debt to Net Worth, Net Worth, Senior Debt to Net Worth and Tangible Net Worth covenants; Violation Short-term Covenant includes Asset Coverage Ratio, Current Ratio, Quick Ratio, Working Capital, Cash and Cash Equivalents covenants. Note that Cash and Cash Equivalents are neither classified as profitability nor as capital covenants in Christensen and Nikolaev (2012), but are included in our classification of Short-term Covenants. All variables are described in Appendix 1. In Model (5) in Panel A "Secured" is excluded as it is part of the dependent variable. Panel B shows the percentage of contracts including a (1) Profitability covenant, (2) Capital Covenant, (3) Leverage Covenant, (4) Net Worth Covenant and (5) Short-term Covenant given that the covenant type mentioned in the first column was violated in the prior loan. Standard errors shown in parentheses are robust to heteroscedasticity and clustered at the firm level. The statistical significance of results is indicated by $*=10 \%$ level, $* *=5 \%$ level and $* * *=1 \%$ level.

\begin{tabular}{|c|c|c|c|c|c|}
\hline Panel A: Violated Covenant Type & $(\mathbf{1})$ & $(2)$ & (3) & $(4)$ & $(5)$ \\
\hline Dependent Variable & AISD & $\begin{array}{c}\text { Covenant } \\
\text { Number }\end{array}$ & Average DCV & DCV & $\begin{array}{l}\text { Contract } \\
\text { Intensity }\end{array}$ \\
\hline Regression Methodology & OLS & Ordered Logit & OLS & OLS & Ordered Logit \\
\hline \multicolumn{6}{|l|}{ Prior Covenant Violation } \\
\hline Violation Profitability Covenant & $\begin{array}{c}15.753 * * * \\
(4.190)\end{array}$ & $\begin{array}{c}0.350 * * * \\
(0.121)\end{array}$ & $\begin{array}{c}-1.270 * * * \\
(0.393)\end{array}$ & $\begin{array}{c}-0.651 * * * \\
(0.206)\end{array}$ & $\begin{array}{c}0.531 * * \\
(0.240)\end{array}$ \\
\hline Violation Capital Covenant & $\begin{array}{c}19.077 * * * \\
(5.330)\end{array}$ & $\begin{array}{c}0.397 * * * \\
(0.147)\end{array}$ & $\begin{array}{c}-1.035 * * * \\
(0.265)\end{array}$ & $\begin{array}{c}-0.680^{* * *} \\
(0.165)\end{array}$ & $\begin{array}{c}0.167 \\
(0.267)\end{array}$ \\
\hline Loan Characteristics & YES & YES & YES & YES & YES \\
\hline Borrower Characteristics & YES & YES & YES & YES & YES \\
\hline Year Fixed Effects & YES & YES & YES & YES & YES \\
\hline Industry Fixed Effects & YES & YES & YES & YES & YES \\
\hline Rating Fixed Effects & YES & YES & YES & YES & YES \\
\hline Loan Type Fixed Effects & YES & YES & YES & YES & YES \\
\hline Loan Purpose Fixed Effects & YES & YES & YES & YES & YES \\
\hline Number of Observations & 2,786 & 2,709 & 2,272 & 2,272 & 848 \\
\hline $\mathrm{R}^{2}$ & 0.667 & 0.167 & 0.224 & 0.178 & 0.189 \\
\hline
\end{tabular}




\section{Table IX continued}

\section{Dynamic Loan Contracting Following Covenant Violations in the Prior Loan - Type of Covenant Violation and Type of Covenant included}

\begin{tabular}{|c|c|c|c|c|c|}
\hline $\begin{array}{l}\text { Panel B: Percentage of Contracts } \\
\text { Including a Covenant Type } \\
\text { conditional on having violated a } \\
\text { Specific Covenant Type in the } \\
\text { Prior Contract }\end{array}$ & (1) & (2) & (3) & (4) & (5) \\
\hline & $\begin{array}{c}\text { Profitability } \\
\text { Covenant }\end{array}$ & $\begin{array}{c}\text { Capital } \\
\text { Covenant }\end{array}$ & $\begin{array}{l}\text { Leverage } \\
\text { Covenant }\end{array}$ & $\begin{array}{l}\text { Net Worth } \\
\text { Covenant }\end{array}$ & $\begin{array}{c}\text { Short-term } \\
\text { Covenant }\end{array}$ \\
\hline $\begin{array}{l}\text { Prior Covenant Violation } \\
\text { Violation Profitability Covenant }\end{array}$ & $96.49 \%$ & $40.62 \%$ & $7.58 \%$ & $29.57 \%$ & $48.31 \%$ \\
\hline $\begin{array}{l}\text { Violation Capital Covenant } \\
\text { Violation Leverage Covenant } \\
\text { Violation Net Worth Covenant } \\
\text { Violation Short-term Covenant } \\
\end{array}$ & $\begin{array}{l}89.86 \% \\
80.39 \% \\
92.39 \% \\
91.56 \% \\
\end{array}$ & $\begin{array}{l}68.28 \% \\
71.08 \% \\
63.04 \% \\
77.92 \% \\
\end{array}$ & $\begin{array}{l}23.46 \% \\
55.14 \% \\
13.28 \% \\
16.56 \% \\
\end{array}$ & $\begin{array}{l}40.90 \% \\
26.17 \% \\
53.39 \% \\
31.29 \% \\
\end{array}$ & $\begin{array}{l}48.15 \% \\
46.26 \% \\
39.84 \% \\
65.64 \% \\
\end{array}$ \\
\hline \multirow[t]{2}{*}{$\begin{array}{l}\text { Panel C: Included Covenant Type } \\
\text { by violated Covenant Type }\end{array}$} & (1) & (2) & (3) & (4) & (5) \\
\hline & $\begin{array}{l}\text { Profitability } \\
\text { Covenant }\end{array}$ & $\begin{array}{c}\text { Capital } \\
\text { Covenant }\end{array}$ & $\begin{array}{c}\text { Capital } \\
\text { Covenant }\end{array}$ & $\begin{array}{c}\text { Percentage of } \\
\text { Profitability } \\
\text { Covenants } \\
\end{array}$ & $\begin{array}{c}\text { Percentage of } \\
\text { Profitability } \\
\text { Covenants } \\
\end{array}$ \\
\hline Regression Methodology & Logit & Logit & Logit & OLS & OLS \\
\hline Violation Profitability Covenant & $\begin{array}{c}1.194 * * * \\
(0.272)\end{array}$ & $\begin{array}{c}-0.638 * * * \\
(0.149)\end{array}$ & $\begin{array}{l}-0.612 * * * \\
(0.149)\end{array}$ & $\begin{array}{l}0.107 * * * \\
(0.018)\end{array}$ & $\begin{array}{c}0.107 * * * \\
(0.018)\end{array}$ \\
\hline Violation Capital Covenant & $\begin{array}{l}-0.203 \\
(0.280)\end{array}$ & $\begin{array}{c}1.170 * * * \\
(0.175)\end{array}$ & & $\begin{array}{l}-0.084 * * * \\
(0.019)\end{array}$ & \\
\hline Violation Leverage Covenant & & & $\begin{array}{c}1.081 * * * \\
(0.332)\end{array}$ & & $\begin{array}{c}-0.082 * * \\
(0.036)\end{array}$ \\
\hline Violation Net Worth Covenant & & & $\begin{array}{c}0.890^{* * * *} \\
(0.204)\end{array}$ & & $\begin{array}{l}-0.070 * * * \\
(0.022)\end{array}$ \\
\hline Violation Short-term Covenant & & & $\begin{array}{l}0.795^{*} \\
(0.412)\end{array}$ & & $\begin{array}{c}-0.072 * * \\
(0.035)\end{array}$ \\
\hline Loan Characteristics & YES & YES & YES & YES & YES \\
\hline Borrower Characteristics & YES & YES & YES & YES & YES \\
\hline Year Fixed Effects & YES & YES & YES & YES & YES \\
\hline Industry Fixed Effects & YES & YES & YES & YES & YES \\
\hline Rating Fixed Effects & YES & YES & YES & YES & YES \\
\hline Loan Type Fixed Effects & YES & YES & YES & YES & YES \\
\hline Loan Purpose Fixed Effects & YES & YES & YES & YES & YES \\
\hline Number of Observations & 2497 & 2497 & 2497 & 2693 & 2693 \\
\hline $\mathrm{R}^{2}$ & 0.365 & 0.236 & 0.232 & 0.343 & 0.344 \\
\hline
\end{tabular}




\section{Table X}

\section{The Dynamic Effect of Past Covenant Violations on Loan Contract Terms}

The table reports results from multivariate regressions of various price and non-price loan contract terms on covenant violations and control variables. These are the (1) All-in-Spread-Drawn, (2) the number of financial covenants, (3) the average distance to covenant violation (DCV), (4) the DCV, and (5) the contract intensity as well as in Panel $\mathrm{C}$ the percentage of profitability covenants. The regressions segregate the sample into different time periods reflecting the sequence of loans of individual borrowers. Second (Third) Loan is an indicator variable for the second (third) loan, the first loan is the base case. "Second Loan, Violation in First Loan" (Third Loan, Violation in Second Loan) is an indicator variable equal to 1 if the borrower has violated a covenant in the first (second) loan and obtains the second (third) loan. All variables are described in Appendix 1. In Models (5) and (10) "Secured" is excluded as it is part of the dependent variable. Standard errors shown in parentheses are robust to heteroscedasticity and clustered at the firm level. The statistical significance of results is indicated by $*=10 \%$ level, $* *=5 \%$ level and $* * *$ $=1 \%$ level.

\begin{tabular}{|c|c|c|c|c|c|c|c|c|c|c|}
\hline Panel A & $(\mathbf{( 1 )}$ & (2) & (3) & (4) & (5) & (6) & (7) & (8) & (9) & (10) \\
\hline Dependent Variable & AISD & $\begin{array}{l}\text { Covenant } \\
\text { Number }\end{array}$ & $\begin{array}{c}\text { Average } \\
\text { DCV }\end{array}$ & DCV & $\begin{array}{l}\text { Contract } \\
\text { Intensity }\end{array}$ & AISD & $\begin{array}{c}\text { Covenant } \\
\text { Number }\end{array}$ & $\begin{array}{c}\text { Average } \\
\text { DCV }\end{array}$ & DCV & $\begin{array}{l}\text { Contract } \\
\text { Intensity }\end{array}$ \\
\hline Regression Methodology & OLS & $\begin{array}{c}\text { Ordered } \\
\text { Logit }\end{array}$ & OLS & OLS & $\begin{array}{c}\text { Ordered } \\
\text { Logit }\end{array}$ & OLS & $\begin{array}{c}\text { Ordered } \\
\text { Logit }\end{array}$ & OLS & OLS & $\begin{array}{c}\text { Ordered } \\
\text { Logit }\end{array}$ \\
\hline Second Loan & $\begin{array}{l}-6.435 \\
(4.118)\end{array}$ & $\begin{array}{c}-0.199 * \\
(0.114)\end{array}$ & $\begin{array}{c}1.704 * * * \\
(0.449)\end{array}$ & $\begin{array}{c}0.957 * * \\
(0.377)\end{array}$ & $\begin{array}{c}0.081 \\
(0.264)\end{array}$ & $\begin{array}{l}-5.973 \\
(3.980)\end{array}$ & $\begin{array}{l}-0.202 \\
(0.123)\end{array}$ & $\begin{array}{c}1.963 * * * \\
(0.440)\end{array}$ & $\begin{array}{c}1.121 * * * \\
(0.360)\end{array}$ & $\begin{array}{c}0.003 \\
(0.183)\end{array}$ \\
\hline Second Loan, Violation in First Loan & $\begin{array}{c}17.259 * * * \\
(5.069)\end{array}$ & $\begin{array}{c}0.352 * * \\
(0.139)\end{array}$ & $\begin{array}{c}-1.780 * * * \\
(0.440)\end{array}$ & $\begin{array}{c}-1.110 * * * \\
(0.354)\end{array}$ & $\begin{array}{c}0.138 \\
(0.298)\end{array}$ & $\begin{array}{c}13.720 * * * \\
(4.420)\end{array}$ & $\begin{array}{c}0.153 * * \\
(0.063)\end{array}$ & $\begin{array}{c}-1.961 * * * \\
(0.421)\end{array}$ & $\begin{array}{c}-1.321 * * * \\
(0.369)\end{array}$ & $\begin{array}{l}-0.380 \\
(0.239)\end{array}$ \\
\hline Third Loan & $\begin{array}{l}-7.888 \\
(5.739)\end{array}$ & $\begin{array}{l}-0.153 \\
(0.134)\end{array}$ & $\begin{array}{c}2.304 * * * \\
(0.637)\end{array}$ & $\begin{array}{c}1.592 * * * \\
(0.503)\end{array}$ & $\begin{array}{l}-0.052 \\
(0.347)\end{array}$ & $\begin{array}{l}-8.219 \\
(5.162)\end{array}$ & $\begin{array}{l}-0.085 \\
(0.102)\end{array}$ & $\begin{array}{c}2.336 * * * \\
(0.704)\end{array}$ & $\begin{array}{c}1.732 * * * \\
(0.588)\end{array}$ & $\begin{array}{l}-0.035 \\
(0.295)\end{array}$ \\
\hline Third Loan, Violation in Second Loan & $\begin{array}{l}12.213^{*} \\
(6.761)\end{array}$ & $\begin{array}{c}0.348 * * \\
(0.161)\end{array}$ & $\begin{array}{c}-2.402 * * * \\
(0.644)\end{array}$ & $\begin{array}{c}-1.677 * * * \\
(0.454)\end{array}$ & $\begin{array}{c}0.279 \\
(0.380)\end{array}$ & $\begin{array}{c}10.874 * \\
(5.756)\end{array}$ & $\begin{array}{c}0.147 * * \\
(0.064)\end{array}$ & $\begin{array}{c}-2.484 * * * \\
(0.603)\end{array}$ & $\begin{array}{c}-1.800 * * * \\
(0.544)\end{array}$ & $\begin{array}{c}0.154 \\
(0.359)\end{array}$ \\
\hline Loan Characteristics & YES & YES & YES & YES & YES & YES & YES & YES & YES & YES \\
\hline Borrower Characteristics & YES & YES & YES & YES & YES & YES & YES & YES & YES & YES \\
\hline Borrower Fixed Effects & NO & NO & NO & NO & NO & YES & YES & YES & YES & YES \\
\hline Year Fixed Effects & YES & YES & YES & YES & YES & YES & YES & YES & YES & YES \\
\hline Industry Fixed Effects & YES & YES & YES & YES & YES & YES & YES & YES & YES & YES \\
\hline Rating Fixed Effects & YES & YES & YES & YES & YES & YES & YES & YES & YES & YES \\
\hline Loan Type Fixed Effects & YES & YES & YES & YES & YES & YES & YES & YES & YES & YES \\
\hline Loan Purpose Fixed Effects & YES & YES & YES & YES & YES & YES & YES & YES & YES & YES \\
\hline Number of Observations & 4145 & 4074 & 3472 & 3472 & 1684 & 4145 & 4074 & 3472 & 3472 & 1684 \\
\hline $\mathrm{R}^{2}$ & 0.626 & 0.132 & 0.185 & 0.121 & 0.193 & 0.850 & 0.531 & 0.756 & 0.770 & 0.582 \\
\hline
\end{tabular}




\section{Table XI}

\section{Covenant Violations, Relationships and Loan Liquidity}

The table reports results from multivariate regressions using various dependent variables. These are the (1) number of lenders, (2) number of lenders over facility size, and (3) switch. All variables are described in Appendix I. Standard errors shown in parentheses are robust to heteroscedasticity and clustered at the firm level. The statistical significance of results is indicated by $*=10 \%$ level, $* *=5 \%$ level and $* * *=1 \%$ level.

\begin{tabular}{|c|c|c|c|}
\hline & (1) & (2) & (3) \\
\hline Dependent Variable & Number of Lenders & $\begin{array}{c}\text { Number of Lenders / } \\
\text { Facility Size }\end{array}$ & Switch \\
\hline Regression Methodology & OLS & OLS & Logit \\
\hline Prior Covenant Violation & $\begin{array}{c}0.224 \\
(0.443)\end{array}$ & $\begin{array}{c}0.003 \\
(0.004)\end{array}$ & $\begin{array}{c}0.122 \\
(0.148)\end{array}$ \\
\hline \multicolumn{4}{|l|}{ Loan Characteristics } \\
\hline Ln(Maturity in Months) & $\begin{array}{c}1.654 * * * \\
(0.498)\end{array}$ & $\begin{array}{c}-0.006 \\
(0.005)\end{array}$ & $\begin{array}{c}0.200 \\
(0.146)\end{array}$ \\
\hline Secured & $\begin{array}{c}0.730 \\
(0.512)\end{array}$ & $\begin{array}{c}0.013 * * \\
(0.005)\end{array}$ & $\begin{array}{c}0.191 \\
(0.172)\end{array}$ \\
\hline Log (Facility Size) & $\begin{array}{c}2.132 * * * \\
(0.189)\end{array}$ & & $\begin{array}{c}-0.150 * * \\
(0.061)\end{array}$ \\
\hline Ln(Number of Loans) & $\begin{array}{c}0.621 \\
(0.397)\end{array}$ & $\begin{array}{c}0.001 \\
(0.004)\end{array}$ & $\begin{array}{l}-0.259 * \\
(0.153)\end{array}$ \\
\hline Performance Pricing & $\begin{array}{c}1.862 * * * \\
(0.378)\end{array}$ & $\begin{array}{l}-0.005 \\
(0.005)\end{array}$ & $\begin{array}{l}-0.085 \\
(0.136)\end{array}$ \\
\hline \multicolumn{4}{|l|}{ Borrower Characteristics } \\
\hline Profitability & $\begin{array}{l}-0.005 \\
(0.020)\end{array}$ & $\begin{array}{c}0.000 \\
(0.000)\end{array}$ & $\begin{array}{c}0.001 \\
(0.006)\end{array}$ \\
\hline Current Ratio & $\begin{array}{l}-0.002 \\
(0.002)\end{array}$ & $\begin{array}{c}0.000 * * \\
(0.000)\end{array}$ & $\begin{array}{c}0.000 \\
(0.001)\end{array}$ \\
\hline Leverage & $\begin{array}{c}0.009 \\
(0.011)\end{array}$ & $\begin{array}{c}0.000 \\
(0.000)\end{array}$ & $\begin{array}{c}0.003 \\
(0.004)\end{array}$ \\
\hline Coverage & $\begin{array}{l}-0.000 \\
(0.000)\end{array}$ & $\begin{array}{c}-0.000 * \\
(0.000)\end{array}$ & $\begin{array}{c}0.000 * * \\
(0.000)\end{array}$ \\
\hline 5 year Profit Trend & $\begin{array}{c}-0.017 \\
(0.048)\end{array}$ & $\begin{array}{c}-0.001 \\
(0.001)\end{array}$ & $\begin{array}{l}-0.023 \\
(0.026)\end{array}$ \\
\hline Market to Book & $\begin{array}{c}0.002 \\
(0.003)\end{array}$ & $\begin{array}{c}-0.000 * * \\
(0.000)\end{array}$ & $\begin{array}{l}-0.002 * \\
(0.001)\end{array}$ \\
\hline Log (Total Assets) & $\begin{array}{c}1.552 * * * \\
(0.261)\end{array}$ & $\begin{array}{c}-0.014 * * * \\
(0.002)\end{array}$ & $\begin{array}{c}-0.189 * * \\
(0.088)\end{array}$ \\
\hline Constant & $\begin{array}{c}-25.293 * * * \\
(4.299) \\
\end{array}$ & $\begin{array}{c}0.162^{* * *} \\
(0.040)\end{array}$ & $\begin{array}{c}2.733 * * \\
(1.186)\end{array}$ \\
\hline Year Fixed Effects & YES & YES & YES \\
\hline Industry Fixed Effects & YES & YES & YES \\
\hline Rating Fixed Effects & YES & YES & YES \\
\hline Loan Type Fixed Effects & YES & YES & YES \\
\hline Loan Purpose Fixed Effects & YES & YES & YES \\
\hline Number of Observations & 2,826 & 2,826 & 2,779 \\
\hline $\mathrm{R}^{2}$ & 0.405 & 0.148 & 0.1073 \\
\hline
\end{tabular}




\section{Appendix I Variable Definitions}

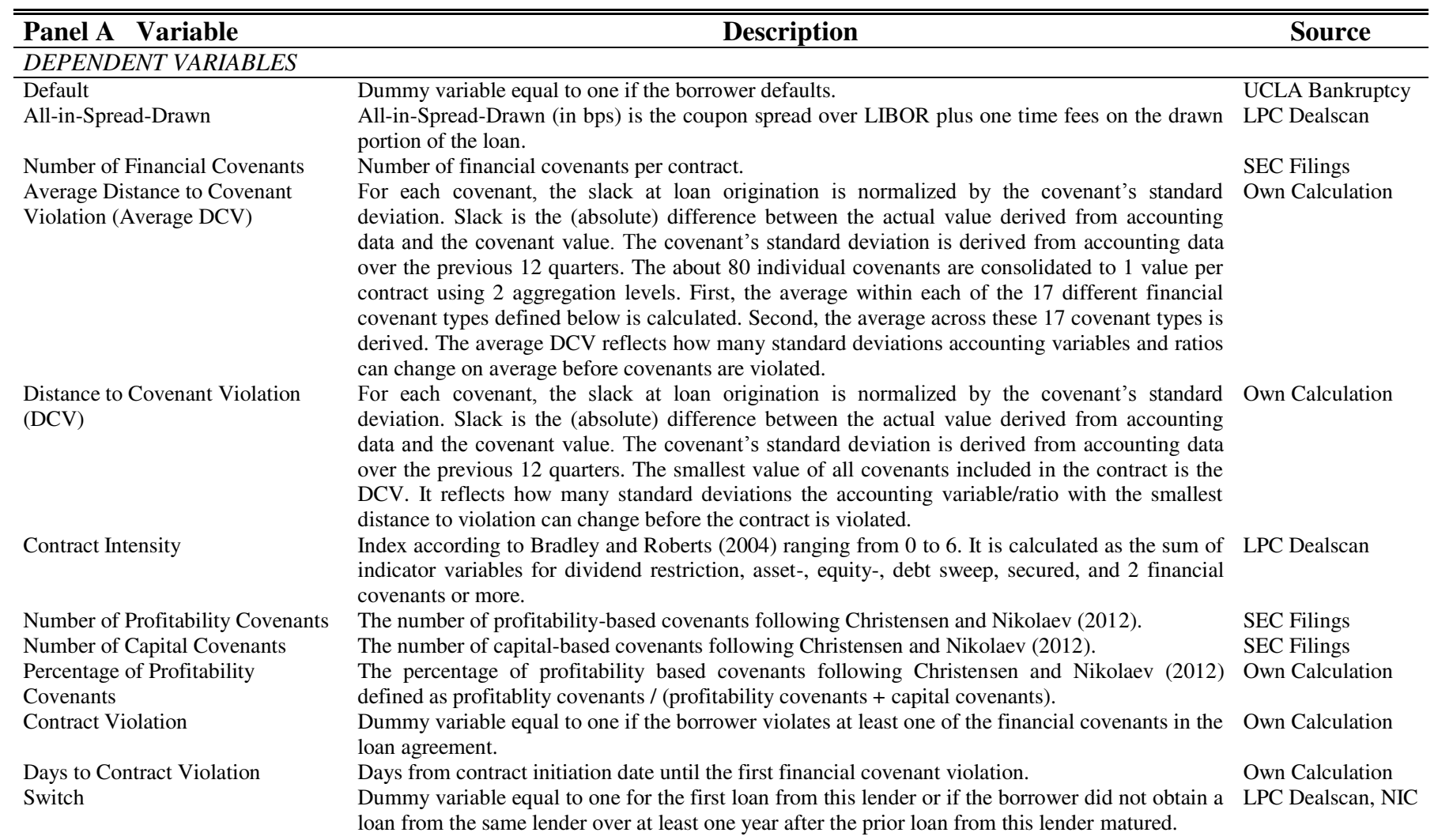

INDEPENDENT VARIABLES

Loan Characteristics

Prior Covenant Violation

Dummy variable equal to one if the borrower violated a covenant in the prior loan of our sample.

Own Calculation

Percentage of Covenants Violated

Number of covenants the borrower violated in the prior loan of our sample divided by the total

Own Calculation

Change in CEO

Dummy variable equal to one if the CEO of the borrowing firm changes in the period from a Execucomp covenant violation in the prior contract (initiation of the prior contract) until the initiation of the new contract when the borrower did (not) violate a covenant in the prior contract.

Facility Size Facility amount of the loan in year $2000 \$$ million.

Maturity of the loan in months.

Dummy variable equal to one if the loan is secured.

Secured

Number of loans the respective borrower has since the introduction of LPC Dealscan in 1987.

LPC Dealscan

LPC Dealscan

LPC Dealscan

Number of Loans

Dummy variable equal to one, if the loan contains a performance pricing grid.

Performance Pricing

Number of days from a covenant violation to the initiation of the subsequent new loan.

LPC Dealscan

Days Violation to Subsequent Loan

Loan Purpose

Corporate

Recapitalization

Dummy variable equal to one, if the loan issuance purpose is "General" in the database.

LPC Dealscan

Own Calculation

Acquisition

Dummy variable equal to one, if the loan issuance purpose is "Recapitalization" in the database.

LPC Dealscan

Dummy variable equal to one, if the loan issuance purpose is "Acquisition" in the database.

LPC Dealscan

LBO

Dummy variable equal to one, if the loan issuance purpose is "Leveraged Buy Out" in the LPC Dealscan database.

Back Up

Other

Dummy variable equal to one, if the loan issuance purpose is "Back Up" in the database.

LPC Dealscan Dummy variable equal to one, if the loan issuance purpose is "Other" in the database.

LPC Dealscan 


\section{Appendix I continued Variable Definitions}

\begin{tabular}{|c|c|c|}
\hline Panel A Variable & Description & Source \\
\hline \multicolumn{3}{|l|}{ Loan Characteristics continued } \\
\hline Revolver $<1$ Year & Dummy variable equal to one, if the loan type is "Revolver $<1$ Year" in the database. & LPC Dealscan \\
\hline Bridge Loan & Dummy variable equal to one, if the loan type is "Bridge Loan" in the database. & LPC Dealscan \\
\hline 364 - Day Facility & Dummy variable equal to one, if the loan type is " 364 - Day Facility" in the database. & LPC Dealscan \\
\hline Term Loan & Dummy variable equal to one, if the loan type is "Term Loan" in the database. & LPC Dealscan \\
\hline \multicolumn{3}{|l|}{ Borrower Characteristics } \\
\hline Current Ratio & Ratio of current assets to current liabilities. & Compustat \\
\hline Leverage Ratio & Ratio of book value of total debt to book value of total assets. & Compustat \\
\hline 5 year Profit Trend & $\begin{array}{l}\text { The trend of net income to total assets over the last } 5 \text { years of the firm. It is derived via a } \\
\text { regression of net income to total assets on a constant and a time trend and reflected by the latters' } \\
\text { coefficient. For its derivation, data starting in } 1991 \text { is used. }\end{array}$ & \\
\hline Coverage & Ratio of EBITDA to interest expenses. & Compustat \\
\hline Market to Book & $\begin{array}{l}\text { Ratio of the sum of book value of liabilities and market value of equity to book value of total } \\
\text { assets. }\end{array}$ & Compustat \\
\hline \multicolumn{3}{|c|}{ ( } \\
\hline Investment Grade Rating & Dummy variable equal to one, if the borrower's $\mathrm{S} \& \mathrm{P}$ long-term issuer rating is BBB- or better. & LPC Dealscan \\
\hline Non-Investment Grade Rating & Dummy variable equal to one, if the borrower's $\mathrm{S} \& \mathrm{P}$ long-term issuer rating is $\mathrm{BB}+$ or worse. & LPC Dealscan \\
\hline Not Rated & Dummy variable equal to one, if the borrower is not rated by S\&P. & LPC Dealscan \\
\hline \multicolumn{3}{|l|}{ Financial Covenants } \\
\hline Asset Coverage Ratio & Current Assets to Liabilities & SEC Filings \\
\hline Cash and Cash Equivalents & Cash and Cash Equivalents & SEC Filings \\
\hline Current Ratio & Current Assets to Current Liabilities & SEC Filings \\
\hline Debt Service Coverage Ratio & EBITDA to Interest Expense and Principal Payment & SEC Filings \\
\hline Debt to Capitalization & Debt to Capitalization (Total Debt and Equity) & SEC Filings \\
\hline Debt to EBITDA & Debt to EBITDA & SEC Filings \\
\hline Senior Debt to Net Worth & Senior Debt to Net Worth & SEC Filings \\
\hline Tangible Net Worth & Tangible Net Worth & SEC Filings \\
\hline Working Capital & Current Assets minus Current Liabilities & SEC Filings \\
\hline Profitability Covenants & $\begin{array}{l}\text { Debt to EBITDA, Debt Service Coverage Ratio, EBITDA, Fixed Charge Coverage Ratio, Interest } \\
\text { Coverage Ratio, Senior Debt to EBITDA }\end{array}$ & \\
\hline Capital Covenants & $\begin{array}{l}\text { Asset Coverage Ratio, Current Ratio, Debt to Capitalization, Debt to Net Worth, Net Worth, } \\
\text { Quick Ratio, Senior Debt to Capitalization, Senior Debt to Net Worth, Tangible Net Worth, } \\
\text { Working Capital }\end{array}$ & \\
\hline Leverage Covenant & Debt to Capitalization, Senior Debt to Capitalization & \\
\hline Net Worth Covenant & Debt to Net Worth, Net Worth, Senior Debt to Net Worth, Tangible Net Worth & \\
\hline Short-term Covenant & Asset Coverage Ratio, Current Ratio, Quick Ratio, Working Capital, Cash and Cash Equivalents & \\
\hline
\end{tabular}




\section{Appendix I continued Variable Definitions}

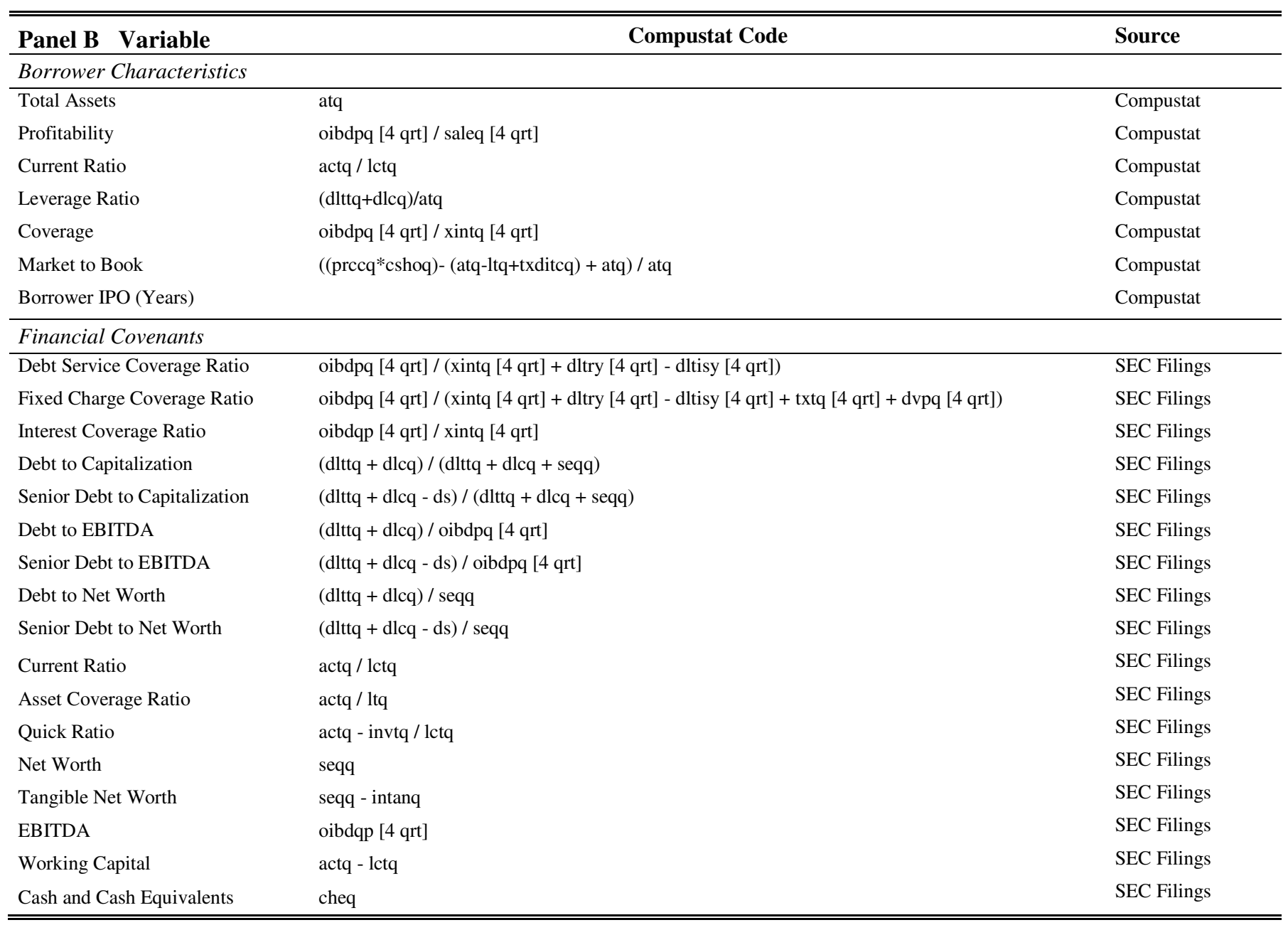




\section{Online Appendix}

\section{Online Appendix I}

SECTION 7.10. Certain Financial Covenants.

(a) Debt Ratio. The Borrower will not permit the Debt Ratio to exceed the following respective ratios at any time during the following respective periods:

Period

From the date hereof through August 31, 2000

From September 1, 2000 through August 31, 2001

From September 1, 2001

and at all times thereafter

\section{Ratio}

4.75 to 1

4.50 to 1

4.25 to 1

4.00 to 1

(b) Senior Debt Ratio. The Borrower will not permit the Senior Debt Ratio to exceed the following respective ratios at any time during the following respective periods:

\section{Period}

From the date hereof through February 29, 2000

From March 1, 2000 through August 31, 2000

From September 1, 2000

and at all times thereafter
Ratio

3.75 to 1

3.50 to 1

3.00 to 1

2.50 to 1

(c) Interest Coverage Ratio. The Borrower will not permit the Interest Coverage Ratio to be less than the following respective ratios at any time during the following respective periods:

Period

From the date hereof through August 31, 2000

From September 1, 2000 through August 31, 2001

From September 1, 2001

and at all times thereafter
Ratio

2.25 to 1

2.00 to 1

1.75 to 1

1.50 to 1

(d) Fixed-charges Ratio. The Borrower will not permit the

Fixed-charges Ratio to be less than 1.00 to 1 as at the last day of any fiscal quarter of each fiscal year. 


\section{Online Appendix II}

Company Name: Gray Communications Systems

Deal active date: July 31, 1998

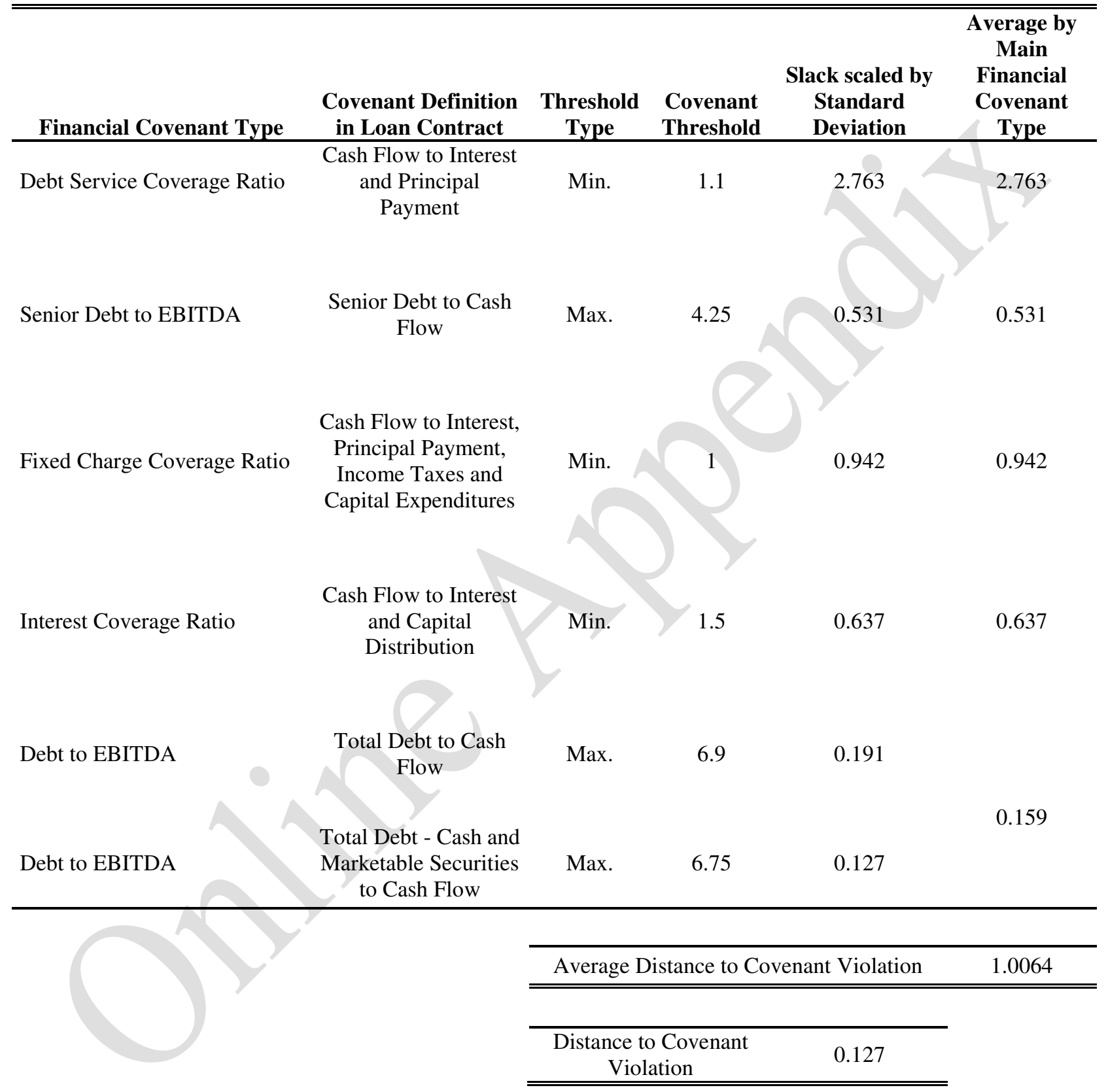




\section{Online Appendix II continued}

Exemplified Contract with a DCV of 1.50 of a Min. Threshold Type Covenant

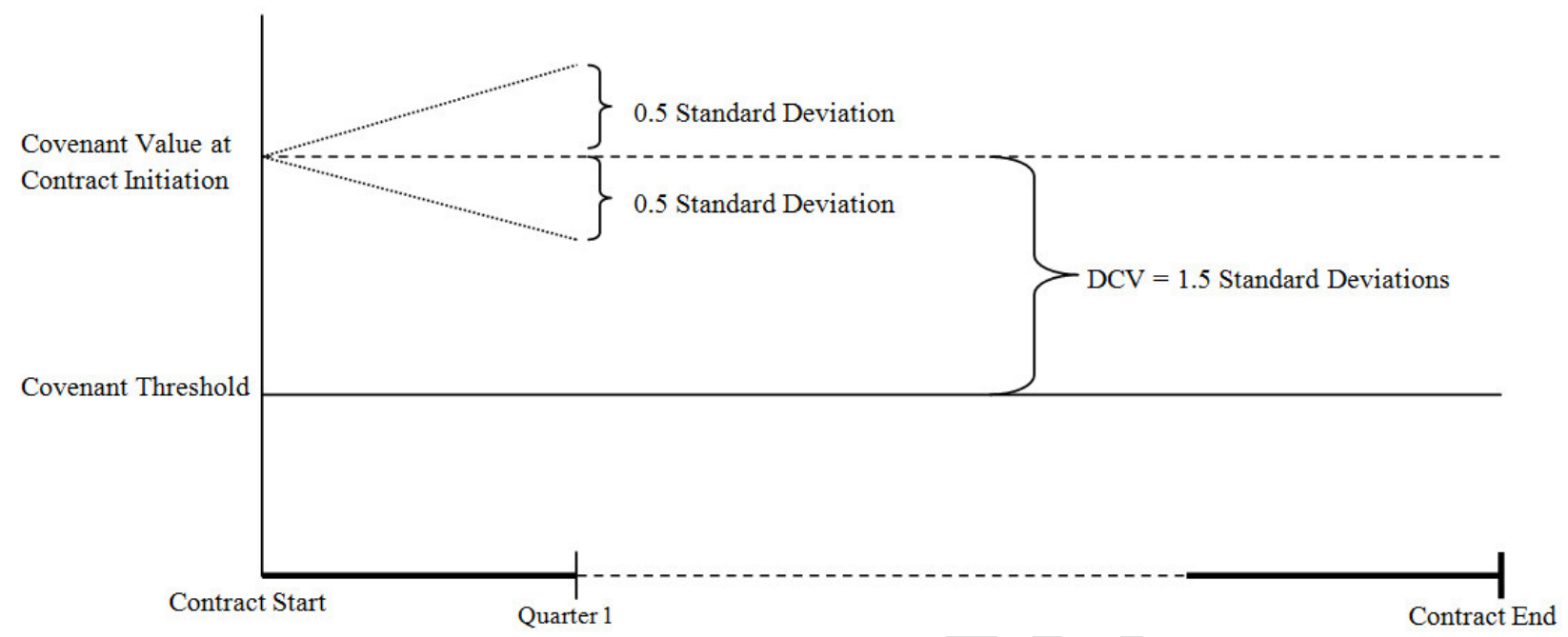

As an example for our covenant looseness measure consider the covenants in Gray Communications Systems' loan contract on July $31^{\text {st }}$, 1998. It contains 6 covenants in 5 main covenant types:

i. an adjusted debt service coverage ratio of 1.1 ,

ii. a senior debt to adjusted EBITDA ratio of 4.25 ,

iii. an adjusted fixed charge coverage ratio of 1 ,

iv. an adjusted interest coverage ratio of 1.5 ,

v. a debt to adjusted EBITDA ratio of 6.9, and

vi. an adjusted debt to adjusted EBITDA ratio of 6.75,

where the two latter both belong to the Debt to EBITDA covenant main type. "Adjusted" refers to any definition different from the variable on a stand-alone basis.

We derive the slack between each accounting variable as calculated prior to the loan and the specified covenant threshold in the loan contract and divide it by the financial covenant's standard deviation, derived over the previous 12 quarters. The accounting value for the adjusted debt service coverage ratio which is the cash flow to interest and principal payment on July 31 st, 1998 is 1.62 . Subtracting the covenant threshold of 1.1 and dividing the result by a standard deviation of 0.1882 gives a value of 2.763 . It reflects the fact that the Cash Flow to Interest and 
Principal Payment ratio may decrease 2.763 times its standard deviation of 0.1882 , i.e. by 0.52 , before the covenant is violated. A covenant is violated if the corresponding accounting value is above (a max. threshold type) or below (a min. threshold type) its respective threshold. The calculation for the other covenants follows the same approach.

The distance to covenant violation (DCV) is determined by the lowest value of all slacks scaled by the standard deviation. For the average DCV, these values are aggregated up to their main financial covenant type. Accordingly, the values for debt to adjusted EBITDA of 0.191 and adjusted debt to adjusted EBITDA ratio of 0.127 are averaged to 0.159 for the Debt to EBITDA main covenant type, where the remaining covenants all belong to different main types. Finally, the average DCV of 1.0064 is derived as the mean of all five main financial covenant types.

We provide another example showing our DCV measure graphically. It shows a contract with a DCV of 1.5. This implies that the financial value / ratio of the strictest covenant in a contract may deteriorate by 1.5 of its standard deviation before a contract is violated over its maturity. Given that after contract initiation this ratio would consecutively move in each quarter towards its threshold by 0.5 of its standard deviation this would accordingly imply that in the third quarter the financial value / ratio would be equal to the specified threshold in the contract and in the fourth quarter the contract would be in violation. 


\section{Online Appendix III}

\section{Profitability-Based versus Capital-Based Covenants}

This table shows univariate results of these covenants split into whether a covenant was violated in the prior loan ("Violation") or no covenant violation ("No Violation") occurred. The statistical significance of the difference, shown in the third column, between "Violation" and "No Violation" of each variable is tested via a t-test and a Wilcoxon rank sum test where the last two columns provide the corresponding $\mathrm{t}$ - and $\mathrm{z}$-statistic.

\begin{tabular}{|c|c|c|c|c|c|}
\hline \multirow{3}{*}{$\begin{array}{l}\text { Panel A: Profitability-based vs. } \\
\text { capital-based covenants }\end{array}$} & \multirow{3}{*}{$\begin{array}{c}\text { No Violation } \\
\text { (A) } \\
\text { Mean }\end{array}$} & \multirow{3}{*}{$\begin{array}{c}\text { Violation } \\
\text { (B) } \\
\text { Mean }\end{array}$} & \multirow{3}{*}{$\begin{array}{c}\text { Difference } \\
(\mathbf{A})-(\mathbf{B}) \\
\text { Mean }\end{array}$} & \multirow{2}{*}{\multicolumn{2}{|c|}{ (A) }} \\
\hline & & & & & \\
\hline & & & & t-statistics & \multirow{2}{*}{$\begin{array}{l}\text { Z-statistics } \\
-16.833^{* * *}\end{array}$} \\
\hline Profitability Covenants & 1.312 & 2.014 & $-0.707 * * *$ & $-18.557 * * *$ & \\
\hline Debt Service Coverage & 0.012 & 0.037 & $-0.026^{* * *}$ & $-4.542 * * *$ & $-4.203 * * *$ \\
\hline Debt to EBITDA & 0.497 & 0.709 & $-0.212 * * *$ & $-11.572 * * *$ & $-11.457 * * *$ \\
\hline EBITDA & 0.048 & 0.131 & $-0.083 * * *$ & $-7.940 * * *$ & $-7.394 * * *$ \\
\hline Fixed Charge Coverage & 0.244 & 0.494 & $-0.250 * * *$ & $-14.222 * * *$ & $-13.461 * * *$ \\
\hline Interest Coverage & 0.457 & 0.445 & 0.012 & 0.637 & 0.637 \\
\hline Senior Debt to EBITDA & 0.055 & 0.198 & $-0.143 * * *$ & $-11.991 * * *$ & $-10.906^{* * *}$ \\
\hline$\underline{\text { Capital Covenants }}$ & 0.665 & 0.555 & $0.109 * * *$ & $4.225 * * *$ & $5.107 * * *$ \\
\hline Asset Coverage Ratio & 0.006 & 0.017 & $-0.011 * * *$ & $-2.823 * * *$ & $-2.630 * * *$ \\
\hline Current Ratio & 0.023 & 0.063 & $-0.040^{* * *}$ & $-5.301 * * *$ & $-4.951 * * *$ \\
\hline Debt to Capitalization & 0.298 & 0.124 & $0.174 * * *$ & $11.199 * * *$ & $11.450 * * *$ \\
\hline Debt to Net Worth & 0.038 & 0.012 & $0.026 * * *$ & $4.175 * * *$ & $4.473 * * *$ \\
\hline Net Worth & 0.187 & 0.206 & -0.019 & -1.235 & -1.228 \\
\hline Quick Ratio & 0.013 & 0.007 & $0.006^{*}$ & $1.483^{*}$ & $1.544^{*}$ \\
\hline Senior Debt to Capitalization & 0.005 & 0.004 & 0.001 & 0.244 & 0.247 \\
\hline Senior Debt to Net Worth & 0.002 & 0.002 & 0.000 & 0.004 & 0.004 \\
\hline Tangible Net Worth & 0.087 & 0.113 & $-0.026 * *$ & $-2.276 * *$ & $-2.237 * *$ \\
\hline Working Capital & 0.004 & 0.006 & -0.002 & -0.762 & -0.741 \\
\hline
\end{tabular}




\section{NOT FOR PUBLICATION}

\section{Addition to Table III, Panel B}

\section{Dynamic Loan Contracting Following Covenant Violations in the Prior Loan}

The table reports results from multivariate regressions of various price and non-price loan contract terms on prior covenant violation and control variables. These are the (1) All-in-Spread-Drawn, (2) the number of financial covenants, (3) the average distance to covenant violation (DCV), (4) the DCV, and (5) the contract intensity. Prior covenant violation is a dummy variable equal to one if the borrower violated a financial covenant in the prior loan contract. All variables are described in Appendix 1. In Model (5) "Secured" is excluded as it is part of the dependent variable. Standard errors shown in parentheses are robust to heteroscedasticity and clustered at the firm level. The statistical significance of results is indicated by $*=10 \%$ level, $* *=5 \%$ level and $* * *=1 \%$ level.

\begin{tabular}{|c|c|c|c|c|c|}
\hline Including Borrower Fixed Effects & $(1)$ & $(2)$ & $(3)$ & $(3)$ & $(4)$ \\
\hline Dependent Variable & AISD & $\begin{array}{l}\text { Covenant } \\
\text { Number }\end{array}$ & Average DCV & DCV & $\begin{array}{l}\text { Contract } \\
\text { Intensity }\end{array}$ \\
\hline Regression Methodology & OLS & Ordered Logit & OLS & OLS & Ordered Logit \\
\hline Prior Covenant Violation & $\begin{array}{c}7.698^{* * *} \\
(3.143)\end{array}$ & $\begin{array}{c}0.176^{* * *} \\
(0.074)\end{array}$ & $\begin{array}{c}-1.383 * * * * \\
(0.265)\end{array}$ & $\begin{array}{c}-0.858^{* * * *} \\
(0.154)\end{array}$ & $\begin{array}{l}-0.130 \\
(0.217)\end{array}$ \\
\hline \multicolumn{6}{|l|}{ Loan Characteristics } \\
\hline Ln(Maturity in Months) & $\begin{array}{l}-6.034 \\
(7.447)\end{array}$ & $\begin{array}{c}0.223 \\
(0.263)\end{array}$ & $\begin{array}{c}0.112 \\
(0.374)\end{array}$ & $\begin{array}{c}0.180 \\
(0.312)\end{array}$ & $\begin{array}{c}0.282 \\
(0.363)\end{array}$ \\
\hline Secured & $\begin{array}{c}38.303 * * * \\
(10.684)\end{array}$ & $\begin{array}{c}0.520 \\
(0.326)\end{array}$ & $\begin{array}{c}0.265 \\
(0.713)\end{array}$ & $\begin{array}{c}0.433 \\
(0.481)\end{array}$ & \\
\hline Log (Facility Size) & $\begin{array}{c}-8.179 * * * \\
(2.802)\end{array}$ & $\begin{array}{c}0.025 \\
(0.071)\end{array}$ & $\begin{array}{c}-0.245^{*} \\
(0.145)\end{array}$ & $\begin{array}{l}-0.188 \\
(0.146)\end{array}$ & $\begin{array}{l}-0.062 \\
(0.069)\end{array}$ \\
\hline Ln(Number of Loans) & $\begin{array}{c}8.739 \\
(21.604)\end{array}$ & $\begin{array}{l}-0.033 \\
(0.681)\end{array}$ & $\begin{array}{l}-2.029 \\
(1.528)\end{array}$ & $\begin{array}{l}-0.947 \\
(1.382)\end{array}$ & $\begin{array}{l}-1.476 \\
(3.436)\end{array}$ \\
\hline Performance Pricing & $\begin{array}{c}-31.581 * * * \\
(5.632)\end{array}$ & $\begin{array}{l}0.314 * \\
(0.184)\end{array}$ & $\begin{array}{c}0.082 \\
(0.370)\end{array}$ & $\begin{array}{c}0.131 \\
(0.430)\end{array}$ & $\begin{array}{c}0.051 \\
(0.282)\end{array}$ \\
\hline Borrower Characteristics & & & & & \\
\hline Profitability & $\begin{array}{l}-0.417 \\
(0.729)\end{array}$ & $\begin{array}{c}0.003 \\
(0.015)\end{array}$ & $\begin{array}{c}0.003 \\
(0.028)\end{array}$ & $\begin{array}{l}-0.018 \\
(0.031)\end{array}$ & $\begin{array}{c}0.041 \\
(0.076)\end{array}$ \\
\hline Current Ratio & $\begin{array}{c}0.008 \\
(0.050)\end{array}$ & $\begin{array}{l}-0.000 \\
(0.002)\end{array}$ & $\begin{array}{l}0.008^{*} \\
(0.004)\end{array}$ & $\begin{array}{c}0.004 \\
(0.004)\end{array}$ & $\begin{array}{c}0.001 \\
(0.010)\end{array}$ \\
\hline Leverage & $\begin{array}{c}0.778 * * * \\
(0.240)\end{array}$ & $\begin{array}{l}-0.000 \\
(0.012)\end{array}$ & $\begin{array}{c}-0.047 * * \\
(0.018)\end{array}$ & $\begin{array}{c}-0.044 * * * \\
(0.016)\end{array}$ & $\begin{array}{l}-0.006 \\
(0.051)\end{array}$ \\
\hline Coverage & $\begin{array}{c}-0.001 \\
(0.001)\end{array}$ & $\begin{array}{l}-0.000 \\
(0.000)\end{array}$ & $\begin{array}{c}0.000 \\
(0.000)\end{array}$ & $\begin{array}{c}0.000 \\
(0.000)\end{array}$ & $\begin{array}{c}0.000 \\
(0.000)\end{array}$ \\
\hline 5 year Profit Trend & $\begin{array}{c}-0.601 \\
(1.546)\end{array}$ & $\begin{array}{c}0.055 \\
(0.055)\end{array}$ & $\begin{array}{c}0.097 \\
(0.139)\end{array}$ & $\begin{array}{c}0.030 \\
(0.074)\end{array}$ & $\begin{array}{c}0.056 \\
(0.182)\end{array}$ \\
\hline Market to Book & $\begin{array}{c}-0.189 * * * * \\
(0.071)\end{array}$ & $\begin{array}{l}-0.001 \\
(0.002)\end{array}$ & $\begin{array}{c}0.001 \\
(0.006)\end{array}$ & $\begin{array}{c}0.006 \\
(0.005)\end{array}$ & $\begin{array}{l}-0.000 \\
(0.012)\end{array}$ \\
\hline Log (Total Assets) & $\begin{array}{c}-14.381 * \\
(7.985)\end{array}$ & $\begin{array}{l}-0.344 \\
(0.307)\end{array}$ & $\begin{array}{c}0.322 \\
(0.545)\end{array}$ & $\begin{array}{c}0.539 \\
(0.461)\end{array}$ & $\begin{array}{l}-0.086 \\
(1.489)\end{array}$ \\
\hline Constant & $\begin{array}{c}486.668 * * * \\
(87.461) \\
\end{array}$ & YES & $\begin{array}{c}7.574 \\
(6.930) \\
\end{array}$ & $\begin{array}{l}-2.859 \\
(6.132) \\
\end{array}$ & YES \\
\hline Borrower Fixed Effects & YES & YES & YES & YES & YES \\
\hline Year Fixed Effects & YES & YES & YES & YES & YES \\
\hline Industry Fixed Effects & YES & YES & YES & YES & YES \\
\hline Rating Fixed Effects & YES & YES & YES & YES & YES \\
\hline Loan Type Fixed Effects & YES & YES & YES & YES & YES \\
\hline Loan Purpose Fixed Effects & YES & YES & YES & YES & YES \\
\hline Number of Observations & 2,786 & 2,709 & 2,272 & 2,272 & 848 \\
\hline $\mathrm{R}^{2}$ & 0.853 & 0.580 & 0.752 & 0.715 & 0.761 \\
\hline
\end{tabular}




\section{NOT FOR PUBLICATION}

\section{Addition to Table IV \\ Dynamic Loan Contracting Following Covenant Violations in the Prior Loan - Alternative Explanations - Credit Risk}

The table reports results from multivariate regressions of different dependent variables. These are a default indicator variable (Panel A), a rating downgrade indicator variable (Panel B), the change in firm net worth to total assets (Panel C), the change in firm leverage (Panel D), and the number of subsequent loss making quarters excluding the current quarter (Panel E). Borrower and loan characteristics are as in Table III. Covenant Violation in Panels A to E is a dummy variable equal to one if the borrower violates a financial covenant in year t. Panels A to E use annual data. Model (1) in Panels A and B reports results from a Cox proportional hazards model. The remaining models in both Panels show regressions of the respective dependent variable on (lagged) control variables. Panels $\mathrm{C}$ and $\mathrm{D}$ show regressions of differences of the respective dependent variable between year $t+x$ and year $t$ on control variables in year $\mathrm{t}-1$. Panel $\mathrm{E}$ uses the number of subsequent loss making quarters as dependent variable excluding the current quarter. In years with no financial covenant violation this is the number of loss making quarters after Q4 of the respective year, in years with financial covenant violation the control variables are used in Q4 of the previous year and the number of loss making quarters is calculated as the loss quarters after the violation. All variables are described in Appendix 1. Standard errors shown in parentheses are robust to heteroscedasticity and clustered at the firm level. The statistical significance of results is indicated by $*=10 \%$ level, $* *=5 \%$ level and $* * *=1 \%$ level.

\begin{tabular}{|c|c|c|c|c|c|c|}
\hline Panel A: Default & $(\mathbf{1})$ & $(2)$ & (3) & (4) & 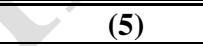 & (6) \\
\hline Dependent Variable & Default & $\begin{array}{c}\text { Default in } \\
t+1\end{array}$ & $\begin{array}{c}\text { Default in } \\
t+2\end{array}$ & $\begin{array}{c}\text { Default in } \\
t+3\end{array}$ & $\begin{array}{c}\text { Default in } \\
t+4\end{array}$ & $\begin{array}{c}\text { Default in } \\
t+5\end{array}$ \\
\hline Regression Methodology & Hazard Model & Logit & Logit & Logit & Logit & Logit \\
\hline Covenant Violation & $\begin{array}{l}-0.269 \\
(0.654)\end{array}$ & $\begin{array}{c}0.567 \\
(0.485)\end{array}$ & $\begin{array}{l}-0.396 \\
(0.605)\end{array}$ & $\begin{array}{l}0.196 \\
(0.529)\end{array}$ & $\begin{array}{l}-0.942 \\
(1.121)\end{array}$ & $\begin{array}{c}0.359 \\
(0.654)\end{array}$ \\
\hline Borrower Characteristics & & & & & & \\
\hline Profitability & $\begin{array}{l}-0.159 \\
(1.127)\end{array}$ & $\begin{array}{l}-2.985^{*} \\
(1.526)\end{array}$ & $\begin{array}{l}-2.702 \\
(1.671)\end{array}$ & $\begin{array}{l}-1.505 \\
(1.697)\end{array}$ & $\begin{array}{l}-1.307 \\
(1.722)\end{array}$ & $\begin{array}{l}-1.250 \\
(2.509)\end{array}$ \\
\hline Current Ratio & $\begin{array}{c}0.448 * * * \\
(0.120)\end{array}$ & $\begin{array}{l}-0.962 \\
(0.687)\end{array}$ & $\begin{array}{l}0.051 \\
(0.184)\end{array}$ & $\begin{array}{c}0.190 \\
(0.126)\end{array}$ & $\begin{array}{c}0.317 * * \\
(0.145)\end{array}$ & $\begin{array}{c}0.131 \\
(0.328)\end{array}$ \\
\hline Leverage & $\begin{array}{c}8.173 * * * \\
(1.287)\end{array}$ & $\begin{array}{c}11.895^{* * * *} \\
(1.918)\end{array}$ & $\begin{array}{c}5.002 * * * \\
(0.968)\end{array}$ & $\begin{array}{c}2.396 * * * \\
(0.878)\end{array}$ & $\begin{array}{c}3.715 * * * \\
(0.964)\end{array}$ & $\begin{array}{c}2.920 * * * \\
(1.104)\end{array}$ \\
\hline Coverage & $\begin{array}{l}-0.026 \\
(0.016)\end{array}$ & $\begin{array}{l}-0.046 \\
(0.078)\end{array}$ & $\begin{array}{l}-0.007 \\
(0.012)\end{array}$ & $\begin{array}{l}-0.005 \\
(0.014)\end{array}$ & $\begin{array}{c}0.000 \\
(0.009)\end{array}$ & $\begin{array}{c}0.006 \\
(0.007)\end{array}$ \\
\hline 5 year Profit Trend & $\begin{array}{c}-0.224 * * * \\
(0.040)\end{array}$ & $\begin{array}{l}-0.055 \\
(0.050)\end{array}$ & $\begin{array}{c}-0.142 * * * \\
(0.046)\end{array}$ & $\begin{array}{c}-0.078^{* *} \\
(0.039)\end{array}$ & $\begin{array}{c}0.008 \\
(0.061)\end{array}$ & $\begin{array}{c}0.009 \\
(0.059)\end{array}$ \\
\hline Market to Book & $\begin{array}{c}-1.371^{* *} \\
(0.576)\end{array}$ & $\begin{array}{c}-4.992 * * * \\
(1.079)\end{array}$ & $\begin{array}{c}-2.423 * * * \\
(0.605)\end{array}$ & $\begin{array}{l}-0.885^{*} \\
(0.515)\end{array}$ & $\begin{array}{l}-0.690 \\
(0.635)\end{array}$ & $\begin{array}{c}-0.886^{* *} \\
(0.449)\end{array}$ \\
\hline Log (Total Assets) & $\begin{array}{c}0.817 * * * \\
(0.108)\end{array}$ & $\begin{array}{c}0.509 * * * \\
(0.110)\end{array}$ & $\begin{array}{c}0.538 * * * \\
(0.099)\end{array}$ & $\begin{array}{c}0.581 * * * \\
(0.106)\end{array}$ & $\begin{array}{c}0.516^{* * * *} \\
(0.117)\end{array}$ & $\begin{array}{c}0.454 * * * \\
(0.132)\end{array}$ \\
\hline Constant & NO & $\begin{array}{c}-25.347 * * * \\
(2.248)\end{array}$ & $\begin{array}{c}-9.995 * * * \\
(1.820)\end{array}$ & $\begin{array}{c}-10.305^{* * *} \\
(1.772)\end{array}$ & $\begin{array}{c}-11.285 * * * \\
(2.219)\end{array}$ & $\begin{array}{c}-23.415^{* * * *} \\
(1.965)\end{array}$ \\
\hline Year Fixed Effects & YES & YES & YES & YES & YES & YES \\
\hline Industry Fixed Effects & YES & YES & YES & YES & YES & YES \\
\hline Rating Fixed Effects & YES & YES & YES & YES & YES & YES \\
\hline $\begin{array}{l}\text { Number of Observations } \\
\mathrm{R}^{2}\end{array}$ & 16,213 & $\begin{array}{c}12,663 \\
0.427\end{array}$ & $\begin{array}{c}11,772 \\
0.248\end{array}$ & $\begin{array}{c}10,646 \\
0.161\end{array}$ & $\begin{array}{l}9,031 \\
0.150\end{array}$ & $\begin{array}{l}7,510 \\
0.146\end{array}$ \\
\hline
\end{tabular}


NOT FOR PUBLICATION

Addition to Table IV continued

Dynamic Loan Contracting Following Covenant Violations in the Prior Loan - Alternative Explanations - Credit Risk

\begin{tabular}{|c|c|c|c|c|c|c|c|c|c|c|c|}
\hline $\begin{array}{l}\text { Panel B: Rating } \\
\text { Downgrade }\end{array}$ & (1) & (2) & (3) & (4) & (5) & (6) & (7) & (8) & (9) & (10) & (11) \\
\hline Dependent Variable & $\begin{array}{c}\text { Downgrad } \\
\text { e }\end{array}$ & $\begin{array}{c}\text { Downgrad } \\
e \text { in } t+1\end{array}$ & $\begin{array}{l}\text { Downgrad } \\
\text { e in } t+2\end{array}$ & $\begin{array}{c}\text { Downgrad } \\
e \text { in } t+3\end{array}$ & $\begin{array}{l}\text { Downgrad } \\
\text { e in } t+4\end{array}$ & $\begin{array}{l}\text { Downgrad } \\
\text { e in } t+5\end{array}$ & $\begin{array}{c}\text { Downgrad } \\
e \text { in } t+1\end{array}$ & $\begin{array}{c}\text { Downgrad } \\
\mathrm{e} \text { in } \mathrm{t}+2\end{array}$ & $\begin{array}{l}\text { Downgrad } \\
\text { e in } t+3\end{array}$ & $\begin{array}{l}\text { Downgrad } \\
\text { e in } t+4\end{array}$ & $\begin{array}{c}\text { Downgrad } \\
\text { e in } t+5\end{array}$ \\
\hline Regression Methodology & $\begin{array}{l}\text { Hazard } \\
\text { Model }\end{array}$ & Logit & Logit & Logit & Logit & Logit & Logit & Logit & Logit & Logit & Logit \\
\hline Covenant Violation & $\begin{array}{l}0.208 \\
(0.172)\end{array}$ & $\begin{array}{c}0.179 \\
(0.141)\end{array}$ & $\begin{array}{c}0.294 * * \\
(0.123)\end{array}$ & $\begin{array}{l}0.253 * \\
(0.132)\end{array}$ & $\begin{array}{c}0.185 \\
(0.154)\end{array}$ & $\begin{array}{c}0.134 \\
(0.199)\end{array}$ & $\begin{array}{c}0.059 \\
(0.184)\end{array}$ & $\begin{array}{c}0.238 \\
(0.180)\end{array}$ & $\begin{array}{c}0.281 \\
(0.208)\end{array}$ & $\begin{array}{c}0.121 \\
(0.272)\end{array}$ & $\begin{array}{c}0.122 \\
(0.557)\end{array}$ \\
\hline \multicolumn{12}{|l|}{ Borrower Characteristics } \\
\hline Profitability & $\begin{array}{c}-1.369 * * * \\
(0.373)\end{array}$ & $\begin{array}{c}-1.851 * * * \\
(0.385)\end{array}$ & $\begin{array}{c}-1.135 * * * \\
(0.396)\end{array}$ & $\begin{array}{l}-0.817^{*} \\
(0.446)\end{array}$ & $\begin{array}{l}-0.723 \\
(0.479)\end{array}$ & $\begin{array}{l}-0.486 \\
(0.553)\end{array}$ & $\begin{array}{c}-3.348 * * * \\
(0.800)\end{array}$ & $\begin{array}{l}-2.786 * * * \\
(0.960)\end{array}$ & $\begin{array}{l}-2.945 * * \\
(1.241)\end{array}$ & $\begin{array}{c}-3.413 * * \\
(1.412)\end{array}$ & $\begin{array}{l}-1.080 \\
(2.265)\end{array}$ \\
\hline Current Ratio & $\begin{array}{l}0.086 \\
(0.054)\end{array}$ & $\begin{array}{l}0.134 * * \\
(0.055)\end{array}$ & $\begin{array}{c}0.204 * * * \\
(0.052)\end{array}$ & $\begin{array}{c}0.249 * * * \\
(0.058)\end{array}$ & $\begin{array}{c}0.275 * * * \\
(0.065)\end{array}$ & $\begin{array}{c}0.304 * * * \\
(0.076)\end{array}$ & $\begin{array}{c}0.021 \\
(0.113)\end{array}$ & $\begin{array}{l}0.046 \\
(0.121)\end{array}$ & $\begin{array}{c}0.109 \\
(0.152)\end{array}$ & $\begin{array}{c}0.214 \\
(0.183)\end{array}$ & $\begin{array}{l}0.216 \\
(0.205)\end{array}$ \\
\hline Leverage & $\begin{array}{c}1.784 * * * \\
(0.376)\end{array}$ & $\begin{array}{c}1.925 * * * \\
(0.364)\end{array}$ & $\begin{array}{c}1.611 * * * \\
(0.376)\end{array}$ & $\begin{array}{c}1.332 * * * \\
(0.406)\end{array}$ & $\begin{array}{c}1.212 * * * \\
(0.449)\end{array}$ & $\begin{array}{c}1.174 * * \\
(0.484)\end{array}$ & $\begin{array}{c}5.215^{* * * *} \\
(0.736)\end{array}$ & $\begin{array}{c}4.114 * * * \\
(0.892)\end{array}$ & $\begin{array}{c}3.578 * * * \\
(1.081)\end{array}$ & $\begin{array}{l}3.204 * * \\
(1.525)\end{array}$ & $\begin{array}{c}2.578 \\
(1.913)\end{array}$ \\
\hline Coverage & $\begin{array}{c}0.002 \\
(0.004)\end{array}$ & $\begin{array}{c}0.001 \\
(0.004)\end{array}$ & $\begin{array}{l}-0.002 \\
(0.003)\end{array}$ & $\begin{array}{l}-0.004 \\
(0.003)\end{array}$ & $\begin{array}{l}-0.004 \\
(0.003)\end{array}$ & $\begin{array}{l}-0.002 \\
(0.004)\end{array}$ & $\begin{array}{l}-0.002 \\
(0.007)\end{array}$ & $\begin{array}{l}-0.002 \\
(0.006)\end{array}$ & $\begin{array}{l}-0.003 \\
(0.006)\end{array}$ & $\begin{array}{l}-0.007 \\
(0.008)\end{array}$ & $\begin{array}{c}0.006 \\
(0.009)\end{array}$ \\
\hline 5 year Profit Trend & $\begin{array}{l}-0.036^{*} \\
(0.021)\end{array}$ & $\begin{array}{c}-0.037 * * \\
(0.018)\end{array}$ & $\begin{array}{l}-0.023 \\
(0.019)\end{array}$ & $\begin{array}{l}-0.013 \\
(0.019)\end{array}$ & $\begin{array}{l}-0.010 \\
(0.020)\end{array}$ & $\begin{array}{l}0.001 \\
(0.022)\end{array}$ & $\begin{array}{c}-0.048 * * \\
(0.023)\end{array}$ & $\begin{array}{c}-0.077 \text { *** } \\
(0.029)\end{array}$ & $\begin{array}{c}-0.087 \text { *** } \\
(0.034)\end{array}$ & $\begin{array}{c}-0.102 * * \\
(0.042)\end{array}$ & $\begin{array}{c}-0.104^{*} \\
(0.058)\end{array}$ \\
\hline Market to Book & $\begin{array}{c}-0.627 * * * \\
(0.110)\end{array}$ & $\begin{array}{c}-0.890 * * * \\
(0.120)\end{array}$ & $\begin{array}{c}-0.668 * * * \\
(0.102)\end{array}$ & $\begin{array}{c}-0.517 * * * * \\
(0.094)\end{array}$ & $\begin{array}{c}-0.469 * * * \\
(0.094)\end{array}$ & $\begin{array}{c}-0.496 * * * \\
(0.099)\end{array}$ & $\begin{array}{c}-1.608 * * * * \\
(0.254)\end{array}$ & $\begin{array}{c}-1.029 * * * \\
(0.207)\end{array}$ & $\begin{array}{c}-0.593 * * * * \\
(0.218)\end{array}$ & $\begin{array}{l}-0.218 \\
(0.234)\end{array}$ & $\begin{array}{l}-0.010 \\
(0.247)\end{array}$ \\
\hline Log (Total Assets) & $\begin{array}{l}-0.015 \\
(0.049)\end{array}$ & $\begin{array}{l}-0.016 \\
(0.044)\end{array}$ & $\begin{array}{l}-0.017 \\
(0.047)\end{array}$ & $\begin{array}{l}-0.035 \\
(0.054)\end{array}$ & $\begin{array}{l}-0.068 \\
(0.060)\end{array}$ & $\begin{array}{l}-0.104 \\
(0.069)\end{array}$ & $\begin{array}{l}-0.189 \\
(0.233)\end{array}$ & $\begin{array}{c}0.214 \\
(0.269)\end{array}$ & $\begin{array}{l}0.584 * \\
(0.340)\end{array}$ & $\begin{array}{c}0.481 \\
(0.449)\end{array}$ & $\begin{array}{c}0.218 \\
(0.601)\end{array}$ \\
\hline Constant & & $\begin{array}{c}-1.616^{* * * *} \\
(0.535) \\
\end{array}$ & $\begin{array}{c}-1.129 * * \\
(0.546) \\
\end{array}$ & $\begin{array}{l}-0.666 \\
(0.602) \\
\end{array}$ & $\begin{array}{c}0.069 \\
(0.668) \\
\end{array}$ & $\begin{array}{c}0.654 \\
(0.751) \\
\end{array}$ & $\begin{array}{c}1.428 \\
(1.734) \\
\end{array}$ & $\begin{array}{c}0.605 \\
(1.920) \\
\end{array}$ & $\begin{array}{c}0.249 \\
(2.402) \\
\end{array}$ & $\begin{array}{c}5.170 \\
(3.153) \\
\end{array}$ & $\begin{array}{c}17.586^{* * * *} \\
(4.386) \\
\end{array}$ \\
\hline Borrower Fixed Effects & NO & NO & NO & $\mathrm{NO}$ & $\mathrm{NO}$ & NO & YES & YES & YES & YES & YES \\
\hline Year Fixed Effects & YES & YES & YES & YES & YES & YES & YES & YES & YES & YES & YES \\
\hline Industry Fixed Effects & YES & YES & YES & YES & YES & YES & YES & YES & YES & YES & YES \\
\hline Rating Fixed Effects & YES & YES & YES & YES & YES & YES & YES & YES & YES & YES & YES \\
\hline Number of Observations & 12,755 & 6,623 & 5,885 & 5,189 & 4,542 & 3,914 & 5,016 & 4,492 & 3,920 & 3,339 & 2,662 \\
\hline $\mathrm{R}^{2}$ & & 0.0771 & 0.0624 & 0.0620 & 0.0703 & 0.0866 & 0.228 & 0.294 & 0.374 & 0.484 & 0.578 \\
\hline
\end{tabular}


NOT FOR PUBLICATION

Addition to Table IV continued

Dynamic Loan Contracting Following Covenant Violations in the Prior Loan - Alternative Explanations - Credit Risk

\begin{tabular}{|c|c|c|c|c|c|c|c|c|c|c|}
\hline $\begin{array}{l}\text { Panel C: Change in Net } \\
\text { Worth / Total Assets }\end{array}$ & (1) & (2) & (3) & (4) & (5) & (6) & (7) & (8) & (9) & (10) \\
\hline Dependent Variable & $\begin{array}{c}\text { Change } \\
\text { from t to } t+1\end{array}$ & $\begin{array}{c}\text { Change } \\
\text { from } t \text { to } t+2\end{array}$ & $\begin{array}{c}\text { Change } \\
\text { from } t \text { to } t+3\end{array}$ & $\begin{array}{c}\text { Change } \\
\text { from } t \text { to } \\
t+4\end{array}$ & $\begin{array}{c}\text { Change } \\
\text { from } t \text { to } \\
t+5\end{array}$ & $\begin{array}{c}\text { Change } \\
\text { from } t \text { to } \\
t+1\end{array}$ & $\begin{array}{c}\text { Change } \\
\text { from } t \text { to } \\
t+2\end{array}$ & $\begin{array}{c}\text { Change } \\
\text { from } t \text { to } \\
t+3\end{array}$ & $\begin{array}{c}\text { Change } \\
\text { from } t \text { to } \\
t+4\end{array}$ & $\begin{array}{c}\text { Change } \\
\text { from } t \text { to } \\
t+5\end{array}$ \\
\hline Regression Methodology & OLS & OLS & OLS & OLS & OLS & OLS & OLS & OLS & OLS & OLS \\
\hline Covenant Violation & $\begin{array}{l}-0.628 \\
(0.405)\end{array}$ & $\begin{array}{c}-1.349 * * \\
(0.644)\end{array}$ & $\begin{array}{l}-0.142 \\
(0.783)\end{array}$ & $\begin{array}{l}-0.795 \\
(0.983)\end{array}$ & $\begin{array}{l}-1.088 \\
(1.241)\end{array}$ & $\begin{array}{c}-0.940 * * \\
(0.438)\end{array}$ & $\begin{array}{c}-1.629 * * \\
(0.644)\end{array}$ & $\begin{array}{l}-0.517 \\
(0.702)\end{array}$ & $\begin{array}{l}-1.075 \\
(0.833)\end{array}$ & $\begin{array}{l}-1.413 \\
(0.946)\end{array}$ \\
\hline \multicolumn{11}{|l|}{ Borrower Characteristics } \\
\hline Profitability & $\begin{array}{c}3.304 * * * \\
(1.078)\end{array}$ & $\begin{array}{l}3.914 * * \\
(1.723)\end{array}$ & $\begin{array}{c}4.753 * * \\
(2.214)\end{array}$ & $\begin{array}{l}5.348^{*} \\
(2.752)\end{array}$ & $\begin{array}{l}4.125 \\
(3.289)\end{array}$ & $\begin{array}{l}4.275^{* *} \\
(1.985)\end{array}$ & $\begin{array}{l}5.087 * * \\
(2.524)\end{array}$ & $\begin{array}{l}6.228 * * \\
(3.070)\end{array}$ & $\begin{array}{l}6.905 * * \\
(3.224)\end{array}$ & $\begin{array}{c}1.990 \\
(3.420)\end{array}$ \\
\hline Current Ratio & $\begin{array}{c}0.110 \\
(0.117)\end{array}$ & $\begin{array}{c}0.194 \\
(0.204)\end{array}$ & $\begin{array}{c}0.359 \\
(0.275)\end{array}$ & $\begin{array}{c}0.518 \\
(0.334)\end{array}$ & $\begin{array}{l}0.821 * * \\
(0.384)\end{array}$ & $\begin{array}{l}-0.280 \\
(0.201)\end{array}$ & $\begin{array}{l}-0.464 \\
(0.298)\end{array}$ & $\begin{array}{l}-0.305 \\
(0.312)\end{array}$ & $\begin{array}{l}-0.270 \\
(0.368)\end{array}$ & $\begin{array}{c}0.116 \\
(0.400)\end{array}$ \\
\hline Leverage & $\begin{array}{l}15.035^{* * * *} \\
(0.833)\end{array}$ & $\begin{array}{l}27.825 * * * \\
(1.475)\end{array}$ & $\begin{array}{l}37.689 * * * \\
(1.959)\end{array}$ & $\begin{array}{l}44.714 * * * \\
(2.374)\end{array}$ & $\begin{array}{c}52.279 * * * \\
(2.912)\end{array}$ & $\begin{array}{l}39.993 * * * \\
(1.542)\end{array}$ & $\begin{array}{l}73.223 * * * \\
(2.419)\end{array}$ & $\begin{array}{l}96.764 * * * \\
(2.637)\end{array}$ & $\begin{array}{l}110.584 * * * \\
(2.702)\end{array}$ & $\begin{array}{l}122.299 * * * \\
\quad(3.162)\end{array}$ \\
\hline Coverage & $\begin{array}{l}-0.006^{*} \\
(0.004)\end{array}$ & $\begin{array}{l}-0.008 \\
(0.007)\end{array}$ & $\begin{array}{l}-0.004 \\
(0.009)\end{array}$ & $\begin{array}{l}-0.009 \\
(0.010)\end{array}$ & $\begin{array}{l}-0.010 \\
(0.011)\end{array}$ & $\begin{array}{l}-0.012 * * \\
(0.005)\end{array}$ & $\begin{array}{c}-0.016^{* *} \\
(0.007)\end{array}$ & $\begin{array}{l}-0.009 \\
(0.009)\end{array}$ & $\begin{array}{l}-0.011 \\
(0.010)\end{array}$ & $\begin{array}{l}-0.014 \\
(0.011)\end{array}$ \\
\hline 5 year Profit Trend & $\begin{array}{l}-0.019 \\
(0.045)\end{array}$ & $\begin{array}{l}-0.029 \\
(0.074)\end{array}$ & $\begin{array}{l}-0.094 \\
(0.097)\end{array}$ & $\begin{array}{l}-0.188^{*} \\
(0.106)\end{array}$ & $\begin{array}{l}-0.218^{*} \\
(0.119)\end{array}$ & $\begin{array}{c}0.087 \\
(0.053)\end{array}$ & $\begin{array}{l}0.158 * * \\
(0.077)\end{array}$ & $\begin{array}{l}0.162 * \\
(0.087)\end{array}$ & $\begin{array}{c}0.111 \\
(0.083)\end{array}$ & $\begin{array}{c}0.136 \\
(0.088)\end{array}$ \\
\hline Market to Book & $\begin{array}{c}0.849 * * * \\
(0.123)\end{array}$ & $\begin{array}{c}1.129 * * * \\
(0.211)\end{array}$ & $\begin{array}{c}1.096 * * * \\
(0.279)\end{array}$ & $\begin{array}{c}1.175^{* * * *} \\
(0.333)\end{array}$ & $\begin{array}{c}1.116^{* * * *} \\
(0.405)\end{array}$ & $\begin{array}{c}1.664 * * * \\
(0.209)\end{array}$ & $\begin{array}{c}1.897 * * * \\
(0.323)\end{array}$ & $\begin{array}{c}1.556 * * * \\
(0.384)\end{array}$ & $\begin{array}{c}1.433 * * * \\
(0.382)\end{array}$ & $\begin{array}{c}1.515 * * * \\
(0.382)\end{array}$ \\
\hline Log (Total Assets) & $\begin{array}{c}-0.252 * * * \\
(0.084)\end{array}$ & $\begin{array}{c}-0.567 * * * * \\
(0.150)\end{array}$ & $\begin{array}{c}-0.979 * * * \\
(0.205)\end{array}$ & $\begin{array}{c}-1.222 * * * \\
(0.257)\end{array}$ & $\begin{array}{c}-1.394 * * * \\
(0.314)\end{array}$ & $\begin{array}{l}-0.392 \\
(0.353)\end{array}$ & $\begin{array}{c}-1.563^{* * *} \\
(0.617)\end{array}$ & $\begin{array}{c}-3.080 * * * \\
(0.773)\end{array}$ & $\begin{array}{c}-3.643 * * * \\
(0.833)\end{array}$ & $\begin{array}{c}-3.861 * * * \\
(0.849)\end{array}$ \\
\hline Constant & $\begin{array}{c}-11.476^{* * * *} \\
(1.101)\end{array}$ & $\begin{array}{c}-20.738 * * * \\
(1.854) \\
\end{array}$ & $\begin{array}{c}-24.301 * * * \\
(2.397)\end{array}$ & $\begin{array}{c}-26.991 * * * \\
(2.986) \\
\end{array}$ & $\begin{array}{c}-28.790^{* * * *} \\
(3.573)\end{array}$ & $\begin{array}{c}-10.282 * * * * \\
(2.921)\end{array}$ & $\begin{array}{c}-16.269^{* * * *} \\
(4.376) \\
\end{array}$ & $\begin{array}{c}-131.956 * * * \\
(3.755) \\
\end{array}$ & $\begin{array}{c}-61.597 * * * * \\
(2.641) \\
\end{array}$ & $\begin{array}{c}-59.726 * * * \\
(3.735) \\
\end{array}$ \\
\hline Borrower Fixed Effects & $\mathrm{NO}$ & NO & NO & NO & $\mathrm{NO}$ & YES & YES & YES & YES & YES \\
\hline Year Fixed Effects & YES & YES & YES & YES & YES & YES & YES & YES & YES & YES \\
\hline Industry Fixed Effects & YES & YES & YES & YES & YES & YES & YES & YES & YES & YES \\
\hline Rating Fixed Effects & YES & YES & YES & YES & YES & YES & YES & YES & YES & YES \\
\hline Number of Observations & 15,002 & 13,572 & 12,194 & 10,886 & 9,628 & 15,002 & 13,572 & 12,194 & 10,886 & 9,628 \\
\hline $\mathrm{R}^{2}$ & 0.078 & 0.124 & 0.156 & 0.179 & 0.200 & 0.242 & 0.405 & 0.522 & 0.609 & 0.683 \\
\hline
\end{tabular}




\section{NOT FOR PUBLICATION}

Addition to Table IV continued

Dynamic Loan Contracting Following Covenant Violations in the Prior Loan - Alternative Explanations - Credit Risk

\begin{tabular}{|c|c|c|c|c|c|c|c|c|c|c|}
\hline Panel D: Change in Leverage & (1) & $(2)$ & (3) & (4) & $(5)$ & $(6)$ & $(7)$ & $(8)$ & (9) & (10) \\
\hline Dependent Variable & $\begin{array}{c}\text { Change } \\
\text { from } t \text { to } \\
t+1\end{array}$ & $\begin{array}{c}\text { Change } \\
\text { from } t \text { to } \\
t+2\end{array}$ & $\begin{array}{c}\text { Change } \\
\text { from } t \text { to } \\
t+3\end{array}$ & $\begin{array}{c}\text { Change } \\
\text { from } t \text { to } \\
t+4\end{array}$ & $\begin{array}{c}\text { Change } \\
\text { from to to } \\
t+5\end{array}$ & $\begin{array}{c}\text { Change } \\
\text { from } t \text { to } \\
t+1\end{array}$ & $\begin{array}{c}\text { Change } \\
\text { from } t \text { to } \\
t+2\end{array}$ & $\begin{array}{c}\text { Change } \\
\text { from t to } \\
t+3\end{array}$ & $\begin{array}{c}\text { Change } \\
\text { from } t \text { to } \\
t+4\end{array}$ & $\begin{array}{c}\text { Change } \\
\text { from to to } \\
t+5\end{array}$ \\
\hline Regression Methodology & OLS & OLS & OLS & OLS & OLS & OLS & OLS & OLS & OLS & OLS \\
\hline Covenant Violation & $\begin{array}{c}0.201 \\
(0.331)\end{array}$ & $\begin{array}{c}0.594 \\
(0.531)\end{array}$ & $\begin{array}{l}-0.031 \\
(0.673)\end{array}$ & $\begin{array}{c}0.371 \\
(0.810)\end{array}$ & $\begin{array}{c}0.404 \\
(1.023)\end{array}$ & $\begin{array}{c}0.490 \\
(0.361)\end{array}$ & $\begin{array}{l}0.878^{*} \\
(0.532)\end{array}$ & $\begin{array}{c}0.412 \\
(0.611)\end{array}$ & $\begin{array}{c}0.903 \\
(0.693)\end{array}$ & $\begin{array}{c}0.860 \\
(0.761)\end{array}$ \\
\hline \multicolumn{11}{|l|}{ Borrower Characteristics } \\
\hline Profitability & $\begin{array}{c}-2.464 * * * \\
(0.899)\end{array}$ & $\begin{array}{l}-2.686^{*} \\
(1.418)\end{array}$ & $\begin{array}{l}-3.438 * \\
(1.840)\end{array}$ & $\begin{array}{l}-4.315^{*} \\
(2.339)\end{array}$ & $\begin{array}{l}-3.480 \\
(2.761)\end{array}$ & $\begin{array}{c}-3.541 * * \\
(1.617)\end{array}$ & $\begin{array}{c}-3.532 * \\
(1.958)\end{array}$ & $\begin{array}{c}-4.456^{* * *} \\
(2.254)\end{array}$ & $\begin{array}{c}-5.385^{* *} \\
(2.445)\end{array}$ & $\begin{array}{l}-2.193 \\
(2.675)\end{array}$ \\
\hline Current Ratio & $\begin{array}{c}-0.074 \\
(0.104)\end{array}$ & $\begin{array}{l}-0.139 \\
(0.178)\end{array}$ & $\begin{array}{l}-0.348 \\
(0.228)\end{array}$ & $\begin{array}{c}-0.578 * * \\
(0.275)\end{array}$ & $\begin{array}{c}-0.817 * * \\
(0.318)\end{array}$ & $\begin{array}{c}0.382 * * \\
(0.177)\end{array}$ & $\begin{array}{c}0.595^{* * *} \\
(0.260)\end{array}$ & $\begin{array}{c}0.358 \\
(0.261)\end{array}$ & $\begin{array}{c}0.166 \\
(0.294)\end{array}$ & $\begin{array}{c}-0.097 \\
(0.314)\end{array}$ \\
\hline Leverage & $\begin{array}{c}-0.146^{* * * *} \\
(0.007)\end{array}$ & $\begin{array}{c}-0.258^{* * * *} \\
(0.012)\end{array}$ & $\begin{array}{c}-0.345^{* * *} \\
(0.016)\end{array}$ & $\begin{array}{c}-0.409 * * * \\
(0.020)\end{array}$ & $\begin{array}{c}-0.472 * * * \\
(0.023)\end{array}$ & $\begin{array}{c}-0.382 * * * \\
(0.013)\end{array}$ & $\begin{array}{c}-0.674 * * * \\
(0.020)\end{array}$ & $\begin{array}{c}-0.885 * * * \\
(0.021)\end{array}$ & $\begin{array}{c}-1.016^{* * *} \\
(0.021)\end{array}$ & $\begin{array}{c}-1.114 * * * \\
(0.023)\end{array}$ \\
\hline Coverage & $\begin{array}{c}0.004 \\
(0.003)\end{array}$ & $\begin{array}{c}0.006 \\
(0.006)\end{array}$ & $\begin{array}{c}0.005 \\
(0.007)\end{array}$ & $\begin{array}{c}0.010 \\
(0.008)\end{array}$ & $\begin{array}{c}0.013 \\
(0.009)\end{array}$ & $\begin{array}{c}0.010 * * \\
(0.005)\end{array}$ & $\begin{array}{c}0.015^{* *} \\
(0.006)\end{array}$ & $\begin{array}{c}0.012 \\
(0.008)\end{array}$ & $\begin{array}{c}0.016^{* *} \\
(0.008)\end{array}$ & $\begin{array}{c}0.021 * * \\
(0.009)\end{array}$ \\
\hline 5 year Profit Trend & $\begin{array}{c}0.000 \\
(0.037)\end{array}$ & $\begin{array}{c}0.011 \\
(0.060)\end{array}$ & $\begin{array}{c}0.066 \\
(0.076)\end{array}$ & $\begin{array}{l}0.141^{*} \\
(0.084)\end{array}$ & $\begin{array}{c}0.148 \\
(0.095)\end{array}$ & $\begin{array}{c}-0.105^{* *} \\
(0.044)\end{array}$ & $\begin{array}{c}-0.164 * * * \\
(0.062)\end{array}$ & $\begin{array}{c}-0.164 * * \\
(0.066)\end{array}$ & $\begin{array}{l}-0.118^{*} \\
(0.064)\end{array}$ & $\begin{array}{c}-0.140 * * \\
(0.068)\end{array}$ \\
\hline Market to Book & $\begin{array}{c}-0.612 * * * \\
(0.115)\end{array}$ & $\begin{array}{c}-0.754 * * * \\
(0.195)\end{array}$ & $\begin{array}{c}-0.741 * * * \\
(0.242)\end{array}$ & $\begin{array}{c}-0.758 * * * \\
(0.288)\end{array}$ & $\begin{array}{c}-0.684 * *) \\
(0.339)\end{array}$ & $\begin{array}{c}-1.209^{* * *} * \\
(0.180)\end{array}$ & $\begin{array}{c}-1.287 * * * \\
(0.277)\end{array}$ & $\begin{array}{c}-1.075^{* * *} * \\
(0.315)\end{array}$ & $\begin{array}{c}-0.998 * * * \\
(0.324)\end{array}$ & $\begin{array}{c}-1.094 * * * \\
(0.300)\end{array}$ \\
\hline Log (Total Assets) & $\begin{array}{c}0.220 * * * \\
(0.074)\end{array}$ & $\begin{array}{c}0.467 * * * \\
(0.132)\end{array}$ & $\begin{array}{c}0.808 * * * \\
(0.181)\end{array}$ & $\begin{array}{c}1.059 * * * \\
(0.226)\end{array}$ & $\begin{array}{c}1.283 * * * \\
(0.270)\end{array}$ & $\begin{array}{c}0.096 \\
(0.307)\end{array}$ & $\begin{array}{c}0.815 \\
(0.511)\end{array}$ & $\begin{array}{c}1.762 * * * \\
(0.611)\end{array}$ & $\begin{array}{c}2.106 * * * \\
(0.654)\end{array}$ & $\begin{array}{c}2.339 * * * \\
(0.657)\end{array}$ \\
\hline Constant & $\begin{array}{c}10.737 * * * \\
(0.982)\end{array}$ & $\begin{array}{c}18.995^{* * * *} \\
(1.619)\end{array}$ & $\begin{array}{c}22.674 * * * * \\
(2.137) \\
\end{array}$ & $\begin{array}{c}24.940 * * * \\
(2.637) \\
\end{array}$ & $\begin{array}{c}25.465^{* * * *} \\
(3.063)\end{array}$ & $\begin{array}{c}8.967 * * * \\
(2.527) \\
\end{array}$ & $\begin{array}{c}15.693 * * * \\
(3.735) \\
\end{array}$ & $\begin{array}{c}88.934 * * * \\
(3.173) \\
\end{array}$ & $\begin{array}{c}60.664 * * * \\
(2.138) \\
\end{array}$ & $\begin{array}{c}57.649 * * * \\
(2.815) \\
\end{array}$ \\
\hline Borrower Fixed Effects & NO & NO & NO & NO & NO & YES & YES & YES & YES & YES \\
\hline Year Fixed Effects & YES & YES & YES & YES & YES & YES & YES & YES & YES & YES \\
\hline Industry Fixed Effects & YES & YES & YES & YES & YES & YES & YES & YES & YES & YES \\
\hline Rating Fixed Effects & YES & YES & YES & YES & YES & YES & YES & YES & YES & YES \\
\hline Number of Observations & 15,002 & 13,572 & 12,194 & 10,886 & 9,628 & 15,002 & 13,572 & 12,194 & 10,886 & 9,628 \\
\hline $\mathrm{R}^{2}$ & 0.092 & 0.143 & 0.176 & 0.201 & 0.225 & 0.273 & 0.441 & 0.557 & 0.644 & 0.714 \\
\hline
\end{tabular}




\section{Addition to Table IV continued \\ Dynamic Loan Contracting Following Covenant Violations in the Prior Loan - Alternative Explanations - Credit Risk}

\begin{tabular}{|c|c|c|}
\hline Panel E: Loss Making Quarters & (1) & $(2)$ \\
\hline Dependent Variable & \multicolumn{2}{|c|}{ Number of Loss Making Quarters } \\
\hline Regression Methodology & OLS & OLS \\
\hline Covenant Violation & $\begin{array}{c}0.064 \\
(0.096)\end{array}$ & $\begin{array}{c}0.101 \\
(0.089)\end{array}$ \\
\hline \multicolumn{3}{|l|}{ Borrower Characteristics } \\
\hline Profitability & $\begin{array}{c}-4.953 * * * \\
(0.701)\end{array}$ & $\begin{array}{c}-6.054 * * * \\
(0.677)\end{array}$ \\
\hline Current Ratio & $\begin{array}{c}0.088^{* *} \\
(0.042)\end{array}$ & $\begin{array}{c}0.095 * * \\
(0.039)\end{array}$ \\
\hline Leverage & $\begin{array}{c}0.001 \\
(0.003)\end{array}$ & $\begin{array}{l}-0.384 \\
(0.345)\end{array}$ \\
\hline Coverage & $\begin{array}{c}-0.006^{* * * *} \\
(0.001)\end{array}$ & $\begin{array}{c}-0.003 * * * \\
(0.001)\end{array}$ \\
\hline 5 year Profit Trend & $\begin{array}{l}-0.015 \\
(0.009)\end{array}$ & $\begin{array}{l}-0.011 \\
(0.008)\end{array}$ \\
\hline Market to Book & $\begin{array}{c}0.138^{* * *} \\
(0.061)\end{array}$ & $\begin{array}{c}-0.113 * * \\
(0.051)\end{array}$ \\
\hline Log (Total Assets) & $\begin{array}{l}-0.000 \\
(0.028)\end{array}$ & $\begin{array}{c}0.280 * * * \\
(0.077)\end{array}$ \\
\hline Constant & $\begin{array}{l}1.083^{* *} \\
(0.436) \\
\end{array}$ & $\begin{array}{c}2.163 * * * \\
(0.586)\end{array}$ \\
\hline Borrower Fixed Effects & NO & YES \\
\hline Year Fixed Effects & YES & YES \\
\hline Industry Fixed Effects & YES & YES \\
\hline Rating Fixed Effects & YES & YES \\
\hline Number of Observations & 16,150 & 16,150 \\
\hline $\mathrm{R}^{2}$ & 0.165 & 0.483 \\
\hline
\end{tabular}




\section{Addition to Table VI \\ Dynamic Loan Contracting Following Covenant Violations in the Prior Loan - Alternative Explanations - Change in CEO}

The table reports descriptive statistics of changes in CEO data (Panel A) as well as results from multivariate regressions of different dependent variables. These are the All-in-Spread-Drawn (Panel B), the number of financial covenants (Panel C), the average distance to covenant violation (DCV) (Panel D) and the DCV (Panel E). Results for the contract intensity are not reported due to insufficient observations. Prior covenant violation is a dummy variable equal to one if the borrower violated a financial covenant in the prior loan contract. The change in CEO data is derived from ExecuComp and amended with the reason why the CEO left the firm from Eisfeldt and Kuhnen (2013) available at Andrea L. Eisfeldt's personal website for the period 1992 to 2006. Panel A shows the number and percentage of changes in CEO by the reason why the CEO left the firm using only the classifications from ExecuComp over 1996 to 2010 in column (1), using only the classifications from Eisfeldt and Kuhnen (2013) over 1996 to 2006 in column (2), and using the classifications from Eisfeldt and Kuhnen (2013) over 1996 to 2006 and the classifications from ExecuComp from 2007 to 2010 in column (3). All regressions include the control variables from Table III described in Appendix 1. Standard errors shown in parentheses are robust to heteroscedasticity and clustered at the firm level. The statistical significance of results is indicated by $*=10 \%$ level, $* *=5 \%$ level and $* * *$ $=1 \%$ level.

\begin{tabular}{lccc}
\hline \hline Panel A & (1) & (2) & (3) \\
\hline Data Source & $\begin{array}{c}\text { Only } \\
\text { ExecuComp }\end{array}$ & $\begin{array}{c}\text { Only } \\
\text { Eisfeldt and Kuhnen (2013) }\end{array}$ & $\begin{array}{c}\text { Eisfeldt and Kuhnen (2013) } \\
\text { and ExecuComp }\end{array}$ \\
\hline Resigned / Forced Turnover & 99 & 61 & 93 \\
& $18.929 \%$ & $15.762 \%$ & $17.782 \%$ \\
Retired & 179 & 111 & 157 \\
& $34.226 \%$ & $28.682 \%$ & $30.019 \%$ \\
Unknown /Unclassified & 245 & 215 & 273 \\
Turnover & $46.845 \%$ & $55.556 \%$ & $52.199 \%$ \\
Total Number of CEO & 523 & 387 & 523 \\
Changes & & & 59 \\
\hline \hline
\end{tabular}




\section{NOT FOR PUBLICATION}

Addition to Table VI

Dynamic Loan Contracting Following Covenant Violations in the Prior Loan - Alternative Explanations - Managerial Agency Problems

\begin{tabular}{|c|c|c|c|c|c|c|c|}
\hline \multirow{3}{*}{$\begin{array}{l}\text { Panel B: AISD } \\
\text { Data Source } \\
\text { Regression Methodology }\end{array}$} & (1) & (2) & (3) & (4) & (5) & \multirow{2}{*}{\multicolumn{2}{|c|}{$\begin{array}{c}\mathbf{( 6 )} \quad \mathbf{( 7 )} \\
\text { Eisfeldt and Kuhnen } \\
(2013) \\
\text { and ExecuComp }\end{array}$}} \\
\hline & \multicolumn{3}{|c|}{ Only ExecuComp } & \multicolumn{2}{|c|}{ Only ExecuComp } & & \\
\hline & OLS & OLS & OLS & OLS & OLS & OLS & OLS \\
\hline Prior Covenant Violation & $\begin{array}{c}13.926 * * * \\
(4.381)\end{array}$ & $\begin{array}{c}13.894 * * * \\
(4.363)\end{array}$ & $\begin{array}{l}17.142 * * * \\
(5.134)\end{array}$ & $\begin{array}{l}13.911 * * * \\
(4.352)\end{array}$ & $\begin{array}{l}17.325^{* * * *} \\
(5.142)\end{array}$ & $\begin{array}{c}13.945^{* * * *} \\
(4.336)\end{array}$ & $\begin{array}{l}17.199 * * * \\
(5.139)\end{array}$ \\
\hline Change in CEO & & $\begin{array}{l}-0.729 \\
(4.536)\end{array}$ & $\begin{array}{c}5.261 \\
(5.543)\end{array}$ & & & & \\
\hline Prior Covenant Violation $*$ & & & -12.253 & & & & \\
\hline Change in CEO & & & $(8.566)$ & & & & \\
\hline Change in CEO - Resigned & & & & $\begin{array}{c}12.142 \\
(10.558)\end{array}$ & $\begin{array}{c}20.933 \\
(13.917)\end{array}$ & $\begin{array}{l}16.192 * \\
(8.724)\end{array}$ & $\begin{array}{l}30.450 * * \\
(12.210)\end{array}$ \\
\hline Change in CEO - Retired & & & & $\begin{array}{l}-3.031 \\
(6.137)\end{array}$ & $\begin{array}{c}2.421 \\
(7.365)\end{array}$ & $\begin{array}{l}-1.060 \\
(7.315)\end{array}$ & $\begin{array}{c}1.599 \\
(8.563)\end{array}$ \\
\hline Change in CEO - Unknown & & & & $\begin{array}{l}-4.404 \\
(5.899)\end{array}$ & $\begin{array}{c}1.489 \\
(7.395)\end{array}$ & $\begin{array}{l}-6.065 \\
(5.827)\end{array}$ & $\begin{array}{l}-1.042 \\
(6.885)\end{array}$ \\
\hline Prior Covenant Violation * & & & & & -16.605 & & -28.662 \\
\hline Change in CEO - Resigned & & & & & $(18.389)$ & & $(19.025)$ \\
\hline Prior Covenant Violation $*$ & & & & & -13.052 & & -5.805 \\
\hline Change in CEO - Retired & & & & & $(12.469)$ & & $(15.344)$ \\
\hline Prior Covenant Violation * & & & & & -11.159 & & -9.709 \\
\hline Change in CEO - Unknown & & & & & $(11.516)$ & & $(10.252)$ \\
\hline Control Variables & YES & YES & YES & YES & YES & YES & YES \\
\hline Number of Observations & 1,948 & 1,948 & 1,948 & 1,948 & 1,948 & 1,948 & 1,948 \\
\hline $\mathrm{R}^{2}$ & 0.709 & 0.709 & 0.709 & 0.710 & 0.710 & 0.710 & 0.711 \\
\hline Panel C: Covenant Number & (1) & (2) & (3) & (4) & (5) & $\overline{(26)}$ & (7) \\
\hline Data Source & & ly ExecuCo & & Only Ex & cuComp & $\begin{array}{r}\text { Eisfeldt a } \\
\qquad(2 \\
\text { and Ex }\end{array}$ & $\begin{array}{l}\text { d Kuhnen } \\
\text { 13) } \\
\text { cuComp }\end{array}$ \\
\hline Regression Methodology & $\begin{array}{l}\text { Ordered } \\
\text { Logit }\end{array}$ & $\begin{array}{c}\text { Ordered } \\
\text { Logit }\end{array}$ & $\begin{array}{l}\text { Ordered } \\
\text { Logit }\end{array}$ & $\begin{array}{l}\text { Ordered } \\
\text { Logit }\end{array}$ & $\begin{array}{l}\text { Ordered } \\
\text { Logit }\end{array}$ & $\begin{array}{l}\text { Ordered } \\
\text { Logit }\end{array}$ & $\begin{array}{l}\text { Ordered } \\
\text { Logit }\end{array}$ \\
\hline Prior Covenant Violation & $\begin{array}{c}0.371 * * * \\
(0.126)\end{array}$ & $\begin{array}{c}0.370 * * * \\
(0.126)\end{array}$ & $\begin{array}{c}0.390 * * * \\
(0.149)\end{array}$ & $\begin{array}{c}0.365^{* * *} \\
(0.126)\end{array}$ & $\begin{array}{c}0.388 * * * \\
(0.149)\end{array}$ & $\begin{array}{c}0.366 * * * \\
(0.127)\end{array}$ & $\begin{array}{c}0.386 * * * \\
(0.150)\end{array}$ \\
\hline Change in CEO & & $\begin{array}{l}-0.042 \\
(0.129)\end{array}$ & $\begin{array}{l}-0.003 \\
(0.167)\end{array}$ & & & & \\
\hline Prior Covenant Violation * & & & -0.080 & & & & \\
\hline Change in CEO & & & $(0.280)$ & & & & \\
\hline Change in CEO - Resigned & & & & $\begin{array}{l}-0.340 \\
(0.291)\end{array}$ & $\begin{array}{l}-0.125 \\
(0.338)\end{array}$ & $\begin{array}{l}-0.341 \\
(0.312)\end{array}$ & $\begin{array}{l}-0.185 \\
(0.351)\end{array}$ \\
\hline Change in CEO - Retired & & & & $\begin{array}{c}0.004 \\
(0.203)\end{array}$ & $\begin{array}{l}-0.166 \\
(0.280)\end{array}$ & $\begin{array}{c}0.190 \\
(0.212)\end{array}$ & $\begin{array}{c}0.384 \\
(0.270)\end{array}$ \\
\hline Change in CEO - Unknown & & & & $\begin{array}{c}0.051 \\
(0.170)\end{array}$ & $\begin{array}{c}0.198 \\
(0.224)\end{array}$ & $\begin{array}{l}-0.071 \\
(0.168)\end{array}$ & $\begin{array}{l}-0.165 \\
(0.231)\end{array}$ \\
\hline Prior Covenant Violation $*$ & & & & & -0.411 & & -0.330 \\
\hline Change in CEO - Resigned & & & & & $(0.566)$ & & $(0.639)$ \\
\hline Prior Covenant Violation $*$ & & & & & 0.387 & & -0.415 \\
\hline Change in CEO - Retired & & & & & $(0.414)$ & & $(0.454)$ \\
\hline Prior Covenant Violation * & & & & & -0.271 & & 0.176 \\
\hline Change in CEO - Unknown & & & & & $(0.350)$ & & $(0.339)$ \\
\hline Control Variables & YES & YES & YES & YES & YES & YES & YES \\
\hline Number of Observations & 1,904 & 1,904 & 1,904 & 1,904 & 1,904 & 1,904 & 1,904 \\
\hline $\mathrm{R}^{2}$ & 0.188 & 0.188 & 0.188 & 0.189 & 0.189 & 0.189 & 0.189 \\
\hline
\end{tabular}


Addition to Table VI continued

Dynamic Loan Contracting Following Covenant Violations in the Prior Loan - Alternative Explanations - Managerial Agency Problems

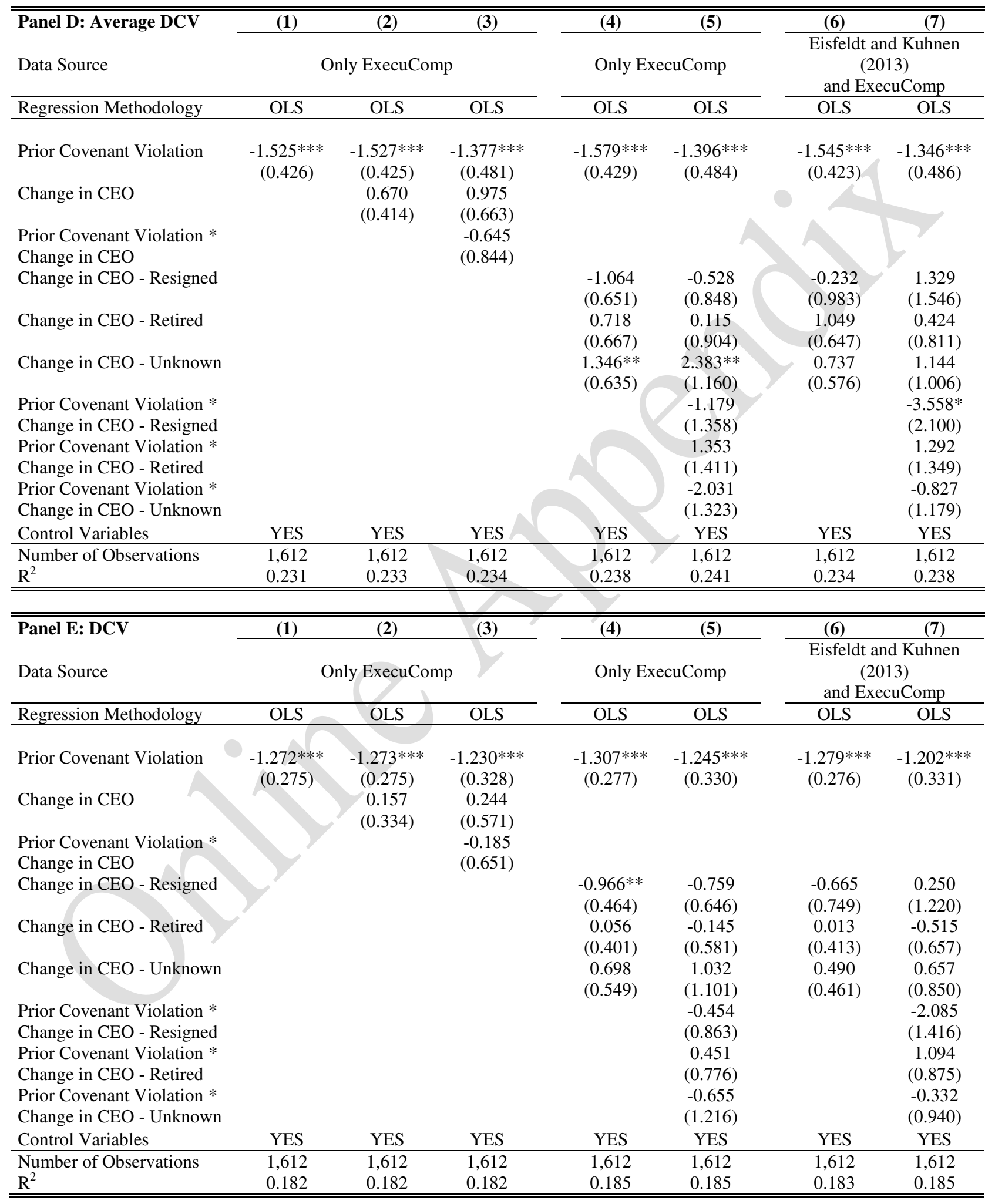




\section{Addition to Table IX}

\section{Profitability-Based versus Capital-Based Covenants and Dynamic Loan Contracting}

The table reports results from the analysis of various covenant types. These are categorized into profitability-based and capital-based covenants following partly Christensen and Nikolaev (2012). Profitability Covenants are Debt to EBITDA, Debt Service Coverage Ratio, EBITDA, Fixed Charge Coverage Ratio, Interest Coverage Ratio, Senior Debt to EBITDA. Capital Covenants are Asset Coverage Ratio, Current Ratio, Debt to Capitalization, Debt to Net Worth, Net Worth, Quick Ratio, Senior Debt to Capitalization, Senior Debt to Net Worth, Tangible Net Worth, Working Capital. Violation Profitability Covenant indicates violations of EBITDA, Debt to EBITDA, Debt Service Coverage Ratio, Fixed Charge Coverage Ratio, Interest Coverage Ratio or Senior Debt to EBITDA covenants in the prior loan; Violation Leverage Covenant is defined accordingly and includes Debt to Capitalization and Senior Debt to Capitalization covenants; Violation Net Worth Covenant includes Debt to Net Worth, Net Worth, Senior Debt to Net Worth and Tangible Net Worth covenants; Violation Short-term Covenant includes Asset Coverage Ratio, Current Ratio, Quick Ratio, Working Capital, Cash and Cash Equivalents covenants. Note that Cash and Cash Equivalents are neither classified as profitability nor as capital covenants in Christensen and Nikolaev (2012), but are included in our classification of Short-term Covenants. Panel A shows the percentage of contracts including a (1) Profitability covenant, (2) Capital Covenant, (3) Leverage Covenant, (4) Net Worth Covenant and (5) Short-term Covenant given that the covenant type mentioned in the first column was violated in the prior loan. Panel B reports the results from regressions relating in models (1) to (4) and (7) to (12) an indicator variable which is one when a profitability covenant, capital covenant, leverage covenant, net worth covenant or short term covenant is included in the new loan to the type of prior covenant violation. The percentage of profitability-based covenants is calculated as profitability-based covenants over profitability-based plus capital-based covenants. All variables are described in Appendix 1. In Panels B and C, Model (5) "Secured" is excluded as it is part of the dependent variable. Standard errors shown in parentheses are robust to heteroscedasticity and clustered at the firm level. The statistical significance of results is indicated by $*=10 \%$ level, $* *=5 \%$ level and $* * *=1 \%$ level.

\begin{tabular}{|c|c|c|c|c|c|}
\hline $\begin{array}{l}\text { Panel A: Percentage of Contracts } \\
\text { Including a Covenant Type } \\
\text { conditional on having violated a } \\
\text { Specific Covenant Type in the Prior } \\
\text { Contract }\end{array}$ & (1) & (2) & (3) & (4) & (5) \\
\hline 0 & $\begin{array}{l}\text { Profitability } \\
\text { Covenant }\end{array}$ & $\begin{array}{c}\text { Capital } \\
\text { Covenant }\end{array}$ & $\begin{array}{l}\text { Leverage } \\
\text { Covenant }\end{array}$ & $\begin{array}{l}\text { Net Worth } \\
\text { Covenant }\end{array}$ & $\begin{array}{c}\text { Short-term } \\
\text { Covenant }\end{array}$ \\
\hline $\begin{array}{l}\text { Prior Covenant Violation } \\
\text { Violation Profitability Covenant }\end{array}$ & $96.49 \%$ & $40.62 \%$ & $7.58 \%$ & $29.57 \%$ & $48.31 \%$ \\
\hline $\begin{array}{l}\text { Violation Capital Covenant } \\
\text { Violation Leverage Covenant } \\
\text { Violation Net Worth Covenant } \\
\text { Violation Short-term Covenant }\end{array}$ & $\begin{array}{l}89.86 \% \\
80.39 \% \\
92.39 \% \\
91.56 \%\end{array}$ & $\begin{array}{l}68.28 \% \\
71.08 \% \\
63.04 \% \\
77.92 \%\end{array}$ & $\begin{array}{l}23.46 \% \\
55.14 \% \\
13.28 \% \\
16.56 \%\end{array}$ & $\begin{array}{l}40.90 \% \\
26.17 \% \\
53.39 \% \\
31.29 \%\end{array}$ & $\begin{array}{l}48.15 \% \\
46.26 \% \\
39.84 \% \\
65.64 \%\end{array}$ \\
\hline
\end{tabular}




\section{NOT FOR PUBLICATION}

\section{Addition to Table IX continued}

\section{Profitability-Based versus Capital-Based Covenants and Dynamic Loan Contracting}

\begin{tabular}{|c|c|c|c|c|c|c|c|c|c|c|c|c|}
\hline $\begin{array}{l}\text { Panel B: Including } \\
\text { Profitability or Capital } \\
\text { Covenants in the Subsequent } \\
\text { Contract }\end{array}$ & (1) & (2) & (3) & (4) & (5) & (6) & (7) & (8) & (9) & (10) & (11) & (12) \\
\hline & $\begin{array}{c}\text { Profitability } \\
\text { Covenant }\end{array}$ & $\begin{array}{c}\text { Profitability } \\
\text { Covenant }\end{array}$ & $\begin{array}{c}\text { Capital } \\
\text { Covenant }\end{array}$ & $\begin{array}{c}\text { Capital } \\
\text { Covenant }\end{array}$ & $\begin{array}{c}\text { Percentage } \\
\text { of } \\
\text { Profitability } \\
\text { Covenants } \\
\end{array}$ & $\begin{array}{c}\text { Percentage } \\
\text { of } \\
\text { Profitability } \\
\text { Covenants } \\
\end{array}$ & $\begin{array}{l}\text { Leverage } \\
\text { Covenant }\end{array}$ & $\begin{array}{l}\text { Leverage } \\
\text { Covenant }\end{array}$ & $\begin{array}{c}\text { Net } \\
\text { Worth } \\
\text { Covenant }\end{array}$ & $\begin{array}{c}\text { Net } \\
\text { Worth } \\
\text { Covenant }\end{array}$ & $\begin{array}{l}\text { Short- } \\
\text { term } \\
\text { Covenant }\end{array}$ & $\begin{array}{c}\text { Short- } \\
\text { term } \\
\text { Covenant }\end{array}$ \\
\hline Regression Methodology & Logit & Logit & Logit & Logit & OLS & OLS & Logit & Logit & Logit & Logit & Logit & Logit \\
\hline Violation Profitability Covenant & $\begin{array}{c}1.194 * * * \\
(0.272)\end{array}$ & $\begin{array}{c}1.237 * * * \\
(0.275)\end{array}$ & $\begin{array}{c}-0.638 * * * \\
(0.149)\end{array}$ & $\begin{array}{c}-0.612 * * * \\
(0.149)\end{array}$ & $\begin{array}{c}0.107 * * * \\
(0.018)\end{array}$ & $\begin{array}{c}0.107 * * * \\
(0.018)\end{array}$ & $\begin{array}{c}-1.228 * * * \\
(0.217)\end{array}$ & $\begin{array}{c}-1.298 * * * \\
(0.234)\end{array}$ & $\begin{array}{l}-0.100 \\
(0.155)\end{array}$ & $\begin{array}{l}-0.211 \\
(0.162)\end{array}$ & $\begin{array}{l}-0.249 * \\
(0.138)\end{array}$ & $\begin{array}{l}-0.215 \\
(0.141)\end{array}$ \\
\hline Violation Capital Covenant & $\begin{array}{c}-0.203 \\
(0.280)\end{array}$ & & $\begin{array}{c}1.170 * * * \\
(0.175)\end{array}$ & & $\begin{array}{c}-0.084 * * * \\
(0.019)\end{array}$ & & $\begin{array}{c}1.230 * * * \\
(0.216)\end{array}$ & & $\begin{array}{l}0.354 * \\
(0.192)\end{array}$ & & $\begin{array}{l}-0.128 \\
(0.155)\end{array}$ & \\
\hline Violation Leverage Covenant & & $\begin{array}{c}-0.244 \\
(0.389)\end{array}$ & & $\begin{array}{c}1.081 * * * \\
(0.332)\end{array}$ & & $(0.036)$ & & $\begin{array}{c}2.728 * * * \\
(0.313)\end{array}$ & & $\begin{array}{c}-0.413 \\
(0.396)\end{array}$ & & $\begin{array}{c}-0.405 \\
(0.258)\end{array}$ \\
\hline Violation Net Worth Covenant & & $\begin{array}{c}-0.510 \\
(0.342)\end{array}$ & & $\begin{array}{c}0.890 * * * \\
(0.204)\end{array}$ & & $\begin{array}{c}-0.070 * * * \\
(0.022)\end{array}$ & & $\begin{array}{c}0.259 \\
(0.277)\end{array}$ & & $\begin{array}{c}1.102 * * * \\
(0.230)\end{array}$ & & $\begin{array}{c}-0.412 * * \\
(0.194)\end{array}$ \\
\hline Violation Short-term Covenant & & $\begin{array}{l}-0.047 \\
(0.501)\end{array}$ & & $\begin{array}{l}0.795^{*} \\
(0.412)\end{array}$ & & $\begin{array}{c}-0.072 * * \\
(0.035)\end{array}$ & & $\begin{array}{c}0.422 \\
(0.410)\end{array}$ & & $\begin{array}{c}-0.726 * * \\
(0.333)\end{array}$ & & $\begin{array}{c}0.938 * * * \\
(0.317)\end{array}$ \\
\hline Loan Characteristics & YES & YES & YES & YES & YES & YES & YES & YES & YES & YES & YES & YES \\
\hline Borrower Characteristics & YES & YES & YES & YES & YES & YES & YES & YES & YES & YES & YES & YES \\
\hline Year Fixed Effects & YES & YES & YES & YES & YES & YES & YES & YES & YES & YES & YES & YES \\
\hline Industry Fixed Effects & YES & YES & YES & YES & YES & YES & YES & YES & YES & YES & YES & YES \\
\hline Rating Fixed Effects & YES & YES & YES & YES & YES & YES & YES & YES & YES & YES & YES & YES \\
\hline Loan Type Fixed Effects & YES & YES & YES & YES & YES & YES & YES & YES & YES & YES & YES & YES \\
\hline Loan Purpose Fixed Effects & YES & YES & YES & YES & YES & YES & YES & YES & YES & YES & YES & YES \\
\hline Number of Observations & 2497 & 2497 & 2497 & 2497 & 2693 & 2693 & 2,563 & 2,563 & 2,680 & 2,680 & 2,706 & 2,706 \\
\hline $\mathrm{R}^{2}$ & 0.365 & 0.367 & 0.236 & 0.232 & 0.343 & 0.344 & 0.293 & 0.332 & 0.183 & 0.203 & 0.112 & 0.121 \\
\hline
\end{tabular}




\section{NOT FOR PUBLICATION}

\section{Addition to Table XI}

\section{The Dynamic Effect of Past Covenant Violations on Loan Contract Terms}

The table reports results from multivariate regressions of various price and non-price loan contract terms on covenant violations and control variables. These are the (1) All-in-Spread-Drawn, (2) the number of financial covenants, (3) the average distance to covenant violation (DCV), (4) the DCV, and (5) the contract intensity as well as in Panel B the percentage of profitability covenants. The regressions segregate the sample into different time periods reflecting the sequence of loans of individual borrowers. Second (Third) Loan is an indicator variable for the second (third) loan, the first loan is the base case. "Second Loan, Violation in First Loan" (Third Loan, Violation in Second Loan) is an indicator variable equal to 1 if the borrower has violated a covenant in the first (second) loan and obtains the second (third) loan. In Panel A these indicator variables are replaced by the number of covenants violated in the second (third) loan contract. In Panel B, these indicator variables are also replaced by the type of covenant violated in the second (third) loan contract. All variables are described in Appendix 1. In Models (5) and (10) "Secured" is excluded as it is part of the dependent variable. Standard errors shown in parentheses are robust to heteroscedasticity and clustered at the firm level. The statistical significance of results is indicated by $*=10 \%$ level, $* *=5 \%$ level and $* * *=1 \%$ level.

\begin{tabular}{|c|c|c|c|c|c|}
\hline Panel A & (1) & $(2)$ & (3) & (4) & $(5)$ \\
\hline Dependent Variable & AISD & $\begin{array}{l}\text { Covenant } \\
\text { Number }\end{array}$ & Average DCV & DCV & $\begin{array}{l}\text { Contract } \\
\text { Intensity }\end{array}$ \\
\hline Regression Methodology & OLS & Ordered Logit & OLS & OLS & Ordered Logit \\
\hline Second Loan & $\begin{array}{c}-7.877^{*} \\
(4.114)\end{array}$ & $\begin{array}{c}-0.233 * * \\
(0.115)\end{array}$ & $\begin{array}{c}1.734 * * * \\
(0.448)\end{array}$ & $\begin{array}{c}0.966 * * * \\
(0.376)\end{array}$ & $\begin{array}{c}0.065 \\
(0.263)\end{array}$ \\
\hline \multicolumn{6}{|l|}{ Second Loan, Violation in First Loan } \\
\hline 1 Covenant Violated & $\begin{array}{c}2.232 \\
(5.639)\end{array}$ & $\begin{array}{c}0.213 \\
(0.173)\end{array}$ & $\begin{array}{c}-1.872 * * * \\
(0.495)\end{array}$ & $\begin{array}{c}-1.046 * * * \\
(0.443)\end{array}$ & $\begin{array}{c}0.158 \\
(0.360)\end{array}$ \\
\hline 2 Covenants Violated & $\begin{array}{c}18.262 * * \\
(8.405)\end{array}$ & $\begin{array}{c}-0.011 \\
(0.188)\end{array}$ & $\begin{array}{c}-1.373 * * \\
(0.638)\end{array}$ & $\begin{array}{c}-1.128 * * * \\
(0.361)\end{array}$ & $\begin{array}{c}0.154 \\
(0.378)\end{array}$ \\
\hline 3 Covenants Violated & $\begin{array}{c}35.055^{* * *} * \\
(10.186)\end{array}$ & $\begin{array}{c}0.630 * * \\
(0.247)\end{array}$ & $\begin{array}{c}-2.180 * * * \\
(0.510)\end{array}$ & $\begin{array}{c}-1.149 * * * \\
(0.382)\end{array}$ & $\begin{array}{c}0.493 \\
(0.443)\end{array}$ \\
\hline 4 or more Covenants Violated & $\begin{array}{c}39.927 * * * \\
(12.286)\end{array}$ & $\begin{array}{c}1.604 * * * \\
(0.323)\end{array}$ & $\begin{array}{c}-2.239 * * * \\
(0.543)\end{array}$ & $\begin{array}{c}-1.327 * * * \\
(0.429)\end{array}$ & $\begin{array}{l}-0.442 \\
(0.613)\end{array}$ \\
\hline Third Loan & $\begin{array}{c}-10.066^{*} \\
(5.663)\end{array}$ & $\begin{array}{l}-0.199 \\
(0.134)\end{array}$ & $\begin{array}{c}2.328 * * * \\
(0.638)\end{array}$ & $\begin{array}{c}1.598 * * * \\
(0.503)\end{array}$ & $\begin{array}{l}-0.059 \\
(0.345)\end{array}$ \\
\hline \\
\hline 1 Covenant Violated & $\begin{array}{l}-9.868 \\
(6.856)\end{array}$ & $\begin{array}{c}0.208 \\
(0.195)\end{array}$ & $\begin{array}{c}-2.081 * * * \\
(0.731)\end{array}$ & $\begin{array}{c}-1.792 * * * \\
(0.542)\end{array}$ & $\begin{array}{c}0.347 \\
(0.524)\end{array}$ \\
\hline 2 Covenants Violated & $\begin{array}{l}18.153^{*} \\
(9.601)\end{array}$ & $\begin{array}{l}0.340 \\
(0.258)\end{array}$ & $\begin{array}{c}-2.637 * * * \\
(0.708)\end{array}$ & $\begin{array}{c}-1.734 * * * \\
(0.476)\end{array}$ & $\begin{array}{c}0.167 \\
(0.456)\end{array}$ \\
\hline 3 Covenants Violated & $\begin{array}{c}24.494 * * \\
(11.174)\end{array}$ & $\begin{array}{c}0.352 \\
(0.335)\end{array}$ & $\begin{array}{c}-2.536^{* * * *} \\
(0.689)\end{array}$ & $\begin{array}{c}-1.333^{* *} \\
(0.531)\end{array}$ & $\begin{array}{l}0.164 \\
(0.503)\end{array}$ \\
\hline 4 or more Covenants Violated & $60.414 * *$ & $1.281 * * *$ & $-2.852 * * *$ & $-2.016 * * *$ & 0.711 \\
\hline (1) & $(25.128)$ & $(0.446)$ & $(0.785)$ & $(0.512)$ & $(0.784)$ \\
\hline Loan Characteristics & YES & YES & YES & YES & YES \\
\hline Borrower Characteristics & YES & YES & YES & YES & YES \\
\hline Year Fixed Effects & YES & YES & YES & YES & YES \\
\hline Industry Fixed Effects & YES & YES & YES & YES & YES \\
\hline Rating Fixed Effects & YES & YES & YES & YES & YES \\
\hline Loan Type Fixed Effects & YES & YES & YES & YES & YES \\
\hline Loan Purpose Fixed Effects & YES & YES & YES & YES & YES \\
\hline Number of Observations & 4145 & 4074 & 3472 & 3472 & 1684 \\
\hline $\mathrm{R}^{2}$ & 0.632 & 0.137 & 0.186 & 0.121 & 0.195 \\
\hline
\end{tabular}




\section{Addition to Table XI continued The Dynamic Effect of Past Covenant Violations on Loan Contract Terms}

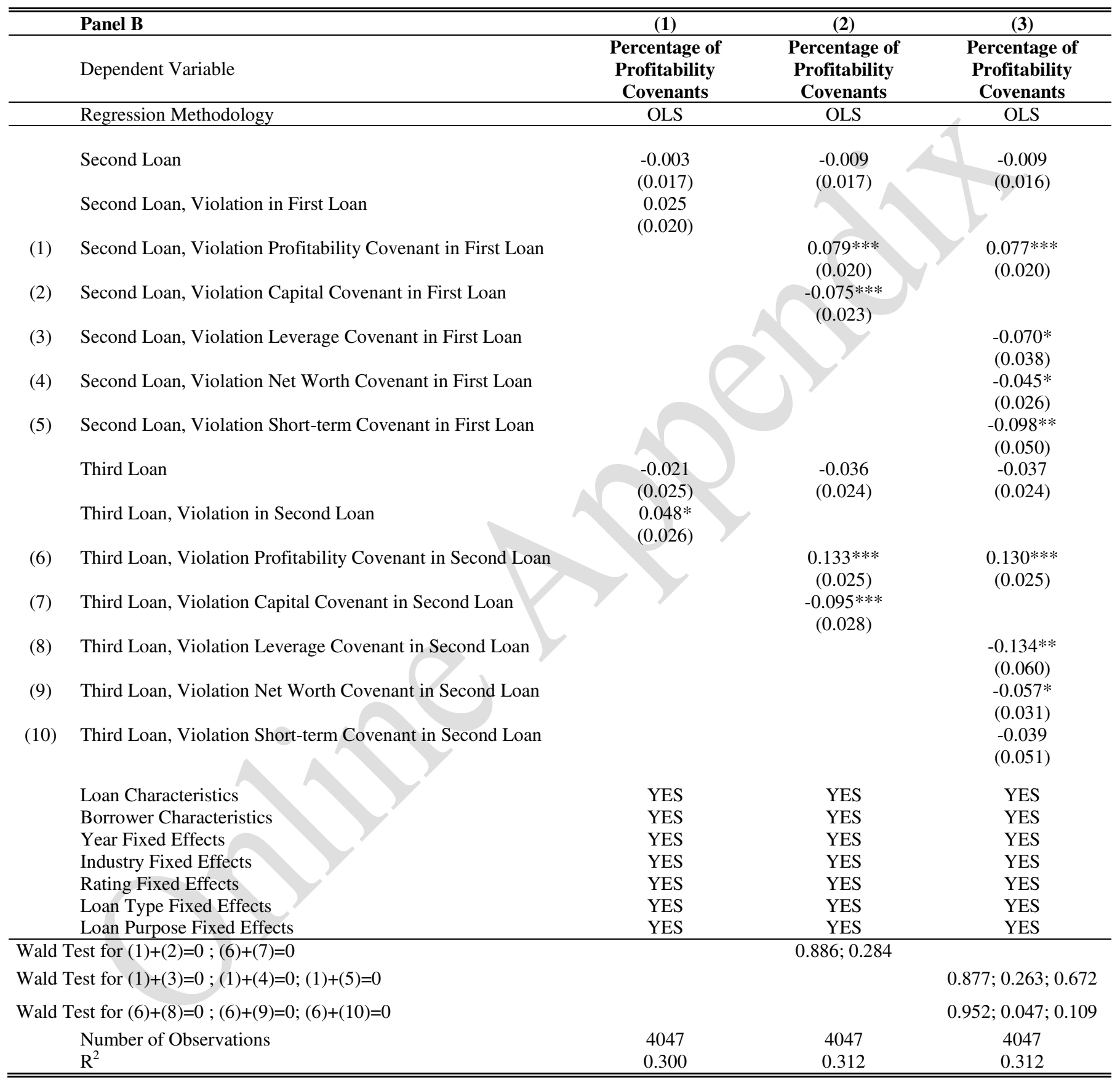

